\title{
AVALIAÇÃO DA LIBERAÇÃO DE FLÚOR DE RESINAS COMPOSTAS EM ÁGUA E EM CICLAGEM DE pH
}

Rosa Maria Viana de Bragança Garcez

Dissertação apresentada à Faculdade de Odontologia de Bauru, da Universidade de São Paulo, como parte dos requisitos para obtenção do título de Mestre em Odontologia - área de Dentística, opção Materiais Dentários

(Edição Revisada) 


\section{AVALIAÇÃO DA LIBERAÇÃO DE FLÚOR DE RESINAS COMPOSTAS EM ÁGUA E EM CICLAGEM DE pH}

\section{Rosa Maria Viana de Bragança Garcez}

Dissertação apresentada à Faculdade de Odontologia de Bauru, da Universidade de São Paulo, como parte dos requisitos para obtenção do título de Mestre em Odontologia - área de Dentística, opção Materiais Dentários

(Edição Revisada)

Orientador: Prof. Dr. Paulo Amarante de Araújo

\section{BAURU}

2001 
GARCEZ, Rosa Maria Viana de Bragança

G164a Avaliação da liberação de flúor de resinas compostas em água e em ciclagem de pH / Rosa Maria Viana de Bragança Garcez.-- Bauru, 2001. $124 \mathrm{p}$ : il.; $29,7 \mathrm{~cm}$.

Dissertação (Mestrado) -- Faculdade de Odontologia de Bauru, USP

Orientador: Prof. Dr. Paulo Amarante de Araújo

Autorizo, exclusivamente para fins acadêmicos e científicos, a reprodução total o parcial desta dissertação, por processos fotocopiadores e/ou meio eletrônico.

Assinatura do autor:

Data: 


\section{ROSA MARIA VIANA DE BRAGANÇA GARCEZ}

20 de janeiro de 1955

Aracaju-SE

1973-1976

1979

$1998-2000$

1999-2001

Associações
Nascimento

Curso de Odontologia- Universidade Federal de Sergipe.

Professora do Departamento de Odontologia da Universidade Federal de Sergipe.

Curso de Especialização em Odontologia em Saúde Coletiva no Hospital de Reabilitação de Anomalias Crânio Faciais, Universidade de São Paulo.

Curso de Pós-graduação em Odontologia, na área de Dentística, opção Materiais Dentários, em nivel de Mestrado, na Faculdade de Odontologia de Bauru, da Universidade de São Paulo.

- Associação Brasileira de Odontologia- Secção Sergipe

- Associação Brasileira de Odontologia de Promoção de Saúde

- International Association of Dental Research 
"É graça divina começar bem

Graça maior, persistir na caminhada certa

Mas, graça das graças é não desistir."

A Deus,

Que como Pai

sempre me encheu de espírito,

de amor e de luz. 


\section{Marcelo,}

Ter a alegria de uma criança,

Ter as incertezas de um jovem,

Ter a maturidade de um homem,

Tornam você único, uma pessoa especial,

que soube enfretar "desafios"

mas sempre será

"meu menino"

Obrigado. 
À minha mãe Maria,

Que soube mostrar os princípios e os valores do ser humano,

tem o meu eterno amor de filha.

À meu pai Bragança,

Que às vezes ausente, mas meu carinho de filha permite sempre dizer, minha querida Rosinha.

Aos meus irmãos Martha e Ricardo,

pelo apoio solidário e carinho desse momento,

o que nos tornam cada vez mais unidos.

À D. Leila e Dr. João (in memorian), pelo carinho que me tem como filha.

Aos cunhados e sobrinhos, Pedro Jorge, Pedrinho, Petra, Rose,

Ricardo, Rafaella, Roberto, Luciana, Isabela, Cláudia, João e

Leilinha que mesmo distantes, souberam se fazerem presentes.

À Jorge Luiz, Nem tudo foi em vão...

Desnudar o ser

Descobrir a si mesmo

Encontrar fortaleza interior adormecida Nos levam a conquistas e alegrias de valores inestimáveis 
Ao Prof. Dr. Paulo Amarante de Araújo,

que com o entusiasmo de mestre, a sabedoria e a tranqüilidade de um sábio, incentivou todos os nossos sonhos,

hoje concretizados.

Pelo seu carinho e dedicação, minha eterna gratidão. 
Aos professores

Dr. César Antunes de Freitas e Dr. Paulo Afonso Silveira Francisconi

pelo convívio e carinho, que fazem nos sentirmos em família. Obrigado

Aos professores Dr. Afrânio Bastos, Dr. João Garcez,

Dr.Fernando Vasconcelos, Dr. Lélio Fortes (in memorian), por acreditarem em mim, e me incentivarem na carreira docente,

com os ensinamentos de verdadeiros mestres.

Ao Prof. Dr. Eymar Sampaio Lopes,

pelo apoio e compreensão durante o período no HRAC.

Ao Prof. Dr. José Roberto Pereira Lauris,

pela realização da análise estatística.

À Prof. ${ }^{a}$ Dr. ${ }^{a}$ Marília Afonso Rabello Buzalaf

pela paciência e atenção de ter me conduzido na parte experimental. 
Quando amamos, temos dádivas,

Quando temos amigos, recebemos tesouros.

Aos colegas e amigos do Curso de Mestrado:

Paulo Boer, Pedro, Renatinha e Willian pelo convívio fraterno em todos os momentos que passamos juntos durante todo o curso de Mestrado... Verdadeiros guardiões!

\footnotetext{
À Linda, Fernanda e Anuska

pela grandeza da alma que as tornam especiais.

Minhas filhas...
}

À Maria Carmen, Cristiane e Élio, que se revelaram verdadeiros companheiros e amigos.

Aos meus familiares, tios, primos e amigos

que estiverem ao meu lado, compartilhando

dificuldades e vitórias.

À Ciça, seu apoio profissional e carinho me fortaleceram nessa caminhada. 
Aos colegas da dentística, Amanda, Bárbara, Celiane, Daniele,

Fábio,Júlio, Lawrence e Paulo pela união e companherismo

Amigos para sempre...

Aos colegas de curso Ana Rita, Aparício, Carla,

Fernanda Bijella, Heraldo, Henrique

e Rodrigo, pela amizade.

Aos colegas dos cursos de Diagnóstico Oral, Endodontia,

Odontologia em Saúde Coletiva, Odontopediatria, Ortodontia,

Patologia, Periodontia, Reabilitação Oral, pela alegria do convívio.

Aos funcionários do Departamento de Materiais Dentários da FOB-USP: Sandra, Alcides e Lourisvalda, pelo carinho a mim dispensado em todos esses anos...

Aos funcionários da Pós-Graduação: Giane,

Aurélio, Heloísa, Sônia e Neide, pela atenção.

Salvador e Joice, pela presteza e dedicação

À Fátima e Cisira, pela dedicação e empenho, com que realizaram a estrutura deste trabalho. 
À Faculdade de Odontologia de Bauru, da Universidade de São Paulo, representada pelo seu Diretor Prof. Dr. Aymar Pavarini e Vice-Diretor Prof. Dr. Clóvis Monteiro Bramante.

Ao Programa Institucional de Capacitação de Docentes da CAPES, pelo apoio financeiro para a realização do curso de Pós-Graduação, na pessoa da Prof. ${ }^{a}$ Neuza Maria G. Ribeiro.

A todos os professores do Curso de Pós-Graduação,

pelos ensinamentos, experiências e conhecimentos transmitidos durante o curso.

Ao Prof Dr. Mauro Grangeiro, e os que fazem o Departamento de Bioquímica, Telma, Ovídio, Gilmar e todos os seus estagiários, por transformarem o ambiente frio da pesquisa em local de paz e calor humano.

Aos funcionários da biblioteca, César, Mônica, Jane, Rita, Cybelle, Ademir Maria Helena, Célia, Ana Paula, Marcelo, Vera, Valéria, Tereza que me auxiliaram sempre, de forma prestativa e amiga. 


\section{AGRADECIMENTOS ESPECIAIS}

\section{À Alaíde e Carlinhos}

Que muito mais que amigos, verdadeiros irmãos, sempre estiveram presentes em todos os momentos, pelo otimismo e determinação.

Aos amigos Anderson, Ivana, Tânia, Fátima, Patrícia, Pacheco, Luís Carlos, Patrícia Santana, André Lucas, Alexandre, Hermenegildo, Mirabeau, Maria Helena, Derileda, Edvaldo, Denise, Karina, Mara e Ricardo pelo carinho.

Aos colegas do Centrinho,

Catherine, Tereza, Juliana, Jacqueline,

Renata, Juliana, Cristiane, Sílvia, Roosevelt e Daniele

pela convivência e pelo tempo de luta

À Celinha que como irmã, mesmo distante, com seu carinho silencioso sempre participou de todas as minhas alegrias, juntamente com sua familia 
À Universidade Federal de Sergipe, na pessoa do

Magnífico Reitor Prof. Dr. José Fernandes de Lima.

A todos meus professores do Curso de Graduação da Faculdade de Odontologia da Universidade Federal de Sergipe, que certamente, em muito contribuíram para a minha formação profissional e amor a docência.

Ao corpo docente da Faculdade de Odontologia da Universidade Federal de Sergipe, pelo incentivo e confiança em mim depositados, em especial à

Prof. ${ }^{a}$ Edite Maria Bastos Paixão.

\author{
À Pró-Reitoria de Pós-Graduação e Pesquisa \\ da Universidade Federal de Sergipe na pessoa do \\ Prof. Dr. José do Patrocínio, pelo apoio fundamental \\ durante a realização deste curso.
}

À todos os funcionários da Faculdade de Odontologia de Bauru,

da Universidade de São Paulo, que atendem gentilmente às nossas solicitações.

Meu muito obrigado!! 


\section{SUMÁRIO}

Lista de Abreviaturas e Símbolos...........................................................iv

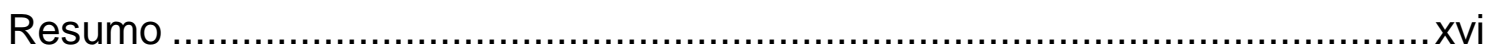

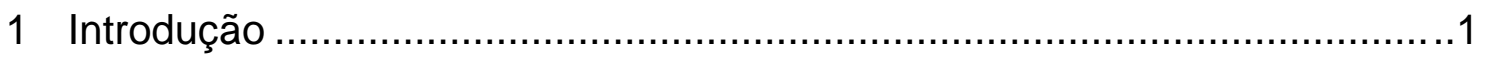

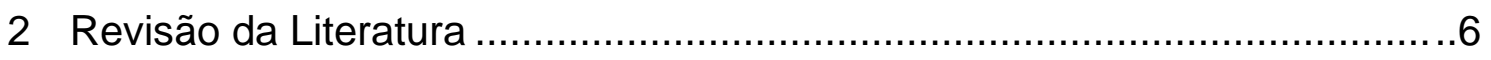

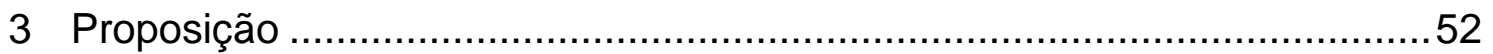

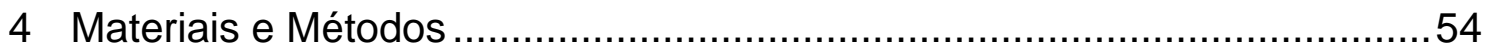

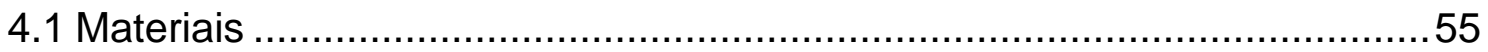

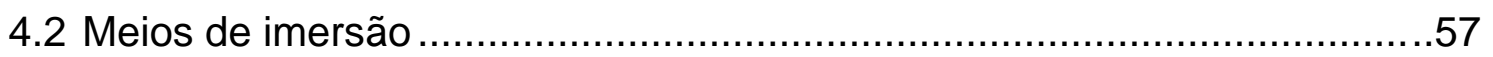

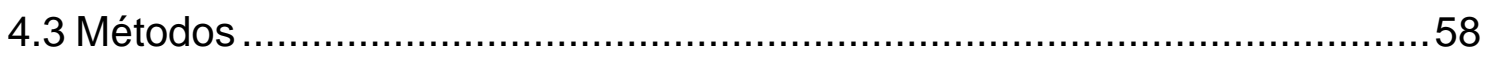

4.3.1 Confecção dos corpos-de-prova ............................................... 58

4.3.2 Preparação dos recipientes para armazenamento e imersão dos corpos-de-prova........................................................................... 61

4.3.3 Determinação da concentração de flúor .........................................63

4.3.3.1 Análise da concentração de flúor pelo método direto .......................63

4.3.3.2 Análise da concentração de flúor após difusão facilitada por HMDS.65

4.3.4 Análise estatística .................................................................6

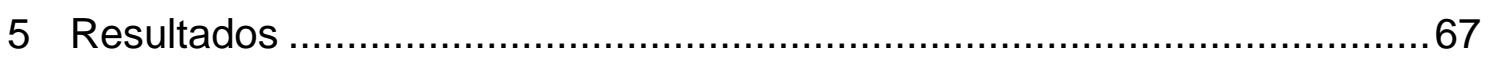

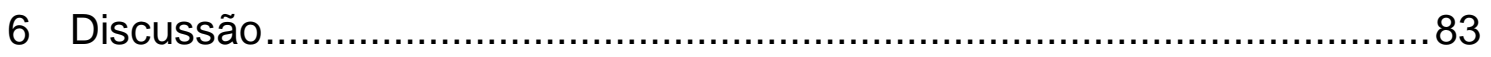

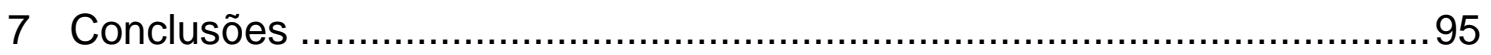

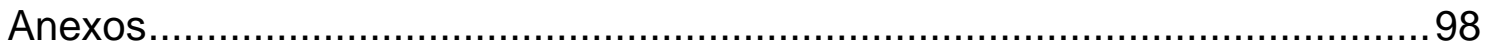

Referências Bibliográficas ............................................................ 112

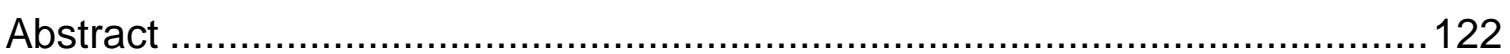




\section{LISTA DE ABREVIATURAS E SÍMBOLOS}

\begin{tabular}{ll}
$\mu$ & porcentagem \\
$\mu \mathrm{g}$ & micrograma \\
$\mu \mathrm{gF}^{-}$ & micrograma Flúor \\
$\mu \mathrm{gF}^{-} / \mathrm{cm}^{2}$ & micrograma Flúor/centrímetro quadrado \\
$\mu \mathrm{gF}^{-} / \mathrm{ml}^{2}$ & micrograma Flúor/mililitro \\
$\mu \mathrm{gF}^{-} / \mathrm{mm}^{2}$ & micrograma Flúor/milímetro quadrado \\
$\mu \mathrm{l}$ & microlitro \\
$\mathrm{Bis-GMA}$ & bisfenol-glicidil-metacrilato \\
$\mathrm{Ca}$ & cálcio \\
$\mathrm{CDTA}$ & ácido 1,2-cicloexanodiaminotetracético \\
$\mathrm{CIV}$ & cimento(s) de ionômero de vidro \\
$\mathrm{h}$ & centrímetro \\
$\mathrm{cm}$ & centrímetro quadrado \\
$\mathrm{Cm}$ & ciclagem de pH \\
$\mathrm{CpH}$ & desmineralização \\
$\mathrm{DES}-$ & horas \\
\hline &
\end{tabular}




\begin{tabular}{|c|c|}
\hline $\mathrm{HA}$ & hidroxiapatita \\
\hline HEMA & 2-hidroxi-etil-metacrilato \\
\hline HMDS & hexameti-disilazano \\
\hline M & Molar \\
\hline $\mathrm{ml}$ & mililitro \\
\hline $\mathrm{mm}$ & milímetro \\
\hline $\mathrm{mM}$ & milimolar \\
\hline $\mathrm{mm}^{2}$ & milimetro quadrado \\
\hline $\mathrm{mV}$ & milivolts \\
\hline $\mathrm{mW} / \mathrm{cm}$ & miliwatts/centrímetro \\
\hline $\mathrm{N}$ & normal \\
\hline$\stackrel{\circ}{\mathrm{C}}$ & grau Celsius \\
\hline $\mathrm{pH}$ & concentração hidrogeniônica \\
\hline ppm & partícula por milhão \\
\hline r.p.m. & rotações por minuto \\
\hline $\mathrm{RE}$ & remineralização \\
\hline TEGDMA & (demitacrilato de trietilenoglicol) \\
\hline TISAB & Total Ionic Strenght Adjustement Buffer \\
\hline UDMA & uretano dimetacrilato \\
\hline $\mathrm{YbF}_{3}$ & tri-itérbio de flúor \\
\hline
\end{tabular}




\section{RESUMO}

O flúor tem um papel importante na estrutura dentária diminuindo a desmineralização e potencializando a remineralização. É fundamental conhecer o comportamento dos materiais restauradores no que diz respeito a liberação de flúor, não só em água deionizada, mas também em condições de desafio ácido. O objetivo desse trabalho foi avaliar a liberação de flúor de 6 materiais restauradores, em dois meios de imersão, água deionizada e sistema de ciclagem de $\mathrm{pH}$ entre, por 15 dias. Os materiais utilizados foram o Vitremer (VIT), o Dyract (DYR), o Ariston (A), o Tetric Ceram (TET), o Definite (DEF) e o Z 100. Para cada material foram confeccionados 16 corpos-de-prova na forma de discos (11 $\mathrm{mm}$ de diâmetro e $1,5 \mathrm{~mm}$ de espessura), os quais foram armazenados individualmente em $4 \mathrm{ml}$ de cada solução, sendo 8 para cada meio de imersão. $\mathrm{Na}$ ciclagem de $\mathrm{pH}, \mathrm{o}$ material era mantido 6 horas na solução desmineralizante e 18 horas na solução remineralizante. As soluções foram trocadas diariamente e os espécimes armazenados durante 15 dias. A liberação de flúor foi medida em $0,5 \mathrm{ml}$ de solução adicionada a igual volume de TISAB II. Para os materiais Z 100, DEF e TET em água deionizada, a liberação de flúor foi obtida pela técnica da difusão facilitada por HMDS, nos períodos de 1, 7 e 15 dias. A análise da concentração de flúor foi medida por eletrodo específico para flúor, acoplado ao aparelho analisador de $\mathrm{pH} / \mathrm{F}^{-}$. Todos os materiais liberaram mais flúor no sistema de ciclagem de $\mathrm{pH}$, exceto 
o Ariston. O pico de liberação foi maior no $1^{\circ}$ dia, declinando do $2^{\circ}$ dia em diante, e alcançando níveis baixos e constantes a partir do $7^{\circ}$ ao $15^{\circ}$ dia. Os resultados foram submetidos a análise de variância a 3 critérios e ao teste de Tukey $(p<0,05)$, para as comparações múltiplas. A liberação total no período do experimento em ordem decrescente, em água deionizada, em $\mu \mathrm{gF}^{-} / \mathrm{mm}^{2}$, foi A (3,6603), VIT (1,7529), DYR (0,2481), TET (0,0140), DEF $(0,0086)$ e Z 100 $(0,0020)$ e em ciclagem de $\mathrm{pH}$, VIT $(3,4366)$, A (2,1422), DYR $(1,0691)$, TET $(0,0297), Z 100(0,0067)$ e DEF $(0,0063)$. Assim concluímos que os materiais apresentaram padrão semelhante de liberação de flúor, exceto o Ariston, que mostrou comportamento estável e liberação constante durante os 15 dias, nos dois meios de imersão. Na ciclagem de $\mathrm{pH}$, houve uma tendência de liberação de flúor de todos os materiais. 
1 INTRODUÇÃO 


\section{INTRODUÇÃO}

Grandes foram, no século passado, os avanços nos estudos sobre a influência do flúor na prevenção da cárie dentária ${ }^{51}$. Após um longo período, em que produtos contendo flúor em altas concentrações eram recomendados como o método mais eficiente, os conceitos referentes à ação anticariogênica mostram na atualidade, que ela é mais eficiente quando o flúor é ministrado em concentrações baixas, mas permanentes no meio bucal, por períodos os mais longos possíveis.

A ocorrência de flúor na cavidade bucal, exercendo influência sobre a adequação do seu meio e, mais particularmente o seu contato na interface dente/restauração, é de grande importância para prevenir a desmineralização inicial e secundária nas margens das cavidades nos dentes. Ela pode aumentar a longevidade dos tratamentos restauradores quando associada a outros fatores, que incluem os cuidados do paciente, a habilidade do profissional e características inerentes ao material restaurador.

Diferentes níveis de flúor contribuem para promover a remineralização do esmalte e da dentina expostos ao desafio ácido ${ }^{39}$ e podem ser conseguidos pela liberação desse íon presente na água de abastecimento, nos produtos para aplicação tópica, nas soluções para bochechos e nos dentifrícios fluoretados, métodos já estabelecidos na prevenção e controle da cárie dentária ${ }^{2}$. 
A incorporação do flúor em materiais dentários portanto, tem despertado interesse especial, por se constituir em uma fonte potencial de liberação desse elemento em baixas concentrações, e por períodos prolongados de tempo ${ }^{14}$.

O cimento de silicato foi amplamente utilizado no passado como material restaurador, tanto por ser o único com características estéticas disponível para as restaurações diretas, como e principalmente pela sua ação anticariogênica, levando a uma baixa incidência de cárie secundária nas margens da restauração, como também nos dentes adjacentes e em contato com a restauração, além de apresentar coeficiente de expansão térmica próximo àquele do dente. Estudos posteriores surgiram na tentativa de desenvolver materiais dentários com propriedades físicas, mecânicas e biológicas adequadas, incluindo a liberação de flúor e a adesividade à estrutura dental, compatíveis com o meio bucal.

Na década de 70, Wilson e Kent desenvolveram, a partir do pó do cimento de silicato e do líquido do cimento de policarboxilato de zinco, um material que, tudo indicava ter essas propriedades - o cimento de ionômero de vidro. O cimento descoberto tinha comprovadamente a capacidade de liberar flúor e oferecer maior proteção às estruturas dentárias impedindo muitas vezes que a fase de desmineralização que dá início ao processo de cárie, prevalecesse. Esses materiais, no entanto, apesar da comprovada adesividade aos tecidos duros do dente, não atendem devidamente às necessidades estéticas e mecânicas, fundamentais para o bom desempenho clínico nas restaurações.

A ação preventiva da liberação de flúor a partir de materiais restauradores como o cimento de silicato e o de ionômero de vidro convencional, 
tem encorajado fabricantes de materiais dentários a promover aperfeiçoamentos nesses materiais assim como a incorporação de flúor, por exemplo, nas resinas compostas $^{1}$. As resinas modificadas por poliácidos, Compômeros, idealizados com este objetivo não preenchem totalmente estas expectativas, pois, apesar de serem materiais com estética favorável suas propriedades de liberação de flúor são inferiores àquelas dos cimentos ionomêricos e sua resistência mecânica é inferior à das resinas compostas. ${ }^{6}$

Atualmente as pesquisas visam a desenvolver materiais com características que atendam às expectativas tanto do cirurgião-dentista como dos pacientes, tais como: resistência mecânica capaz de suportar os esforços mastigatórios e boa adaptação marginal, possibilitando maior longevidade dos tratamentos, além de excelente qualidade estética. Rapidez de aplicação e custos viáveis à realidade econômica mundial. Materiais restauradores que dispensam a utilização de recursos laboratoriais e equipamentos especiais, devido à facilidade da técnica para sua utilização estão sendo aperfeiçoados em todos os seus pontos, visando à obtenção de restaurações para dentes posteriores, livres de mercúrio, resistentes, duradouras e estéticas.

Não se pode porém, deixar de admitir, que complementando a ação preventiva do flúor, ainda o tratamento mais eficaz para a doença cárie é a adequação de hábitos alimentares e de higiene, associados ao efetivo controle de placa, capazes de equilibrar o meio bucal, ou melhor, atuar na promoção de saúde bucal. Para tal vêm sendo desenvolvidos materiais "inteligentes" com a proposta de reduzir as cáries secundárias e neutralizar as quedas cíclicas intra-bucais de $\mathrm{pH}$, 
especialmente em pacientes do grupo de alto risco, com propriedades mecânicas e estéticas semelhantes às das resinas compostas de partículas pequenas de carga utilizadas nas restaurações de lesões em dentes posteriores.

Desta forma, parece válido analisar a liberação quantitativa de flúor, comparando cimentos ionomêricos modificados por resina, resinas modificadas por poliácidos e resinas compostas, utilizando-se dois meios de armazenamento, quais sejam a água deionizada e um sistema de ciclagem de $\mathrm{pH}$, que utiliza uma solução desmineralizante alternada com uma solução remineralizante (saliva artificial), simulando o ambiente e as circunstâncias dinâmicas em que se dá o processo de cárie. 
2 REVISÃO DA LITERATURA 


\section{REVISÃO DA LITERATURA}

Em 1963, JENKINS ${ }^{41}$ descreveu a forma de ação do flúor na redução da cárie dentária. Três são as propriedades do íon flúor na concentração fisiológica que provavelmente estão relacionadas com a sua ação no corpo humano: troca iônica com a hidroxila da apatita, para formar menor quantidade de apatita solúvel; tendência em favorecer a precipitação do fosfato de cálcio a partir de soluções saturadas; inibição de algumas enzimas e a aparente estimulação de outras. A partir de experimentos com esmalte e dentina triturados, com concentrações de flúor entre 75 - 100 ppm, a ação mais importante é uma troca iônica com a hidroxila da hidroxiapatita para formar fluorapatita. Em maiores concentrações, ocorrem muitas outras reações como a troca de carbonatos, a precipitação de fluoreto de cálcio e fluoreto de magnésio na superfície cristalina, e possivelmente adsorção. A relação recíproca entre o flúor e o carbonato do osso fluoretado tem sido citada e resultados semelhantes vêm sendo encontrados em dentes incisivos de ratos e em dentes humanos. Esses achados demonstraram como o flúor penetra nos tecidos calcificados, em parte às expensas do carbonato, como também pela troca com o íon hidroxila. A redução na solubilidade do esmalte e da dentina é um fator importante na ação anticariogênica promovida pelo flúor, observado no tratamento de osso, dente, ou fosfato de cálcio com soluções fluoretadas, com variação da concentração inicial 
não menor de 1 ppm, pode reduzir prontamente a solubilidade. O autor explicou o efeito do flúor na precipitação de fósforo a partir da saliva, num experimento com 8 hamsters. Durante 24 dias foi administrado $0,04 \mathrm{mg}$ de flúor, seguido de injeção de fósforo para deles. Foi observado mais fósforo depositado nos dentes destes animais que nos do grupo controle que só receberam flúor, concluindo que, o flúor favorece a deposição do mineral, a partir de soluções saturadas, como a saliva.

Em 1986, FEATHERSTONE et al. ${ }^{26}$ utilizaram um método para estudar o efeito da baixa concentração de flúor no aumento da remineralização. Esse modelo in vitro de ciclagens de desmineralização e remineralização foi desenvolvido a partir da reprodução dos resultados de experimentos in vivo. Pacientes com indicação de extrações de pré-molares, por razões ortodônticas foram selecionados e divididos em 4 grupos experimentais. Todos eles tiveram brackets ortodônticos colados na superfície bucal dos dentes teste e orientados a desenvolverem um tratamento preventivo durante 30 dias. $O$ grupo I realizou apenas escovação com dentifrício fluoretado, o grupo II, escovação com dentifrício fluoretado mais bochechos diários de fluoreto de sódio a 0,05\%, e o grupo III, escovação com dentifrício fluoretado mais aplicações tópicas semanais de gel de flúor fosfato acidulado a $1,23 \%$ e o grupo IV, somava as três formas anteriores, escovação, bochecho e aplicação tópica. Após esse período, os dentes com brackets foram extraídos e avaliados quanto ao grau de desmineralização pelo teste de microdureza, observando que ocorreu perda mineral em torno de 5 a 15\% de volume para os grupos que receberam dentifrício fluoretado. Para os grupos que usaram dentifrício mais bochecho e dentifrício 
mais aplicação tópica houve uma completa inibição da desmineralização ou completa remineralização. Esses resultados foram reproduzidos em um modelo de ciclagens de desmineralização e remineralização in vitro, incluindo tratamentos diários com produtos contendo flúor. O efeito da baixa concentração no processo de remineralização foi obtida pela adição de flúor com concentração de 0,03 a 0,5 $\mathrm{mg} / \mathrm{l}$, resultando em significante aumento da remineralização, variando de acordo com a concentração. Esses estudos confirmam a importância da presença do flúor continuamente em concentrações relativamente baixas, favorecendo a diminuição de cáries, mesmo em condições de altos desafios cariogênicos.

\section{Em 1988, o CONSELHO DE MATERIAIS DENTÁRIOS,} INSTRUMENTOS E EQUIPAMENTOS DA A.D.A. ${ }^{2}$ publicou relatório sobre os materiais dentários que contêm flúor, citando o aparecimento de cáries secundárias como a causa mais comum de falhas de quase todas as restaurações, decorrente do fenômeno da microinfiltração ao longo da interface dente/restauração. Portanto, até que um sistema adesivo eficiente esteja disponível, existe interesse em minimizar o surgimento de cáries nessa interface, aumentando o efeito anticariogênico a partir do próprio material. Para atingir esse objetivo, o mais óbvio é a incorporação de flúor na estrutura do material, dada sua ação na redução da cárie pelos métodos de ações preventivas já estabelecidos. O cimento de silicato é um tradicional material restaurador contendo fluoretos como fundentes na sua composição, na concentração em cerca de 12 a 15\% no pó enquanto, o cimento de ionômero de vidro apresenta uma concentração de flúor de aproximadamente 22\%, incorporado ao pó. O mecanismo básico de ação do flúor é a reação com a estrutura dentária adjacente reduzindo sua solubilidade 
em ácidos, pelo processo de dissolução ou lixiviação do fluoreto a partir do cimento. O esmalte exposto ao cimento de ionômero de vidro apresentou aumento na concentração de flúor e maior redução da solubilidade aos ácidos, comparado ao cimento de silicato. O flúor disponível pode ser monitorado avaliando-se sua absorção pelo esmalte adjacente à interface dente/material e a redução da solubilidade do esmalte em ácido. Os níveis de liberação de flúor conhecidos a partir dos cimentos de silicato ou de ionômero de vidro são referências para outros materiais.

SWIFT ${ }^{59}$, em 1989, avaliou o padrão e a quantidade de liberação de flúor, comparando 2 marcas comerciais de resinas compostas (FluorEver e Heliomolar Radiopaque) com o cimento de ionômero de vidro tipo II (Ketac Fill). Para tal, moldes de Teflon com cavidades em forma de disco, foram utilizados na confecção dos corpos de prova com 10 mm de diâmetro e 2,5 mm de espessura,. Os espécimes foram individualmente imersos em $4 \mathrm{ml}$ de água deionizada, que era trocada diariamente, durante 2 semanas. Uma solução tampão TISAB II foi adicionada, sendo a quantidade de flúor liberada medida com um eletrodo específico, íon flúor sensível (Orion). O padrão de liberação de flúor foi semelhante para os 3 materiais, mas a concentração liberada foi maior durante as primeiras 24 horas, declinando rapidamente no segundo dia, e diminuindo gradualmente até atingir um nível quase constante. A concentração de flúor, nas avaliações após 24 horas, foi maior no cimento de ionômero de vidro Ketac Fill que na resina composta FluorEver, embora a quantidade de flúor liberada tenha sido a mesma, nas primeiras 24 horas. Para a resina composta Heliomolar Radiopaque a quantidade de flúor liberada foi muito pequena sendo portanto, 
mínima ou quase nenhuma a inibição de cáries secundárias. Entretanto, o autor afirma que, a presença de uma pequena quantidade de flúor pode produzir algum efeito cariostático se mantido em concentração baixa e constante no meio bucal.

FORSTEN $^{30}$ em 1990, também concluiu este fato, ao avaliar a liberação de flúor a curto e a longo prazo, em 10 diferentes materiais no período de 2 anos. Utilizou 4 cimentos ionômericos restauradores convencionais (ASPA, Fuji II, ChemFil II, Ketac-Fil), um cimento ionomêrico para selamento de fissuras (Fuji III), três cimentos ionomêricos com partículas de metal (Ketac-Silver, Miracle Mix, Fuji II + Sybralloy), um amálgama (Fluor Alloy) e uma resina composta (Heliomolar Radiopaque) contendo flúor. Amostras cilíndricas medindo 10,7 mm de diâmetro e 2,8 mm de espessura foram confeccionadas em moldes plásticos. Após os corpos de prova terem sido estocados por um período de 24 horas, foram continuamente expostos a água corrente não fluoretada $(\mathrm{F}<0,1 \mathrm{ppm}, \mathrm{pH} 8,0)$ num volume de 0,5 I / min, exceto quando era medida a liberação de flúor. Para tanto cada espécime era transferido para $5 \mathrm{ml}$ de água destilada e deionizada após 24 horas de armazenamento nos primeiros 2 meses e, por uma semana nos meses subseqüentes. A quantidade de flúor presente na água era medida por meio de um analisador do íon (EA 940, ORION), usando um eletrodo de flúor (94-09) e um eletrodo de referência $(900100,4 \mathrm{M} \mathrm{KCl}+\mathrm{AgCl})$. O autor verificou que nos cimentos restauradores ionômeros de vidro, o flúor é liberado por pelo menos 2 anos, diminuindo com o passar do tempo, mas mantendo-se superior a 0,5 ppm após um ano. No segundo ano, a maioria dos cimentos ionomêricos continuam liberando flúor de forma constante e em menor nível, suficiente para produzir um efeito anticariogênico. No amálgama e na resina a liberação foi menor. Observou 
ainda, que a liberação de flúor aumentava quando o pH diminuía na solução estoque, melhorando portanto as propriedades de prevenção à cárie e proteção do dente à desmineralização pelos cimentos ionômeros de vidro restauradores.

Em 1990, TEN CATE ${ }^{62}$ fez um levantamento de estudos in vitro sobre o efeito do flúor no processo de des- e remineralização. A atual literatura descreve a importância de um meio fluoretado nesse processo. A presença de flúor constante e em baixa concentração promove, efetivamente, a deposição mineral e a inibição da dissolução de minerais. O fenômeno posterior está muito provavelmente associado à precipitação concomitante de uma fase mineral rica em flúor, a qual inibe futuras dissoluções, resultando na inibição da desmineralização do esmalte e um aumento da remineralização de suas lesões, podendo também, pela ação do flúor, induzir a paralisação da lesão de esmalte. Segundo o autor, nos processo de des e remineralização, os padrões e efeitos de substâncias que previnem cáries podem ser examinados por meio da metodologia de ciclagem de $\mathrm{pH}$, por ser este um modelo laboratorial que melhor simula as variações de $\mathrm{pH}$ que ocorrem no meio bucal.

DESCHEPPER et al. ${ }^{17}$, em 1991, compararam as quantidades e os padrões de flúor de 11 cimentos de ionômero de vidro. 10 corpos de prova de cada material foram imersos individualmente em $1 \mathrm{ml}$ de saliva artificial (VAOralube) a $37^{\circ}$ e transferidos para nova solução nos períodos de $1,4,7,14,24$, 56 e 84 dias, após serem lavados com $1 \mathrm{ml}$ de água deionizada sobre o tubo original. A concentração de flúor de cada período de incubação em saliva artificial foi determinada adicionando $2 \mathrm{ml}$ de TISAB com CDTA à solução teste, utilizando- 
se de um eletrodo flúor específico e um analisador digital de íon (medidor de $\mathrm{pH} / \mathrm{mV}$, ORION ). Os valores obtidos, transformados em $\mu \mathrm{g} \mathrm{F} / \mathrm{mm}^{2}$, foram submetidos aos testes estatísticos de análise de variância de uma variável para cada intervalo de tempo e o teste de Tukey para múltiplas comparações para determinar as diferenças estatisticamente significantes entre os materiais. Os autores concluíram que o padrão de liberação de flúor foi semelhante para todos os cimentos de ionômero de vidro, sendo que os maiores valores foram observados nas primeiras 24 horas após a mistura. Entretanto, a quantidade de flúor liberada foi estatisticamente diferente entre os diversos materiais, em decorrência dos vários fatores controladores da liberação de flúor, tais como a composição, solubilidade e porosidade do material, e a natureza do meio de imersão.

REZK-LEGA; ÖGAARD; RÖLLA ${ }^{54}$ em 1991, avaliaram a disponibilidade de flúor dos CIV fotoativados, em saliva humana, como solução de armazenamento. Os autores utilizaram dois CIV para cimentação: Ketac Cem e Aqua Cem, mantidos por 1 hora em água destilada com $\mathrm{pH} 7,0$, em saliva com $\mathrm{pH}$ 7,0, em água pré-tratada com saliva com $\mathrm{pH}$ 4,5 e em soluções tampão de albumina e fosfato com $\mathrm{pH} 7,0$, quando então era medido o flúor liberado. Observaram que a concentração do flúor disponível foi reduzida pela presença de proteína e fosfato e aumentada quando o $\mathrm{pH}$ foi reduzido de 7,0 para 4,5, sugerindo que a liberação de flúor in vivo seja controlada pelo $\mathrm{pH}$.

Os mecanismos de liberação de flúor foram observados por GRIFFIN et al. ${ }^{35}$ em 1992 , ao avaliar o efeito de "liners" contendo flúor na inibição de 
cáries. Nesse estudo, o efeito imediato explosivo da liberação de flúor foi significantemente maior que nos outros materiais restauradores. Essa explosão inicial ocorre após a reação de endurecimento inicial do material e sua exposição ao ambiente bucal, ocorrendo dissolução superficial, devido ao ataque ácido do meio. A liberação de íons e sua subsequente disponibilidade ocorre por 3 mecanismos distintos: dissolução superficial, difusão através de micro canais e poros e, difusão de massa.. A grande disponibilidade de flúor dos CIV pode ser devida a esses mecanismos.

Em 1994, CAO et al. ${ }^{11}$ realizaram ao longo de 4 meses, um estudo contínuo sobre a liberação de flúor de vários tipos de CIV e resinas compostas (Ketac-Fil, Photac-Fil, Fuji II Cap, Fuji II LC, Vitremer, FluoroCore, Geristore, VariGlass, FluroSheild, Pertac-Hybrid, Mirage FLC, Heliomolar RO, Resiment). Cada amostra foi colocada em $10 \mathrm{ml}$ de água deionizada que era trocada e analisada semanalmente por meio do eletrodo Orion 96-09, e uma solução tampão TISAB II. Os resultados em $\mu \mathrm{g} F / \mathrm{cm}^{2}$, mostraram que todos os materiais apresentaram uma alta liberação inicial de flúor, que decresce exponencialmente entre a primeira e segunda semanas, continuando em declínio lento durante as semanas seguintes. Os autores concluíram que a taxa de liberação de flúor variou na dependência do tipo de material e das formulações das marcas comerciais, sendo que os CIV convencionais liberaram mais flúor do que os CIV resinosos, e as resinas compostas apresentaram as menores quantidades de flúor liberado, durante os 4 meses de estudo. 
CREANOR et al. ${ }^{15}$, em 1994, estudaram as características de liberação e aquisição de flúor dos CIV. Foram preparadas 10 amostras em forma de disco (6 mm de diâmetro e 1,5 mm de altura) dos materiais Ketac-Fil, Chemfil Superior, Fuji II LC, Aquacem e Vitrebond e submersas individualmente em $2 \mathrm{ml}$ de água deionizada por um período de 60 dias, sendo trocada a cada 6 horas no $1^{\circ}$ dia e diariamente até $01^{\circ}$ dia e, em seguida, a cada 3 e 4 dias até o final do experimento. A quantidade de flúor liberada foi medida em cada solução com eletrodo específico. A aquisição de flúor pelo CIV foi verificada após 60 dias em água deionizada, quando as 10 amostras foram divididas em 2 grupos: controle e teste. As amostras do grupo teste eram expostas a solução de 1000 ppm F por 2 minutos, diariamente, e as do grupo controle eram mantidas em água deionizada, por um período de 20 dias. Todos os materiais testados liberaram quantidades mensuráveis de flúor durante o período avaliado, com a mais alta taxa no 1ํ dia, diminuindo rapidamente no $2^{\circ}$ dia e atingindo um nível quase constante a partir do 10ํ dia; continuando a liberar níveis menores até 0 60ํํ. dia. No teste de captação/liberação de flúor, as amostras expostas a solução fluoretada liberaram mais flúor iônico que o grupo controle, indicando que o flúor pode ser absorvido e, posteriormente, liberado no CIV.

Em 1994, DONLY ${ }^{21}$ fez um levantamento sobre a importância da inibição da desmineralização das margens de cavidades em esmalte e dentina em restaurações com materiais que liberam flúor. Uma abordagem dos principais materiais utilizados com essa finalidade foi realizada: cimentos de ionômero de vidro, resinas compostas que liberam flúor e amálgama. A maioria foi centrada em estudos in vitro, com respostas favoráveis à inibição de desmineralização. 
Independentemente ser cimento de ionômero de vidro de presa química ou ativada por luz, convencional ou modificado por resina. A própria reação de endurecimento do material age no sentido de liberar o flúor, através da interação das partículas vítreas com o ácido poliacrílico. As resinas compostas não apresentam uma ação direta com o substrato, dado à interferência de primers e adesivos sem flúor, minimizando essa ação anticariogênica. Fatores como presença de smear layer podem diminuir essa inibição desejada. O amálgama é menos aplicado com esta finalidade. O comportamento desses materiais sugere a utilização deles no aumento da resistência à recorrência de cárie, agindo como fontes de flúor.

Em 1995, COSTA et al. ${ }^{14}$ realizaram um estudo comparativo das quantidades e padrões de liberação de flúor de materiais dentários restauradores em água deionizada por um período de 14 dias. Espécimes em número de 6, em forma de disco medindo $11 \mathrm{~mm}$ de diâmetro e $1,5 \mathrm{~mm}$ de espessura foram preparados utilizando-se matrizes de aço inoxidável. Os materiais foram manipulados de acordo com os fabricantes em temperatura ambiente de $\pm 24^{\circ} \mathrm{C}$ e umidade relativa controlada de $\pm 50 \%$. Os teste foram feitos por suspensão dos espécimens em tubos de polietilieno contendo $32 \mathrm{ml}$ de água destilada e deionizada, armazenados em estufa a $37^{\circ}$ C. A água era trocada a cada 24 horas. A quantidade de flúor presente nas soluções foi medida adicionando-se 3,2 ml de TISAB III e utilizando-se um eletrodo específico para o íon flúor (ORION 96-09 e 94-09), acoplado ao analisador de íons digital (PROCYON, modelo SA720). Os valores obtidos em ppm, foram transformados em $\mu \mathrm{gF}^{-}$e divididos pela área do espécime, sendo expressos em $\mu \mathrm{gF}^{-} / \mathrm{mm}^{2}$. Os resultados mostraram 
que os materiais Chelon-Fil, Vitremer, Chelon Silver e Variglass diferiram quanto à quantidade de flúor liberado, sendo que o Chelon-Fil liberou as maiores quantidades, seguido do Vitremer. Todos os materiais apresentaram o mesmo padrão de liberação, maior nas primeiras 24 horas, declinando a taxas menores e tendendo a estabilizar-se com o passar do tempo. Quando os resultados foram comparados ao total de flúor liberado pelo teste de análise de variância e o teste de Tukey evidenciaram-se diferenças estatisticamente significantes entre 0 Chelon Silver e o Variglass nas 24 horas e, entre o Chelon Silver e o Vitremer no $3^{\circ}$ dia.

Em 1995, ERICKSON e GLASSPOOLE ${ }^{24}$ descrevendo sobre um modelo de investigação da inibição de cáries por meio de materiais restauradores com capacidade de liberar flúor, refere-se e esses materiais numa seqüência evolutiva, cimento de silicato, cimento de ionômero de vidro convencional e híbrido. Entre os materiais mais estudados, destaca-se o CIV convencional pela capacidade adesiva ao esmalte e a dentina e por uma reação ácido-base de endurecimento, resultando em liberação de vários íons, inclusive o flúor, característico desse grupo de materiais. Apresenta inicialmente um pH ácido, em torno de 2,0, que tende a neutralizar durante a vida útil do material. Os CIV híbridos, além da reação ácido-base, são ativados pela luz, semelhantes às resinas compostas, mas são menos ácidos, $\mathrm{pH}$ em torno 4,0. Os sistemas resinosos podem conter flúor sob diversas formas, sais orgânicos, vidros ou flúor orgânico. São sistemas não aquosos que se ativam através de radicais livres de monômeros funcionais de metacrilato. O processo de liberação de flúor em água ocorre de duas formas: uma liberação superficial e rápida e, difusão lenta pela 
massa. A maioria das pesquisas são realizadas em água, sendo usada a saliva artificial, como também a saliva humana, em alguns experimentos. Os resultados da liberação de flúor em saliva artificial são significantemente menores que em água, provavelmente pela deposição de componentes salivares sobre a superfície do material restaurador, reduzindo o nível de liberação. A capacidade dos CIV de absorver fluór proveniente dos produtos de uso tópico, eleva o seu nível de liberação por várias semanas. A possibilidade de readquirir flúor superficialmente, nos CIV ocorre pela reação ácido aquosa com o esmalte e a dentina, e pode ocorrer por difusão pelos tecidos dentais, na ausência de meio ácido. Os autores concluíram que existem várias formas de estudar a inibição da cárie in vitro pela liberação de flúor dos materiais restauradores e o seu comportamento no processo de desmineralização do esmalte e dentina. Entretanto, por não reproduzirem as reais condições da cavidade bucal, não é possível estabelecer a sua total correlação clínica.

FORSTEN ${ }^{28}$, em 1995, estudou o padrão de liberação de flúor e a capacidade de recarga dos ionômeros modificados por resina (Fuji II LC, Fuji II LC, Photac Fil, Variglass), do compômero (Dyract), e do ionômero convencional (Fuji II). A influência da proporção pó-líquido e do meio ácido na quantidade de flúor liberada também foram avaliadas. Após 1 mês, todos os materiais, exceto o Fuji II LC, apresentaram uma liberação de flúor significantemante menor comparada àquela observada após 24 horas. Todos os materiais avaliados, exceto o Dyract e o Variglass, após 9 meses de armazenamento em água, liberaram significantemente quantidades menores de flúor comparadas as que foram medidas após tratamento de recarga com 50 ppm de flúor, durante 1 
semana. A liberação de flúor em $\mathrm{pH} 5,0$ foi maior do que em $\mathrm{pH} 6,0$, para todos os materiais, após 11 meses de estocagem em água corrente.

ISMAIL $^{39}$, em 1995, estudou a quantidade de flúor efetiva para prevenir a desmineralização e demonstrou, através de uma revisão de trabalhos realizados in vitro, que a concentração de flúor tão baixa como a de 0,01-0,03 ppm na solução, pode possibilitar uma discreta remineralização. A adição de 0,03 ppm de flúor na solução desmineralizante durante o processo Des-Re foi capaz de reduzir em $50 \%$ a profundidade da lesão cariosa e que a exposição ao flúor de forma constante e contínua, no meio bucal, na concentração de 0,2 ppm, promove uma redução da desmineralização em $50 \%$. Outros estudos in vitro evidenciam que a concentração efetiva mínima está relacionada com a concentração de íons de hidrogênio na solução desmineralizante, indicando que a concentração do fluoreto varia com a atividade de cárie e o nível de queda do pH, após exposição a carboidratos fermentáveis. Portanto, para que ocorra remineralização, a concentração mínima efetiva de flúor está inversamente relacionada ao $\mathrm{pH}$ salivar, quanto maior o pH menor a quantidade mínima de flúor necessária. Estudos epidemiológicos evidenciam claramente que a exposição ao flúor em baixas concentrações, diárias e freqüentes é mais efetiva que a exposição não contínua de produtos com altas concentrações, como as dos produtos de aplicações tópicas.

ARAÚJO et al. $^{3}$ avaliaram in vitro, em 1996, a quantidade de flúor liberada por materiais restauradores contendo flúor ao longo de 28 dias. Foram preparados 6 corpos de prova de cada material com diâmetros de 2,06 $\pm 0,06 \mathrm{~cm}^{2}$ 
e divididos em 7 grupos: grupo 1 - Chelon Fil, grupo 2 - Chelon Silver, grupo 3 Variglass, grupo 4 - Dyract, grupo 5 - Vitremer, grupo 6 - Vitremer + Scothbond Multipurpose, grupo 7 - Fuji II LC. As amostras foram armazenadas por 24 horas com umidade relativa em $100 \%$ e então mantidas suspensas em tubos plásticos individualizados, contendo $5 \mathrm{ml}$ de água deionizada e submetidas a constante agitação à temperatura ambiente de $25^{\circ} \mathrm{C}$, sendo a água trocada a cada 24 horas. A liberação de flúor foi determinada com 1, 2, 3, 4, 5, 7, 14 e 28 dias após tamponar a solução com igual volume de TISAB pH 5,0. A liberação de flúor foi medida com um eletrodo específico para íon flúor (Orion 96-09) acoplado a um analisador iônico digital (Orion EA 940) previamente calibrado com soluções padrão contendo 0,05 a $5,00 \mathrm{\mu gF}^{-} / \mathrm{ml}$, e expressa por ppm em solução e, $\mu \mathrm{gF}^{-} / \mathrm{cm}^{2}$. Todos os materiais apresentaram uma liberação de flúor significantemente maior nos 2 primeiros dias que no restante dos intervalos de tempo. Apesar de significante, a variação de liberação de flúor nos tempos seguintes entre os materiais, foi declinando do $1^{\circ}$ ao $28^{\circ}$ dias para todos os grupos de materiais avaliados. A quantidade de flúor liberado neste estudo foi determinada em meio neutro, entretanto, a liberação de flúor é aumentada pela redução do pH do meio de armazenamento. No meio bucal isto pode ser causado, especialmente, pelo desafio acidogênico induzido da placa.

SULJAK; HATIBOVIC-KOFMAN ${ }^{58}$ estudaram in vitro, em 1996, a liberação de flúor inicial e após refluoretação com soluções de 1,000 ppm. Os materiais usados foram os ionômeros modificados por resina (Photac Fil, Fuji II LC, Vitremer) e um compômero (Dyract). A maior liberação na fase inicial ocorreu nas primeiras 24 e 48 horas (Photac Fil > Vitremer > Fuji II LC > Dyract) e 
diminuiu com o tempo. Após 24 horas da refluoretação, todos os materiais apresentaram uma liberação significantemente maior em comparação com o dia anterior à recarga. Todos os materiais liberaram quantidades diferentes de flúor nos 08 primeiros dias, (Photac fil, 15 ppm; Vitremer, 1,0 ppm; Fuji II LC, 0,8 ppm; Dyract 0,2 ppm). O Photac Fil e o Dyract apresentaram respectivamente, a mais alta e mais baixa liberação de flúor. Após a recarga, o Vitremer e o Photac-Fil liberaram maiores quantidades de flúor que o Fuji II LC e o Dyract, nas 03 fases de absorção-recarga, sendo que o Dyract apresentou um nível relativamente constante de liberação durante essas fases, embora a sua reação química de liberação de flúor seja bem diferente quando comparada ao ionômero de vidro. No cimento ionômero modificado por resina, a reação ácido-base se inicia com a sorpção de água, que possibilita as ligações iônicas e a liberação de flúor. Os autores concluíram que em relação à liberação de flúor o Dyract age mais como uma resina composta do que como um ionômero de vidro.

Em 1997, BALLA et al. ${ }^{6}$ estudaram durante 90 dias, a liberação de flúor de diferentes materiais restauradores ativados por luz em comparação com o cimento de ionômero de vidro convencional. O cimento convencional (Ionofil) e os ionômeros de vidro modificados por resina (Vivaglass Liner, Fuji II LC) liberaram maior quantidade de flúor comparados aos compômeros (Dyract, Compoglass) e às resinas (Heliomolar $\mathrm{RO}$, microfina; Tetric, híbrida). A liberação de flúor declinou rapidamente do $4^{\circ}$. ao $90^{\circ}$. dia de maneira variada para os diferentes materiais. Os compômeros apresentaram liberação de flúor significantemente maior que as resinas microfinas e híbridas. O padrão de liberação de flúor do Dyract foi semelhante ao do Compoglass, enquanto o das resinas compostas 
microfinas foi semelhante ao das resinas híbridas. Os autores explicam ainda, que nos cimentos ionômeros de vidro ativados pela luz, a reação ácido-base é seguida pela polimerização dos grupos metacrilatos pela ação da luz visível. No sistema dos compômeros, a fase de polimerização ativada por luz é seguida pela absorção de água, formando mais tarde ligações químicas no material, por meio de reações ácido-base, liberando o flúor. A liberação pela resina composta ocorre lentamente através do processo de difusão. Essa liberação não deve resultar na deterioração de outras propriedades dos materiais.

Com a finalidade de se investigar a liberação de flúor de alguns materiais restauradores estéticos, DONLY; NELSON ${ }^{20}$, em 1997, avaliaram três diferentes categorias de materiais, expostos a um dentifrício fluoretado: resina composta sem flúor (P-50), resina composta com flúor (Heliomolar Radiopaque) e cimento de ionômero de vidro convencional (Ketac Fil). Prepararam dez amostras de cada material e as mesmas foram acondicionados individualmente em $10 \mathrm{ml}$ de água deionizada. Duas vezes por dia, metade das amostras eram escovadas com dentifrício Crest por 2 minutos, lavadas e retornadas nos frascos de origem. As leituras foram realizadas nos períodos de 1,7,14, 21 e 28 dias através de eletrodo específico. Após a análise estatística (ANOVA e Duncan, com $p<0,05$ ), em todos os períodos, os resultados demonstraram a superioridade do cimento de ionômero de vidro comparado aos dois outros materiais testados, sem diferenças estatísticas entre esses dois, em ambas condições a que foram submetidos, isto é, escovados ou não com dentifrício. Desta forma, o cimento de ionômero de vidro foi o único material restaurador testado que apresentou real capacidade de 
reservatório de flúor, apesar do aumento de liberação verificada pelos demais materiais.

FRIEDL et al. ${ }^{32}$, em 1997, estudaram a possível relação entre a liberação de flúor e a inibição de crescimento de colônias de $S$. mutans, microorganismo relacionado à atividade de cárie. Este experimento incluiu um cimento de ionômero convencional (Ketac-Fil), um do tipo cermet (Ketac-Silver), três cimentos de ionômero de vidro modificados por resina (Photac-Fil, Fuji II LC e Vitremer) e um compômero (Dyract), utilizando um sistema líquido de cultura para a análise das curvas de crescimento bacteriano, através de um programa computadorizado. Houve um decréscimo significante na liberação de flúor com o tempo para todos os materiais. A inibição de crescimento bacteriano reduziu com o tempo. Ketac-Silver e Dyract liberaram uma quantidade significantemente menor de flúor que os demais materiais, bem como uma menor inibição no crescimento de colônias. Esta menor liberação de flúor está provavelmente relacionada ao fato de não haver uma reação imediata de um cimento de ionômero de vidro, apenas com a liberação de vidro de fluor-silicato de estrôncio e alumínio. Verificou-se correlação entre as duas características investigadas em todos os períodos de avaliação.

Em 1997, KAN; MESSER; MESSER ${ }^{42}$ compararam a liberação de flúor e a citotoxidade do cimento de ionômero vidro convencional (Ketac-Fil), dos cimentos de ionômero de vidro modificados por resina (Vitremer, Fuji II LC) e da resina composta (Silux Plus). A liberação de flúor variou de 0,1 a 53,4 ppm nos períodos de 1, 4 e 07 dias. Os CIV modificados por resina liberaram quantidades 
de flúor progressivamente maiores em relação ao tempo, enquanto a resina composta liberou quantidades mínimas. O Vitremer foi considerado significantemente citotóxico enquanto, o cimento de ionômero de vidro convencional apresentou citoxicidade intermediária sendo que o Fuji II LC e a resina composta não foram considerados citotóxicos.

O estudo conduzido por MODESTO et al. ${ }^{50}$, em 1997, teve como objetivo avaliar a capacidade de liberação de flúor de restaurações proximais com compômero Variglass, assim como a captação do mesmo pelo esmalte adjacente, comparando este material com um grupo controle de dentes sem restaurações e um grupo restaurado com resina composta (Prisma APH). Sessenta terceiros molares extraídos livres de cárie e trincas evidentes foram selecionados e distribuídos em 3 grupos. Os preparos cavitários foram padronizados e as restaurações procedidas conforme as instruções dos fabricantes, com o auxílio de tira de matriz. Após o acondicionamento a 37ํㅡ e 100\% de umidade relativa até serem removidos os excessos, os dentes restaurados foram selados com esmalte de unha, exceto nas áreas restauradas. Dois dentes do grupo controle foram totalmente selados, sendo que o restante também manteve uma área não selada, correspondente à dimensão das áreas dos dentes restaurados. Os dentes foram montados em bases de resina acrílica em doze séries de cinco dentes de forma que as áreas testadas (restauradas ou não) deveriam estar em contato com as áreas de captação. Por um intervalo de 14 dias consecutivos, os dentes foram submetidos ao desafio cariogênico. O íon liberado nestas soluções foi quantificado através de um eletrodo calibrado com padrões de 0,1 e 1,0 $\mu \mathrm{g} \mathrm{F}^{-} / \mathrm{ml}$, utilizando-se $0,5 \mathrm{ml}$ de TISAB para a mesma medida de solução tampão de 
acetato (1M de $\mathrm{pH} 5,0$, contendo $\mathrm{NaCl} 1 \mathrm{M}$ e CDTA a 0,4\%). Na avaliação de flúor captado pelo esmalte adjacente, um disco de esmalte foi removido e seccionado em 5 camadas variando em profundidade. A massa do esmalte removida, durante cada ataque ácido, foi determinada por meio da mensuração do fósforo inorgânico pelo método colorimétrico, usando um espectofotômetro digital. A profundidade de cada camada foi calculada a partir da massa (18\% de fósforo), densidade $\left(2,95 \mathrm{~g} / \mathrm{cm}^{2}\right)$ e área $\left(7,06 \mathrm{~cm}^{2}\right)$ das camadas. Os resultados dos teste foram submetidos a análise de variância e a teste de Tukey. Houve um decréscimo progressivo na liberação de flúor de todas as soluções avaliadas dia após dia. Os valores correspondentes ao grupo dos compômeros foram estatisticamente superiores em relação aos demais grupos, ocorrendo as maiores taxas de liberação de flúor nas soluções desmineralizantes, evidenciando a influência do pH. Nos grupos de dentes não restaurados e restaurados com resina composta, a liberação de flúor se deu através do esmalte desmineralizado. Nas 4 camadas de esmalte mais superficiais, houve superioridade de captação no esmalte adjacente de dentes restaurados com os compômeros. Na camada mais profunda, não houve diferenças entre os grupos. O presente estudo demonstra a capacidade de liberação de flúor de restaurações de compômeros e a captação pelo esmalte adjacente, sugerindo a sua indicação em pacientes de alta atividade de cárie.

TAM; CHAN; YIM ${ }^{60}$ estudaram, em 1997, o padrão de inibição da cárie dentária inicial in vitro, testando a capacidade de liberação e recarga de flúor das restaurações de CIV convencional e os modificados por resina e, o efeito de adesivos dentinários no desenvolvimento de lesões cariosas nas superfícies e 
paredes adjacentes às restaurações de CIV modificado por resina. Foram utilizados o ChemFil Express, Vitremer, Fuji II LC, a resina composta Bis-Fil Plus e o sistema adesivo universal All-Bond 2. Os autores concluíram que o nível de liberação de flúor foi significante após 1 dia, tanto nos CIV convencional como nos modificados e essa liberação, continuou durante todo o período de teste (10 semanas). A liberação e a captação de flúor dos CIV convencional assim como dos CIV modificados por resina conferiram resistência à dentina contra o desenvolvimento de lesões recidivantes de cárie, in vitro.

ABOUSH; TORABZADEH ${ }^{1}$, em 1998, estudaram a liberação de flúor ao longo de 12 meses, de 1 cimento ionomérico convencional (Fuji Cap II), 3 cimentos ionoméricos fotoativados (Fuji II LC, Photac-Fil Aplicap, Vitremer), um compômero (Dyract) e uma resina composta com flúor (Tetric). Foram confeccionados 5 discos de cada material e imersos seqüencialmente em $4 \mathrm{ml}$ de água deionizada e mantidos em estufa a $37^{\circ} \mathrm{C}$. Nos intervalos de tempo estabelecidos, os discos eram removidos, enxaguados em $1 \mathrm{ml}$ de água deionizada, a qual era adicionada ao meio de armazenamento do disco para posterior leitura. Após secagem com seringa de ar os discos eram levados a nova solução. A solução teste contendo $2 \mathrm{ml}$ foi adicionada a $200 \mu \mathrm{l}$ de de ácido clorídrico $0,1 \mathrm{~mol} / \mathrm{l}$ para atingir ao $\mathrm{pH} 2,0$. A quantidade de flúor liberada foi determinada por um sistema de eletrodo íon sensível calibrado com soluções padrão (1 e $10 \mu \mathrm{mol} / \mathrm{l})$ preparadas por diluição de solução de $\mathrm{NaF}$ a $0,1 \mathrm{~mol} / \mathrm{l}$. A liberação de flúor dos materiais restauradores ocorre por 2 mecanismos: dissolução do material e difusão iônica, onde o íon flúor se liga a um outro íon contrário e específico, principalmente o íon sódio ou por troca iônica com grupos 
hidroxilas através do meio aquoso. Os autores concluíram que a liberação de flúor foi maior no $1^{\circ}$ dia, declinando rapidamente no dia seguinte e gradualmente nos dias subseqüentes para níveis constantes, embora o tempo para atingir esses níveis foi diferente em todos os materiais testados. Todos os CIV fotoativados liberaram mais flúor que o compômero (Dyract) ou a resina composta (Tetric). Entretanto, a quantidade de flúor liberada pelo compômero foi semelhante à liberada pela resina composta. Esse resultado mostra que, considerando a propriedade de liberação de flúor, o compômero comporta-se mais como uma resina composta do que como um CIV.

Em 1998, BILGIN; OZALP ${ }^{9}$ avaliaram a liberação de flúor de três CIV durante 28 dias em saliva artificial e posteriormente, após exposição em solução de fluoreto de sódio ou gel de flúor fosfato acidulado durante 20 dias. A capacidade de liberação de flúor dos CIV já é largamente comprovada, sendo que a maior liberação ocorre nas primeiras 24 horas e que cai posteriormente para níveis baixos, tornando-se constante após algumas semanas. O conteúdo de flúor e a sua capacidade de liberação porém diferem entre os materiais. Foram então utilizados um CIV convencional (Kromoglass), um CIV fotoativado (Vitrabond) e uma resina modificada por poliácidos (Dyract). Foram confeccionadas 10 amostras de cada material, na forma de discos, medindo $6 \mathrm{~mm}$ de diâmetro e $1,5 \mathrm{~mm}$ de altura, e mantidas em estufa a $37^{\circ} \mathrm{C}$ por 1 hora. Em seguida, cada amostra foi suspensa em $2 \mathrm{ml}$ de saliva artificial e estocada a $37^{\circ} \mathrm{C}$. As soluções eram trocadas diariamente no período de 28 dias. Nos períodos de 24 horas, 3, 7, 14 e 28 dias de estocagem, igual volume da solução tampão (TISAB) foi adicionada à solução teste, para medir a quantidade de flúor liberada, 
utilizando a combinação de eletrodo flúor seletivo e um analisador de íon digital. Após tratamento estatístico, os autores também concluíram que a maior liberação de flúor ocorreu após 24 horas. A análise estatística mostrou que o Kromoglass liberou a maior quantidade de flúor em relação aos outros materiais, seguido pelo Vitrabond e pelo Dyract e a diferença entre os grupos, a partir do $3^{\circ}$ dia, não foi estatisticamente significante.

BUZALAF; TAGA; SOUTO ${ }^{10}$, em 1998, compararam a liberação de flúor a partir de resinas compostas com e sem adição de hidroxiapatita (HA), baseado no fato de que o flúor pode sofrer um processo de adsorção na $\mathrm{HA}$ e pode manter sua liberação por um longo período de tempo. Foram utilizadas 2 resinas compostas, às quais foram adicionadas $\mathrm{F}$ e HÁ. Na Z100, um grupo recebeu flúor e outro $\mathrm{F}$ e HA e ; na Heliomolar, um grupo sem adição de HA e outro com adição de HA, que não recebeu adição de flúor por ser uma resina fluoretada. Foram confeccionados 6 espécimes para cada condição experimental, e mantidos suspensos individualmente, em $25 \mathrm{ml}$ de água deionizada e conservados em estufa a $37^{\circ} \mathrm{C}$, durante todo o experimento. A concentração de $\mathrm{F}$ foi medida diariamente durante 2 semanas e depois, semanalmente até completar 56 dias, por meio de equipamento previamente calibrado com soluções padrão de fluoreto de sódio de 1, 10, $100 \mathrm{ppm}$. Pelos resultados obtidos, a resina Z $100 \mathrm{com}$ adição de HA apresentou a maior liberação de flúor durante todo o experimento. A resina Heliomolar com adição de HA mostrou maior liberação de flúor até o $14^{\circ}$ dia quando essa liberação tornou-se menor, comparando-se com o grupo sem HA. O experimento mostrou que a adição de HA e $F$ à resina composta 
promoveu um padrão de liberação de $\mathrm{F}$ mais desejável durante o período experimental.

CARVALHO; CURY'13, em 1998, determinaram o nível de liberação de flúor de materiais restauradores, em condições que simulassem o processo de cárie. Foram utilizados os materiais Chelon-Fil (CIV), Vitremer (CIV modificado por resina), Dyract, Variglass (resina composta modificada por poliácidos) e Tetric (resina composta); 3 meios de imersão: água deionizada, saliva artificial e solução para ciclagem de pH (solução desmineralizante pH 4,3 e solução remineralizante $\mathrm{pH}$ 7). Foram elaboradas 18 amostras de cada material em forma de discos, medindo $8,6 \mathrm{~mm}$ de diâmetro e $1,65 \mathrm{~mm}$ de espessura, que foram imersas individualmente em $2 \mathrm{ml}$ de cada solução, distribuídas em 6 para cada meio. Durante 15 dias as soluções foram trocadas diariamente com intervalos variando de acordo com o meio de imersão. A cada 24 horas, quando em água deionizada e saliva artificial. No experimento em ciclagem de $\mathrm{pH}$, os espécimes permaneciam 6 horas em solução desmineralizante e 18 horas em solução remineralizante, completando o ciclo de 24 horas. A dosagem da concentração de flúor das soluções teste foi obtida com a adição de igual volume de uma solução TISAB II utilizando-se de um eletrodo específico acoplado a um analisador digital de íon, previamente calibrado com soluções padrão e em TISAB II a $50 \%$. Os resultados da concentração de flúor foram transformados na quantidade de flúor liberado pela área da amostra de material $\left(\mu \mathrm{g} / \mathrm{cm}^{2}\right)$. Os autores concluíram que o padrão qualitativo da liberação foi semelhante para todos os cinco materiais. A maior quantidade de flúor liberada ocorreu em solução de ciclagem de pH e a mais baixa em saliva artificial. A mais alta taxa de 
liberação total de flúor em saliva artificial e sistema de ciclagem de pH ocorreu com o Vitremer, seguido de Chelon-Fil, Dyract, Variglass e Tetric; mas, esta ordem foi modificada em água deionizada, tendo o Chelon-Fil liberado maior quantidade, seguido de Vitremer, Variglass, Dyract e Tetric. A concentração de flúor liberada foi maior nas primeiras 24 horas e declinou rapidamente no segundo dia, continuando a diminuir gradualmente a um nível quase constante, para cada material. Os dados sugerem que o grau de liberação de flúor dos diferentes materiais dentários varia quando são usados diferentes meios de imersão.

DIONYSOPOULOS et al. $^{18}$ avaliaram, em 1998, a capacidade de liberação de flúor do CIV modificado por resina (Vitremer), da resina modificada por poliácidos (Dyract ) em comparação com a resina composta (Silux Plux) e o CIV convencional (Fuji II). Os materiais sofreram termociclagem e foram submetidos ao desafio cariogênico por meio de gel contendo $10 \%$ de metilcelulose e 0,1M de ácido lático com pH 4,5 para formar lesões cariosas. Após 5 semanas, os espécimes foram seccionados e examinados com luz polarizada. Os resultados mostraram que o uso de CIV ativados por luz e/ou de compômero pode prevenir cáries secundárias em esmalte e dentina ao redor da restauração, como também lesões de cáries iniciais na superfície do esmalte adjacente às restaurações.

DONLY; GRANDGENETT ${ }^{19}$ avaliaram, em 1998, a inibição da desmineralização da dentina adjacente às restaurações com cimento de ionômero de vidro modificado por resina (Vitremer), 2 compômeros (Compoglass, Dyract) e a resina composta P 50, como controle. Foram utilizados 40 dentes com preparos 
classe $V$ na face mesial, restaurados e armazenados em saliva artificial (hipersaturada com cálcio e íons fosfato) por 30 dias e, então, expostos à solução promotora da cárie artificial ( $\mathrm{pH} 4,4)$ por 5 dias. Os cortes foram analisados por meio de microscópia de luz polarizada quanto à presença ou não de zona de inibição. Com os materiais Compoglass, Dyract e Vitremer, a área desmineralizada adjacente à restauração foi significantemente menor quando comparada com a utilização da resina composta. Nos dentes restaurados com compômero ou resinas não fluoretadas, não foi observada zona de inibição, embora essa zona tenha sido encontrada em $70 \%$ dos dentes restaurados com cimento de ionômero de vidro.

EICHMILLER; MARJENHOFF ${ }^{23}$, em 1998, realizaram uma revisão de literatura sobre materiais restauradores que liberam flúor. Nos anos 40, os dentistas começaram a observar que restaurações de cimento de silicato não apresentavam cáries secundárias, como costumavam ocorrer com outros materiais. A propriedade de estabilidade dimensional, indiscutivelmente era um fator importante nesse material restaurador mas, foi o efeito dos fluoretos presentes na sua composição que promoveram a maior credibilidade ao material. $\mathrm{Na}$ metade dos anos 80 , uma grande quantidade de materiais restauradores liberadores de flúor foram colocados à disposição dos dentistas e seus pacientes, e o efeito cariostático dos íons de flúor na prevenção das cáries de esmalte foi demonstrado em vários estudos. Este trabalho revisa muitas das pesquisas conduzidas sobre liberação de flúor em diversos materiais, como: amálgama contendo fluoretos, cimentos de ionômero de vidro, resinas compostas, adesivos, selantes, "liners", resinas acrílicas e materiais adesivos para brackets 
ortodônticos. Numerosos estudos laboratoriais têm avaliado a liberação de flúor de materiais restauradores, a recaptação de fluoretos pelo esmalte e a dentina e o efeito do flúor na inibição do processo de desmineralização. Entretanto, os autores enfocam a necessidade de padronização dos métodos para avaliar a liberação de flúor, como também estudos clínicos controlados sobre materiais com cinética bem caracterizada da liberação de flúor através de pesquisas complementares.

Numa revisão sobre os materiais com capacidade de liberar flúor, FARAH; POWERS ${ }^{25}$ abordaram, em 1998, a capacidade do flúor de melhorar a remineralização pelo aumento do crescimento de cristal na produção de fluoropatita com menor solubilidade comparada a apatita carbonada original e, consideraram os cimentos híbridos de ionômero de vidro modificados por resinas (Fuji II LC, Photac-Fil Quick e Vitremer) como materiais com boa capacidade de liberação de flúor, recarga e durabilidade clínica. Os compômeros (Dyract, F 2000, Compoglass e Hytac) estão sendo continuamente melhorados para possibilitar maior liberação, e também com melhores propriedades mecânicas. Os compômeros contêm carga inorgânica e monômeros modificados capazes de liberar flúor. O Dyract AP contém carga de estrôncio-flúor-alumino-silicato de vidro; o Compoglass F é composto de flúor-silicato de bário e itérbio trifluorado; o Hytac F contém itrium trifluorado e flúor-silicato de zinco-alumínio e cálcio; e o F 2000 apresenta flúor-alumino-silicato de vidro com carga e diluente hidrofílico que facilita o transporte de água e a liberação do íon. O compômero absorve água após a sua inserção e em contato com a saliva, mecanismo importante para a transferência do íon flúor. As resinas compostas que liberam flúor contêm carga 
composta de fluoreto disperso na matriz de resina. O Tetric Ceram tem duas fontes de fluoreto: Itérbio trifluorado e vidro de bário-flúor-alumino-silicato.

Considerações sobre os cimentos de ionômero de vidro e materiais híbridos com capacidade de liberação de flúor foram levantadas em 1998, por FORSTEN ${ }^{27}$. Dentre os aspectos discutidos, o autor ressaltou o efeito do flúor destes materiais restauradores, sua composição e participação na liberação de flúor, além da quantidade necessária para apresentar efeito clínico real e aplicação como materiais conservativos. Destacou os estudos laboratoriais quanto à liberação e recarga de flúor e experiências clínicas. Os materiais liberadores de flúor, de forma geral, apresentam um alta liberação inicial, diminuindo drasticamente com o tempo, e mantendo-se em níveis estáveis ao longo do tempo. Esta liberação tem efeito na remineralização de dentina subjacente, como do esmalte adjacente da estrutura dentária. A maior atividade corresponde aos períodos iniciais do endurecimento do cimento de ionômero de vidro. Isto, porque esta liberação está intimamente ligada ao processo de endurecimento do material, mas não interfere nas propriedades físicas do material. Entretanto, em materiais em que o flúor é apenas adicionado a sua composição, a liberação é bem menor, caso contrário, enfraqueceria o material, como é o caso de resinas compostas que liberam flúor e resinas compostas modificadas por poliácidos. O autor conclui que a propriedade anticariogênica e remineralizante dos cimentos ionoméricos está relacionada à liberação de flúor, com evidências clínicas e laboratoriais. A atividade de cárie do paciente e o tipo de cavidade são importantes fatores na determinação da escolha do material restaurador a ser aplicado. 
GEURTSEN $^{33}$, em 1998, elaborou uma revisão de pesquisas que identificaram as substâncias liberadas de resinas compostas e CIV. Muitas delas têm revelado que alguns componentes, como monômeros residuais, produtos de degradação de resinas compostas ou CIV são liberados no meio bucal, após a polimerização. Essas substâncias podem influenciar a biocompatibilidade e as propriedades mecânicas da restauração. Essa liberação pode ocorrer por 2 mecanismos: eluição dos monômeros livres e /ou aditivos por solventes, após o endurecimento; produção de componentes lixiáveis por degradação ou erosão ao longo do tempo. As informações disponíveis sobre a liberação de substâncias dos CIV e compômeros estão relacionadas ao flúor, em sua maioria. O tipo de solvente utilizado pode interferir na liberação de íons. Essa revisão concluiu que os CIV liberam quantidades consideráveis de fluoretos em meio aquoso e ainda que, o meio de estocagem tem influência no nível de liberação notando-se um decréscimo nos primeiros períodos e atingindo níveis constantes ao longo do tempo. Outra característica observada é a capacidade de absorção de flúor pelo material a partir de outras fontes.

GROBLER et al. ${ }^{36}$, em 1998, determinaram a liberação de flúor in vitro de 4 CIV moificados por resina (Fuji II LC, Vitremer, Enforce \& Advance), 1 compômero (Dyract) e um agente adesivo (OptiBond sobre a resina Z 100). A liberação de flúor foi medida utilizando eletrodo específico e um potenciômetro aferido em solução tamponada 50\% (TISAB com CDTA), fluoretada com 0,05 a 5 ppm. Os resultados foram analisados pelos testes estatísticos ANOVA e KruskallWallis. Os autores concluíram que todos os materiais liberaram flúor sendo a liberação mais intensa na primeira semana, principalmente nas primeiras 24 
horas. O Vitremer foi o que mais liberou, seguido do Fuji II LC e do OptiBond. O material Advance apresentou aumento de liberação de flúor, após 300 dias, provavelmente devido ao tempo de exposição à água e ao mecanismo de difusão, resultando na liberação em massa. Este mecanismo permite uma liberação lenta, sem deterioração das propriedades físicas do material.

HICKEL et al. ${ }^{38}$, em 1998, relataram sobre os novos materiais restauradores diretos, o futuro e o momento atual numa abordagem sobre composição química, propriedades e classificação. Os autores agruparam os materiais restauradores em estéticos e metálicos, em diretos e indiretos (inlay/onlay). Para os CIV e os compósitos sugeriram dois subgrupos: CIV que contem água e compósitos, para aqueles que não contêm água. No primeiro grupo encontram-se o CIV convencional, CIV reforçado com metal (cermet), CIV altamente viscoso, ionômeros híbridos (ionômeros modificados por resina) e, no grupo dos compósitos, os compósitos convencionais, compósitos de micro partículas, compósitos híbridos e os compômeros (resinas modificadas por poliácidos). Entre os materiais restauradores estéticos diretos aparece um nova classe de material o "ormocer", abreviatura de "organically modified ceramics". Esse estudo foi aprovado na comissão de projetos da FDI (Federation Dental Assosciation).

KAWAl et al. ${ }^{44}$ estudaram, em 1998, a quantidade de liberação de flúor de 3 resinas compostas (FluorEver, FluoroCore, Pertac-Hybrid) e a capacidade de captação de flúor pelo esmalte e cemento. Os autores concluíram que a quantidade de flúor absorvido por esses tecidos está relacionada com a 
quantidade de flúor liberada por essas resinas compostas. Parte da quantidade desse flúor movimenta-se na camada híbrida através da água e a outra parte é direcionada à superfície das restaurações que já absorveram água do ambiente bucal e posteriormente transferida para as áreas de esmalte adjacentes a elas.

KRAFT et al. ${ }^{46}$, em 1998, estudaram o efeito da resina composta Charisma, do compômero Dyract e do cimento de ionômero de vidro convencional Ketac-Fil sobre a desmineralização no esmalte e dentina subjacentes às restaurações. Os dentes restaurados com resina composta apresentaram pronunciado número de lesões no esmalte e na dentina (90\%), e que foram em menor número nos dentes restaurados com compômeros. Com o cimento de ionômero de vidro não houve formação de lesões cariosas em esmalte e em dentina. Os autores concluíram que o Ketac-Fil confere alta proteção à desmineralização ácida, enquanto o Dyract apresentou baixo efeito inibidor e a resina composta Charisma não foi capaz de prevenir a formação de cárie.

LEVALLOIS et al. ${ }^{47}$, em 1998, estudaram a liberação de flúor in vitro de materiais restauradores em água versus saliva artificial. Foram utilizados CIV modificados por resina (Fuji II LC, Vitremer) e um compômero (Dyract). Os autores concluíram que o Vitremer liberou significantemente mais flúor do que o Fuji II LC, seguido do Dyract, tanto em água destilada quanto em saliva artificial. Estes resultados foram justificados pela presença de uma camada insolúvel de $\mathrm{CaF}_{2}$, precipitado na superfície do material, proveniente do $\mathrm{Ca}^{++}$presente na solução de saliva artificial, formando uma barreira física para liberação de fluoreto. 
A presença de cálcio nos materiais foi confirmada pela microscopia eletrônica de varredura.

$\mathrm{McCABE}^{48}$, em 1998, através de uma revisão sobre os CIV modificados por resina, estabelece uma classificação de acordo com as reações desencadeadas durante a reação de presa, as alterações dimensionais, as propriedades mecânicas, a adesão à estrutura dentária e a liberação de flúor, maior vantagem do material, embora os fabricantes raramente enfatizem os seus efeitos terapêuticos. Neste sentido, os materiais foram subdivididos em: compostos modificados, que endurecem pelo mecanismo de polimerização, mas contendo íons lixiáveis em compostos vitrosos para que possam promover a liberação de flúor (Variglass); produtos do tipo híbridos, endurecem por uma reação ácido-base e por polimerização (ativada por luz ou química), contêm componentes tanto das resinas como dos ionômeros (Fuji II Lc, Vitremer); e compômeros, fornecidos sob a forma de pasta única com todos os componentes da resina e do ionômero, exceto a água (Dyract). A literatura sugere ser a liberação de flúor dos híbridos semelhante à do ionômero convencional. As resinas com liberação de flúor e as resinas modificadas por poliácidos liberam menores quantidades de flúor, embora a longo prazo a liberação de flúor dos ionômeros modificados por resina seja semelhante à dos compômeros.

Em 1998, SMALL et al. ${ }^{56}$ estudaram a sorção de água do compômero Dyract, da resina híbrida Herculite XRV e do ionômero modificado por resina Fuji II LC. Os autores concluíram que os compômeros e os materiais à base de resina absorveram água lentamente durante os 6 meses, alcançando um volume 
absorvido de $3 \%$ e 1,3\% respectivamente, enquanto o ionômero modificado por resina alcançou 9,3\% e o ionômero convencional 5,3\% absorvendo assim, as maiores quantidades de água.

Em 1998, SHAW; CARRICK; McCABE ${ }^{55}$ avaliaram a liberação diária de flúor de 2 CIV (Ketac-Fil e ChemFil Superior) e 2 compômeros (Compoglass e Dyract Restorative) durante 6 meses. Inicialmente foi avaliado o tempo para as soluções alcançarem a estabilização. Esse equilíbrio ocorreu em 48 horas para todos os materiais. Os autores concluiram que os espécimes estocados em água atingem um equilíbrio rapidamente, sugestionando que o ritmo em que a solução estoque é trocada pode alterar as taxas relativas de liberação de flúor dos materiais, fato este sempre negligenciado. A liberação dos CIV é inicialmente maior que a dos compômeros, caindo rapidamente e atingindo níveis semelhantes aos compômeros. Os compômeros não produzem nenhuma explosão inicial de flúor e os níveis de liberação permanecem relativamente constantes. Até o presente, desconhece-se o que seria mais importante na prevenção da cárie, a explosão inicial ou a liberação de flúor prolongada pelos ionômeros Outro fator importante é o efeito reserva, capacidade de recarga e de voltar a liberar. Futuras pesquisas são necessárias para avaliar se os compômeros que liberam taxas relativamente baixas e sem capacidade de recarga têm o mesmo potencial para reduzir cáries que os ionômeros de vidro.

Em 1998, VERBEECK ${ }^{63}$ comparou, in vitro, a liberação de flúor dos ionômeros convencionais e dos modificados por resina. Os ionômeros convencionais atingem seu endurecimento através da reação ácido-base, 
enquanto ionômeros modificados por resina endurecem através de reação de polimerização e de reação ácido-base e os compômeros, apenas através da reação de polimerização, embora apresentem alguns componentes do ionômero de vidro. Neste estudo a liberação de flúor do ionômero convencional (Ketac Fil ), dos ionômeros modificados por resina (Vitrebond, Photacbond), do compômero (Dyract) e da Resina Composta (Orthon), foi expressa em $\mathrm{mg} / \mathrm{cm}^{2}$. Os autores concluíram que em função do tempo, a liberação cumulativa de flúor do cimento ionômero de vidro e o ionômero modificado por resina diferiu marcadamente dos compômeros e das resinas compostas que liberaram, consideravelmente, menores quantidades de flúor. As quantidades de flúor liberadas após 24 horas do Vitrebond foram de $0,1 \mu \mathrm{g} / \mathrm{cm}^{2}$, do Photac bond, $0,08 \mu \mathrm{g} / \mathrm{cm}^{2}$, do Ketac Fil, $0,17 \mu \mathrm{g} / \mathrm{cm}^{2}$ e do Dyract $0,001 \mu \mathrm{g} / \mathrm{cm}^{2}$ de flúor. O mecanismo de liberação de flúor do ionômero de vidro tem como base as fontes de flúor, tais como as partículas de vidro, o gel de sílica que recobre as partículas de vidro e a matriz de polissais, onde os íons de flúor podem estar unidos por fortes ligações formando complexos com os íons metálicos, especialmente o alumínio, e por fim no poro líquido onde os íons fluoreto estão unidos ou livres para movimentar-se e formar ligações. Após 7 dias a liberação de flúor do Dyract é a mesma, enquanto os demais materiais diminuíram sua liberação com o tempo (Photac fil, 0,06 $\mu \mathrm{g} / \mathrm{cm}^{2}$, Vitrebond $0,08 \mu \mathrm{g} / \mathrm{cm}^{2}$, Ketacfil, $1,2 \mu \mathrm{g} / \mathrm{cm}^{2}$ ). Nos compômeros, as partículas de vidro não são facilmente degradadas pela água resultando numa significante liberação de flúor. A taxa de liberação diminui com o tempo, como resultado do desenvolvimento da camada de sílica gel, cobrindo as partículas de vidro, entretanto esta camada não funciona como um reservatório de flúor, agindo como 
uma barreira que impede a liberação do flúor das partículas de vidro remanescentes, demonstrando assim que as fontes de flúor estão relacionadas à matriz orgânica dos materiais. Os cimentos de ionômeros de vidro modificados ou não, funcionam como membranas com permeabilidade cátion-seletiva e por isso o transporte de flúor através do cimento de ionômero de vidro não ocorre apenas por simples difusão e depende do tempo de maturação. Este efeito da maturação do material sobre a liberação de flúor é provavelmente o resultado da perda de formas iônicas de flúor relativamente solúveis provocando alterações na constituição da matriz, o mesmo não acontece com as resinas compostas ou com os compômeros

XU; BURGESS ${ }^{66}$ estudaram em 1998, a liberação de flúor e a resistência à compressão dos materiais com capacidade de liberar esse íon. Foram analisados 10 materiais (Fuji XI, Ketac Molar, Vitremer, Photac-Fil, Fuji II LC Imp, Compoglass, F-2000, Dyract AP, Hytac, Tetric-Ceram). Todos os materiais liberaram quantidades menores de flúor em função do tempo. Os cimentos de ionômero de vidro convencionais e os modificados por resina liberaram maiores quantidades de flúor comparados aos compômeros (Dyract AP e Compoglass). De maneira geral, os materiais com alta liberação de flúor apresentaram baixa resistência à compressão.

Em 1999, ATTIN et al. ${ }^{5}$ testaram a capacidade de liberação e captação de flúor, em soluções tampão neutra e ácida, em resinas compostas modificadas por poliácidos, os chamados compômeros, (Dyract, Compoglass) e 1 cimento de ionômero de vidro convencional (GIC Vivaglass Base) como grupo controle. 
Foram confeccionados 40 espécimes de cada material, 20 deles foram imersos em $5 \mathrm{ml}$ saliva artificial $(\mathrm{pH}$ 6,4) por 5 minutos e os outros 20 em dentifrício fluoretado fluido contendo $5 \mathrm{ml}$ de saliva artificial (ph 5,4) por 5 minutos. Após lavagem em água destilada e secagem com papel absorvente, 10 espécimes fluoretados e 10 não fluoretados foram imersos em $3 \mathrm{ml}$ de solução tampão neutra $(\mathrm{pH} 6,8)$ a $37^{\circ} \mathrm{C}$ e os restantes foram estocados em solução ácida (pH 4,0). Em intervalos de 1, 2, 3, 4 e 5 dias, os grupos recebiam esse tratamento e eram transferidos para novas soluções neutra ou ácida. As soluções testadas foram tamponadas com igual volume de TISAB II (ORION) e a quantidade de flúor foi medida através de um eletrodo sensível ao flúor e os valores convertidos para $\mu \mathrm{gF} / \mathrm{cm}^{2}$. Em todos os materiais testados, foi observada a liberação de flúor declinando durante todo o experimento, e significantemente maior no meio ácido comparada com a da solução tampão neutra. Os espécimes que foram tratados com dentrifrício fluoretado fluido apresentaram maiores concentrações de flúor liberado nos de cimento de ionômero de vidro convencional, o que não ocorreu com os compômeros, concluindo os autores que, o Dyract e Compoglass não tem capacidade de reincorporar flúor, independentemente do valor do $\mathrm{pH}$ do meio.

BELL et al. ${ }^{7}$ investigaram in vitro, em 1999, o efeito da saliva na formação de película adquirida na liberação de flúor do CIV, Chemfil Superior, ao longo de 20 dias. Foram confeccionados discos de CIV medindo $6 \mathrm{~mm}$ de diâmetro e 1,5 mm de espessura e divididos em dois grupos, de acordo com o meio de imersão usado na liberação de flúor. O grupo controle em água deionizada e o grupo teste em saliva. 10 espécimes eram imersos, diariamente em $1 \mathrm{ml}$ de saliva por 10 minutos e outros 10 durante 1 hora. $\mathrm{O}$ grupo controle 
recebia o mesmo tempo de tratamento. Em seguida eram lavados em pequena quantidade de água e imersos em $2 \mathrm{ml}$ de água deionizada para completar o período de 24 horas. Após as trocas diárias das soluções, $1 \mathrm{ml}$ de cada uma delas era removida e estocado a $20^{\circ}$ C para avaliação posterior da liberação de flúor. Os resultados mostraram que a maior liberação ocorreu no $1^{\circ}$ dia, 14,5 $\mu \mathrm{g} / \mathrm{cm}^{2}$ no grupo controle e $13,3 \mu \mathrm{g} / \mathrm{cm}^{2}$ grupo teste, declinando acentuadamente no $2^{\circ}$ dia, atingindo valores quase constantes, no $10^{\circ}$ dia e continuou liberando em níveis baixos até o 20 dia. Os autores concluíram que a liberação de flúor foi ligeiramente maior na água deionizada, indicando que a saliva retarda essa liberação, no CIV mesmo quando os espécimes do grupo teste foram imersos subseqüentemente na água comparados com os do controle que utilizaram apenas água deionizada. Este fato foi sugestivo aos autores de que os depósitos salivares foram formados em poucos minutos, logo após a imersão do material na saliva.

Em 1999, BERTACCHINI et al. ${ }^{8}$ estudaram o grau de solubilidade dos ionômeros e compômeros em relação à quantidade de flúor liberada em função do tempo. Neste estudo foram avaliados os ionômeros convencionais (Fuji IX, Vivaglass Fil, Vivaglass Cem), ionômeros modificados por resina (Advance, Fuji Duet, Vitremer luting) e os compômeros (Dyract e Compoglass). A liberação foi medida em $\mu \mathrm{g} / \mathrm{cm}^{2}$ no período de 1 hora, 24 horas, 7, 15, 30, 60 e 90 dias. Os autores demonstraram que a quantidade de flúor liberada aumentou entre 24 horas e 07 dias, em todos os materiais testados, e após 15 dias da imersão, esses valores foram menores em 6 produtos e somente 2 materiais continuaram com alta concentração de flúor liberada (Vivaglass Cem e Compoglass). Após 30 
dias, todos os valores estabilizaram-se, exceto para Vivaglass Cem. Em todos os materiais, a solubilidade aumentou em função do tempo. A liberação de flúor dos compômeros foi significantemente menor que dos ionômeros e ainda, o Compoglass liberou maior quantidade de flúor que o Dyract, embora a diferença não tenha sido estatisticamente significante. Os ionômeros convencionais liberaram as maiores quantidade de flúor, sendo que o Fuji IX liberou menos que o Vivaglass Cem e Vivaglass Fil. Os ionômeros convencionais mostraram maior solubilidade que os ionômeros híbridos, mas o Fuji IX foi o ionômero convencional que apresentou valores significantemente mais baixos, devido às diferenças na composição e/ou na proporção pó/líquido. Uma análise global das determinações de liberação de flúor e da solubilidade indica que grande corrosão está geralmente associada a possibilidade de maior liberação de flúor do material.

CARVALHO; CURY' ${ }^{12}$ em 1999, preocupados com as condições laboratoriais na investigação da liberação de flúor de diversos materiais odontológicos, propõem um modelo de simulação de ciclagem de pH, associando uma solução desmineralizante $(\mathrm{pH} 4,3)$ a uma remineralizante $(\mathrm{pH} \mathrm{7,0)}$. Para efeitos comparativos, a água deionizada e uma saliva artificial correspondem a dois meios de imersão para quantificação da liberação de flúor. Foram avaliados um cimento de ionômero de vidro (Chelon-Fil), resinas compostas modificadas por poliácidos (Dyract, Variglass), um cimento de ionômero de vidro modificado por resina (Vitremer) e uma resina composta (Tetric), obtendo-se 18 corpos-de-prova por material, com dimensões de 8,6 mm de diâmetro por 1,65 mm de espessura, sendo igualmente distribuídos nos 3 meios considerados. Foram seguidas as instruções dos fabricantes e realizada uma proteção superficial com vaselina. 
Após 24 horas em estufa, os corpos-de-prova foram polidos com discos Sof-lex sob refrigeração e posteriormente armazenados em $2 \mathrm{ml}$ dos meios de imersão, suspensos com fio dental. Em 15 dias, a cada 24 horas era realizada troca de solução, sendo que para o sistema cíclico de pH, permanecia-se 6 horas em solução DES e 18 horas em solução RE. As leituras foram procedidas utilizandose um eletrodo e o medidor de $\mathrm{pH}$ digital Orion e TISAB, este na mesma proporção do material de leitura. Todos os materiais apresentaram mesmo padrão de liberação de flúor $\left(\mu \mathrm{gF} / \mathrm{cm}^{2}\right)$ no período considerado, isto é, maior no 1ำ dia, declinando no dia seguinte e se estabelecendo em níveis mais baixos e constantes no restante do período. Em saliva artificial houve a menor taxa de liberação de flúor, sendo maior quando da realização da ciclagem de pH. Neste meio, a liberação foi decrescente nesta ordem: Vitremer, Chelon-Fil, Dyract, Variglass e Tetric. Os achados sugerem que a liberação de flúor está na dependência do meio utilizado na avaliação.

FRANCCI et al. ${ }^{31}$ avaliaram, em 1999, os efeitos da liberação de flúor de vários materiais restauradores adesivos na resistência dentinária à desmineralização e no metabolismo bacteriano em um sistema modificado in vitro. Cavidades padronizadas foram preparadas em dentes bovinos e restauradas com sistemas restauradores adesivos, utilizando como materiais retauradores, o Z 100, Tetric Ceram com Single Bond e com Fuji Bond LC; cimento de ionômero de vidro modificado por resina e cimento de ionômero de vidro convencional. A liberação de flúor dos dentes restaurados foi avaliada. Durante as primeiras 24 horas, os dentes foram submetidos à ação do ácido láctico por 3 horas para medir a liberação de cálcio. Outros dentes foram estocados em água deionizada e 
expostos a uma suspensão de $S$. mutans por 6 horas para medir a liberação de cálcio e o pH. Os autores concluíram que a liberação de flúor melhorou a resistência dentinária, mas não inibiu a produção ácida do S. mutans

GEURTSEN, LEYHAUSEN, GARCIA-GODOY ${ }^{34}$, em 1999, avaliaram a liberação de flúor e a microdureza superficial de 4 resinas modificadas por poliácidos, (Compoglass F, F 2000, Dyract AP, e um compômero experimental.), após armazenamento em água e em várias soluções tampão salivares, incluindo um tampão de esterase. As soluções apresentavam diferentes níveis de pH: tampão ácido (I), pH 4,2; tampão neutro (II), pH 7,0; tampão neutro (III), igual ao tampão (II) com $40 \mathrm{mU} / \mathrm{ml}$ de esterase que é equivalente à atividade de hidrolases na saliva humana. Essas soluções eram trocadas a cada 48 horas. Para avaliar a microdureza Vickers, os espécimes dos materiais foram armazenados secos a 37ํㅡ. Houve variação da quantidade de fluoreto liberado nos quatro materiais, sendo a mais alta no tampão ácido (I). O Dyract também liberou quantidades semelhantes de fluoreto tanto na água deionizada quanto na solução com pH 4,2. Outro dado citado pelo autor é que as resinas modificadas por poliácidos podem liberar flúor de componentes incluídos na matriz resinosa, como do fluoreto de itérbio, bem como das cargas de vidro, fluor-alumino-silicato de vidro, fluoreto de estrôncio.

HEINTZE $^{37}$, em 1999, descreve sobre o processo da instalação da cárie e como materiais restauradores podem inibir a formação de cárie secundária. Segundo o autor a maior parte desses materiais libera flúor e que deveria impedir o desenvolvimento da cárie. Os estudos, em sua maioria, são 
realizados em laboratório, portanto de significância limitada e, a maior parte deles concluiu que a liberação é apenas temporária. O autor realizou um estudo in vitro sobre o Ariston pHc, resina composta com liberação de flúor, por meio de um modelo microbiano artificial simulando o meio bucal. Foi demonstrado que são liberados mais íons em um ambiente ácido $(\mathrm{pH} 4,0)$, que em ambiente neutro $(\mathrm{pH}$ 6,8). A taxa que o flúor é liberado é menor que aquela dos cimentos de ionômeros de vidro convencionais mas, superior a dos compômeros. O material apresentou também, o mesmo padrão de liberação de flúor, um pico nos primeiros meses. O autor relata que após o primeiro mês, esse material tende a se estabilizar em um nível de aproximadamente $1 \mu \mathrm{gF}^{-} / \mathrm{cm}^{2}$, . Resultados de 2 anos de testes indicam que o íon flúor ainda está presente. Investigações in vitro e in vivo para determinar a influência dessa liberação nas propriedades físicas do material, ainda não foram concluídas.

PRESTON et al. ${ }^{53}$, em 1999, compararam a quantidade de flúor liberada entre 2 cimentos de ionômero de vidro (Chemfil, Ketac Fil), 1 ionômero de vidro modificado por resina (Vitremer), 1 compômero (Dyract) e 1 resina composta contendo flúor (Heliomolar). em água e em saliva artificial após 01 hora, 06 horas e em 01, 02, 07, 57 e 64 dias. Os dados foram analisados para definir a relação de liberação de flúor em $\mu \mathrm{g} / \mathrm{cm}^{2} /$ hora para cada material. Os resultados apresentaram, em ambas soluções, quantidades de flúor reduzidas após 24 horas para todos os materiais, embora o nível de liberação tenha sido significantemente menor em saliva artificial que em água, mas de forma contínua durante os 64 dias. A taxa de liberação do compômero (Dyract) na água também aumentou de forma compatível com a hidratação do compômero pela saliva, que é menor, 
quando comparada com a hidratação pela água destilada. O cimento de ionômero de vidro convencional e o modificado por resina apresentaram uma taxa inicial de flúor alta, que declinou rapidamente após 48 horas, em função da dissolução parcial das partículas de vidro no ácido poliaquenóico durante a reação de endurecimento. O cimento de ionômero de vidro modificado por resina (Vitremer) apresentou o nível mais alto de flúor liberado/hora, enquanto a resina composta e o compômero apresentaram o mais baixo, em ambos os meios.

Em 1999, VIEIRA et al. ${ }^{64}$ estudaram, in vitro, a liberação de flúor do cimento de ionômero de vidro modificado por resina (Vitremer), dos compômeros (Variglass VLC e Dyract), do cimento de ionômero de vidro convencional (Chelon Fil) e da resina composta (Heliomolar Radiopaque). Os corpos de prova de cada material foram submetidos a ciclos de desmineralização e remineralização, durante 14 dias, simulando o desafio cariogênico. Foram expostos durante 8 dias, a um período de 6 horas/dia em solução desmineralizante e 17 horas/dia numa solução remineralizante. Receberam então, um tratamento adicional de imersão em 3,00 ml de água deionizada, contendo 1,00 grama de dentifrício com 1,100 ppm F (fluoreto de sódio), duas vezes ao dia por 5 minutos até o final do experimento, 14 dias. Os autores observaram que os materiais liberaram mais flúor em solução desmineralizante $(\mathrm{pH} 4,3)$ que na solução remineralizante $(\mathrm{pH}$ 7,0), exceto a resina Heliomolar, no $4^{\circ}$ e no $7^{0}$ dia. $O$ Variglass apresentou a maior liberação de flúor no $3 .^{\circ}$ dia, ao contrário dos outros materiais, que 0 fizeram no $1^{\circ}$ dia. Todos os materiais mostraram uma maior liberação de flúor nos primeiros 3 dias, declinando consideravelmente nos dias subseqüentes, atingindo concentrações quase constantes. Os autores citam que a maior 
liberação foi observada no meio ácido, o que parece favorável, na prevenção da perda mineral do esmalte, pelo flúor proveniente desses materiais, na fase em que existe um desafio cariogênico. Isto ocorre, possivelmente por dois processos: pela erosão da superfície, de forma rápida inicialmente e, num processo mais lento, pela difusão contínua dos íons do corpo do material que permanece por mais tempo. Todos os materiais estudados foram capazes de absorver flúor da solução de dentifrício e posteriormente liberá-lo de forma relativamente constante, a níveis mais altos que os observados entre $05^{\circ}$ e $07^{\circ}$ dia do experimento, quando foi observada uma tendência à estabilização da liberação, justificando a incorporação de dentifrício fluoretado a partir do $8^{\circ}$ dia.

Interessados na relação da quantidade de flúor liberada por materiais restauradores e no potencial antimicrobiano, YAP; KHOR; FOO ${ }^{68}$, em 1999, avaliaram dois compósitos (Tetric e Experimental X), dois compômeros (Dyract e Compoglass), um cimento de ionômero de vidro modificado por resina (Fuji II LC) e um cimento de ionômero convencional (Fuji II cap), este como controle positivo de liberação de flúor. Dois estudos independentes foram realizados. Na avaliação da liberação de flúor, foram obtidos 5 discos de $6 \mathrm{~mm}$ de diâmetro por 1,2mm de espessura através de um molde de teflon. A manipulação e polimerização dos materiais foi procedida conforme instruções dos fabricantes. Em seguida, permaneceram em estufa a $37^{\circ} \mathrm{C}$ e $100 \%$ de umidade por 1 hora. Após removidos da matriz, foram acondicionados individualmente em $9 \mathrm{ml}$ de água deionizada em frascos plásticos, mantidos sob constante agitação de 110 r.p.m. a $37^{\circ} \mathrm{C}$. A cada 24 horas, cada disco era lavado com $1 \mathrm{ml}$ de água deionizada e transferido para nova solução de $9 \mathrm{ml}$ de água deionizada. A quantificação de liberação de flúor foi 
mensurada por cromatografia iônica, abrangendo um período de 35 dias. A quantidade semanal e total das leituras obtidas foram submetidas aos testes estatísticos de Kruskal-Wallis, $p<0,05$. A comparação entre materiais foi realizada pelo teste de Mann-Whitney Wilcoxson, $p<0,05$. O cimento de ionômero convencional Fuji II cap liberou maior quantidade significativa de flúor, seguida do Compoglass, Fuji II LC, Dyract, Experiment X e Tetric. Os três primeiros produtos apresentaram o mesmo padrão de liberação, com grandes valores iniciais. Os compósitos não apresentaram liberação de flúor a partir do 14ํdia. Na avaliação do potencial antimicrobiano, o IRM, à base de óxido eugenol, foi utilizado como controle. Foram realizados testes em cultura de ágar, na presença de S. mutans, S. sobrinus e L. casei. Com exceção do grupo do IRM, nenhum outro grupo obteve êxito na inibição de crescimento de cultura bacteriana em nenhum dos períodos avaliados, apesar da comprovação da presença de flúor na subsuperfície do ágar. O fato do IRM promover inibição inicial se deve provavelmente à composição de óxido eugenol. Não foi encontrada correlação na hipótese lançada, isto é, não houve correlação entre a quantidade de liberação de flúor e potencial antibacteriano.

KARANTAKIS et al. ${ }^{43}$, avaliaram em 2000 , o padrão e a quantidade do flúor liberado de 3 tipos de cimento de ionômero de vidro (reforçado com metal Argion; modificado por resina, Vitremer e Fuji II LC), 1 resina composta modificada por poliácidos - compômero (Dyract) e 1 resina composta contendo flúor (Tetric). Usaram 3 meios de imersão: água destilada, saliva artificial e ácido láctico. Foram confeccionados 105 espécimes cilíndricos, 21 para cada material medindo $10 \mathrm{~mm}$ de diâmetro e 1,5 mm de espessura. Eram imersos em $7 \mathrm{ml}$ das 
soluções teste que constituíram 3 grupos: grupo I, água destilada, grupo II, saliva artificial, grupo III, ácido láctico e estocados a $37^{\circ} \mathrm{C}$. As quantidades de liberação foram medidas no decorrer de 16 semanas, em intervalos de 4, 8, 12 e 24 horas e no $2^{\circ}, 3^{\circ}, 7^{\circ}, 14^{\circ}, 2^{\circ}, 56^{\circ}$ e $112^{\circ}$ dias. Aos $7 \mathrm{ml}$ da solução teste, mais $1 \mathrm{ml}$ usado para lavar os espécimes, foram misturados $4 \mathrm{ml}$ de TISAB, solução tampão alumínio e levados para leitura em analisador para fluoretos. As soluções eram agitadas durante a análise, em agitador magnético Heidolph. Os autores concluíram que o padrão de liberação de flúor foi similar para todos os materiais. A maior quantidade de flúor liberada foi do cimento de ionômero de vidro reforçado com metal, Argion, seguido do Vitremer, Fuji II LC, Dyract e a resina composta Tetric, principalmente nas primeiras 24 horas. A liberação declinou nos dias seguintes, mas era presente em pequenas quantidades até o final do experimento. $\mathrm{O} \mathrm{pH}$ do meio interferiu fortemente na liberação. Houve diferença significante $(\mathrm{P}<0.001)$ na quantidade de flúor liberada no ácido láctico comparada com água e saliva artificial. Entretanto, não houve diferença significante $(p>0,05)$ entre água e saliva artificial.

NARVAI ${ }^{51}$ em 2000, através de uma revisão sobre a cárie dentária e o flúor, na visão do século XX aborda a história e a importância da ação do flúor no meio bucal. Desde a descoberta dos dentes manchados que a epidemiologia da cárie dentária vem sendo estudada. Ao verificarem a relação da presença de flúor nas fontes de água de comunidades, as quais apresentavam pouca cáries, que fluoretação das águas de abastecimento foi um dos maiores benefícios na prevenção e controle da cárie dentária. Relata também a descoberta da ação tópica do flúor no esmalte dentário disponibilizando produtos com esse 
mecanismo de ação, como os dentrifícios fluoretados, que agem diretamente na diminuição da solubilidade do esmalte. 
3 PROPOSIÇÃO 


\section{PROPOSIÇÃO}

Após realizar a revisão de literatura que nos pareceu importante dentro dos estudos de materiais restauradores que liberam flúor, resolvemos desenvolver um estudo in vitro que tem como objetivos:

3.1 Avaliar, por um período de 15 dias, através de testes de liberação de flúor em água e em um sistema de ciclagem de $\mathrm{pH}$, os seguintes materiais restauradores estéticos para dentes anteriores e posteriores: as resinas compostas com liberação de flúor (Ariston pHc, Tetric Ceram e Definite); a resina modificada por poliácido (Dyract AP).

3.2 Avaliar, comparativamente, a resina composta híbrida (Z100) como controle negativo e o cimento ionômero de vidro modificado por resina (Vitremer), como controle positivo. 
4 MATERIAIS E MÉTODOS 


\section{MATERIAIS E MÉTODOS}

\subsection{Materiais}

A amostra deste trabalho constou de 6 materiais restauradores que estão relacionados na Tabela 4.1. Os materiais foram distribuídos em um grupo controle e um grupo experimental.

O grupo controle foi constituído por um material sem capacidade de liberar flúor, a resina composta Z 100 como controle negativo e, um cimento de ionômero de vidro modificado por resina com capacidade de liberar flúor, o Vitremer (VIT) como controle positivo.

O grupo experimental foi constituído por quatro materiais restauradores. O Dyract (DYR); resina composta modificada por poliácidos (compômero); o TetricCeram (TET), resina composta híbrida; o Ariston pHc $(A)$, resina composta de micropartículas; o Definite (DEF), resina composta à base de cerâmica organicamente modificada.

Os materiais possuem características comuns: presença de resina em sua composição, fluoretos e sofrem também polimerização com fotoativação pela luz. 
Todos os materiais avaliados foram utilizados na cor A3 da escala VITA, para que não houvesse diferença nos graus de polimerização, exceto, o Ariston, que possui cor única.

TABELA 4.1 - Apresentação dos materiais restauradores, de acordo com sua classificação, lote e fabricantes

\begin{tabular}{clcc}
\hline \hline MATERIAL & \multicolumn{1}{c}{ CLASSIFICAÇÃO } & LOTE & FABRICANTE \\
\hline \hline Z 100 & Resina micro-híbrida e radiopaca para dentes posteriores & 9 EG & 3M Dental \\
$\begin{array}{c}\text { Vitremer }^{\text {TM }} \\
\text { (VIT) }\end{array}$ & $\begin{array}{l}\text { Cimento de lonômero de Vidro modificado por resina, } \\
\text { fotopolimerizável }\end{array}$ & 20000516 & 3M Dental \\
$\begin{array}{c}\text { Dyract AP } \\
\text { (DYR) }\end{array}$ & Compômero restaurador fotopolimerizável em cápsulas & 9908000277 & Dentsply \\
$\begin{array}{c}\text { Tetric }{ }^{\circledR} \text { Ceram } \\
\text { (TET) }\end{array}$ & $\begin{array}{l}\text { material restaurador estético para dentes anteriores e } \\
\text { posteriores }\end{array}$ & b 37704 & Vivadent \\
$\begin{array}{c}\text { Ariston pHc } \\
\text { (AR) }\end{array}$ & Material restaurador estético para dentes posteriores & AO 9633 & Vivadent \\
$\begin{array}{c}\text { Definite }{ }^{\circledR} \\
\text { (DEF) }\end{array}$ & Material restaurador estético para dentes anteriores & $\#$ & Degussa \\
\hline \hline
\end{tabular}

\# Material fornecido pelo fabricante, na forma de pontas avulsas, sem número de lote

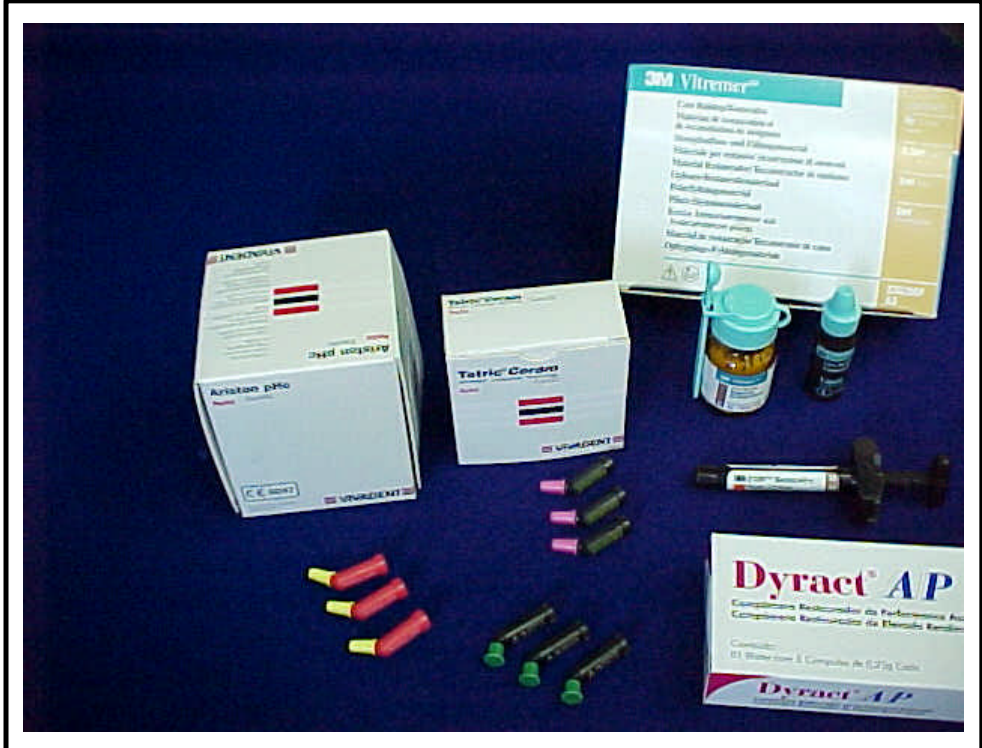

FIGURA 4.1 - Apresentação comercial dos materiais avaliados 
TABELA 4.2 - Relação dos reagentes utilizados com os respectivos fabricantes

\begin{tabular}{ll}
\hline \hline \multicolumn{1}{c}{ REAGENTE } & FABRICANTE \\
\hline \hline Ácido acético glacial & MERCK \\
Ácido clorídrico & MERCK \\
Cloreto de cálcio & MERCK \\
Cloreto de potássio & ECIBRA \\
Fosfato de potássio & MERCK \\
Hexametil-disilazano (HMDS) & SIGMA \\
Hidróxido de sódio & NUCLEAR \\
\hline \hline
\end{tabular}

\subsection{Meios de imersão}

Os meios de imersão utilizados, foram os seguintes:

I - água deionizada $\left(\mathrm{H}_{2} \mathrm{O}\right)$

II -soluções para ciclagem de pH (CpH): solução Desmineralizante (Des-) e solução Remineralizante (Re) (Des-Re), com as seguintes composições:

Des-: cálcio 2,0 mM, fosfato 2,0 mM e tampão acetato $75 \mathrm{mM}$ em pH 4,3, contendo $\mathrm{NaN}_{3} 0,02 \%$.

Re-: cálcio 1,5 mM, fosfato $0,9 \mathrm{mM}$, cloreto de potássio $150 \mathrm{mM}$ e tampão Tris $20 \mathrm{mM}$ em pH 7,0, contendo $\mathrm{NaN}_{3}$ 0,02\%. 


\subsection{Métodos}

Foram utilizados 16 corpos-de-prova para cada grupo de materiais, totalizando 96 amostras. Os corpos-de-prova de cada material foram distribuídos, individualmente, 8 em água destilada e 8 em sistema de ciclagem de pH por material.

\subsubsection{Confecção dos corpos-de-prova}

Para a confecção dos corpos-de-prova, foi utilizada uma matriz de Teflon, de forma circular com 26 mm de diâmetro e 1,5 mm de espessura, com um orifício central medindo $11 \mathrm{~mm}$ de diâmetro e 1,5 mm de altura, perfazendo $241,78 \mathrm{~mm}^{2}$ de área (Figura 4.2). Na matriz foi realizada uma fenda, para permitir a passagem de fio dental, necessário para manter o corpo de prova suspenso nos meios de imersão, preso à tampa do recipiente de armazenamento (Figura 4.2).

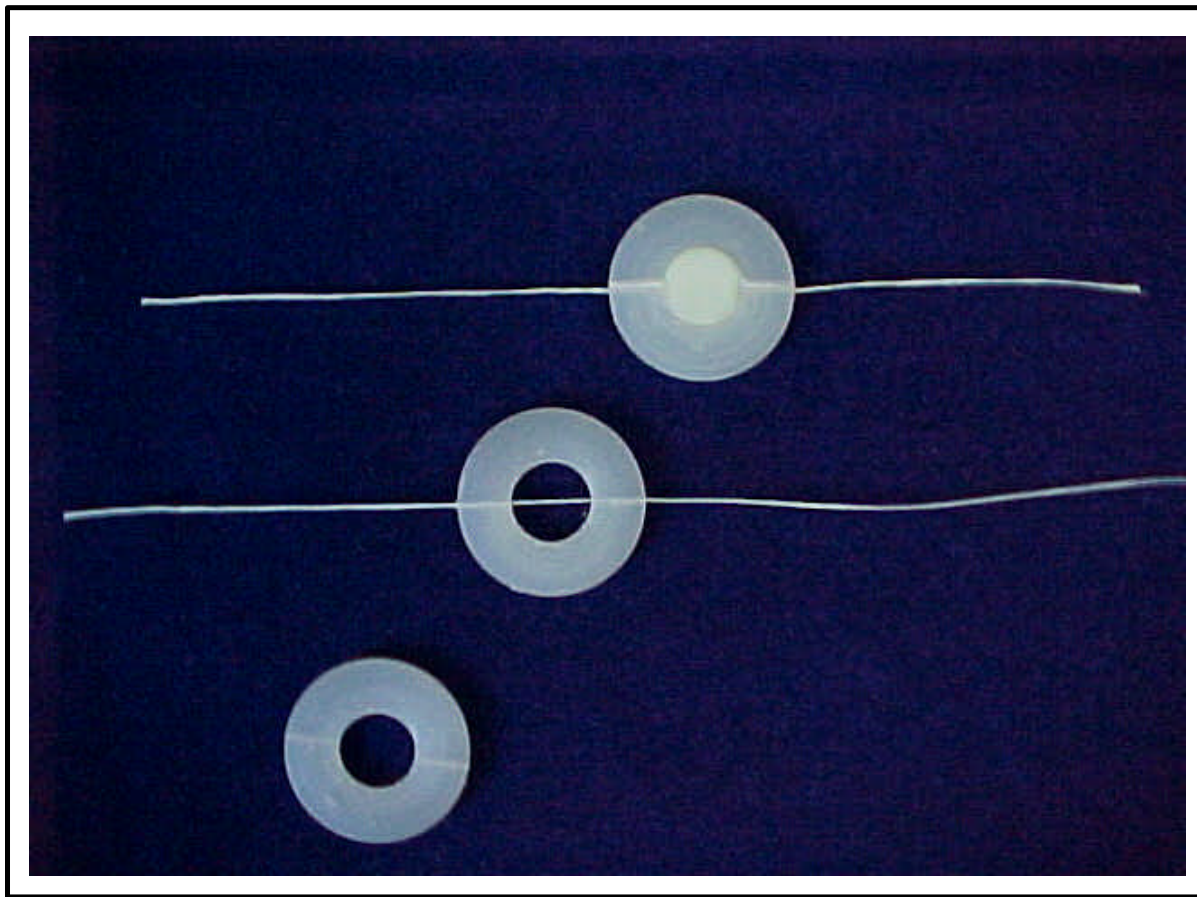

FIGURA 4.2 - Seqüência da preparação dos corpos-de-prova na matriz de Teflon 
Sobre uma placa de vidro foi colocada uma tira de poliéster e sobre esta, a matriz de Teflon, preparada com o fio dental transpondo o orifício central da porção interior da matriz, para posterior manuseio do corpo de prova. Os materiais restauradores foram manipulados seguindo as recomendações dos fabricantes (Tabela 4.3), em ambiente laboratorial onde a temperatura era mantida a $23 \pm 1^{0} \mathrm{C}$ e a umidade relativa em $50 \pm 5 \%$, o que era conseguido através de um aparelho condicionador de ar e um desumidificador, seguindo-se a especificação $n^{0} 7489$ da ISO.

TABELA 4.3 - Características da manipulação dos materiais restauradores, de acordo com os fabricantes

\begin{tabular}{cccc}
\hline \hline MATERIAL & $\begin{array}{c}\text { PROPORRÇÃO P/L } \\
\text { (peso em g) }\end{array}$ & $\begin{array}{c}\text { TEMPO DE } \\
\text { ESPATULAÇÃO }\end{array}$ & $\begin{array}{c}\text { TEMPO DE ATIVAÇÃO } \\
\text { PELA LUZ }\end{array}$ \\
\hline \hline Z 100 & - & - & $40 \mathrm{~s}$ \\
Vitremer $^{\mathrm{TM}}$ & $0,39 / 0,15$ & $45 \mathrm{~s}$ & $40 \mathrm{~s}$ \\
Dyract AP & - & - & $40 \mathrm{~s}$ \\
Tetric $^{\circledR}$ Ceram & - & - & $40 \mathrm{~s}$ \\
Ariston pHc & - & - & $40 \mathrm{~s}$ \\
Definite & - & - & $40 \mathrm{~s}$ \\
\hline \hline
\end{tabular}

Em virtude da importância do teor de flúor, as quantidades do pó/líquido do Vitremer foram medidas em balança (Sauter K 1200) com precisão de 0,01 g, respeitando-se a proporção volumétrica pó/líquido, determinada pelo fabricante (3 conchas $=0,39 \mathrm{~g}$ de pó; 3 gotas $=0,15 \mathrm{~g}$ de líquido) . 
O material restaurador foi inserido no orifício central da matriz com auxílio de uma seringa modelo Centrix até o seu preenchimento total, deixando um pequeno excesso. O material foi então coberto com uma tira de poliéster e comprimido, por meio de pressão digital, com uma lâmina de vidro (utilizada em microscopia) sobre a matriz, para eliminar o excesso do material, delimitar a espessura do corpo-de-prova e deixar sua superfície plana e lisa (Figura 4.3). Em seguida o material foi fotoativado durante 40 segundos por uma unidade para polimerização com luz visível (Optilux, Demetron, USA), aferida na potência de 500 $\mathrm{mW} / \mathrm{cm}$, por meio de um radiômetro (Demetron modelo 100, USA). Concluída a polimerização, e após um repouso de 10 minutos, os corpos-de-prova foram removidos manualmente e, então, imersos nas soluções anteriormente especificadas.

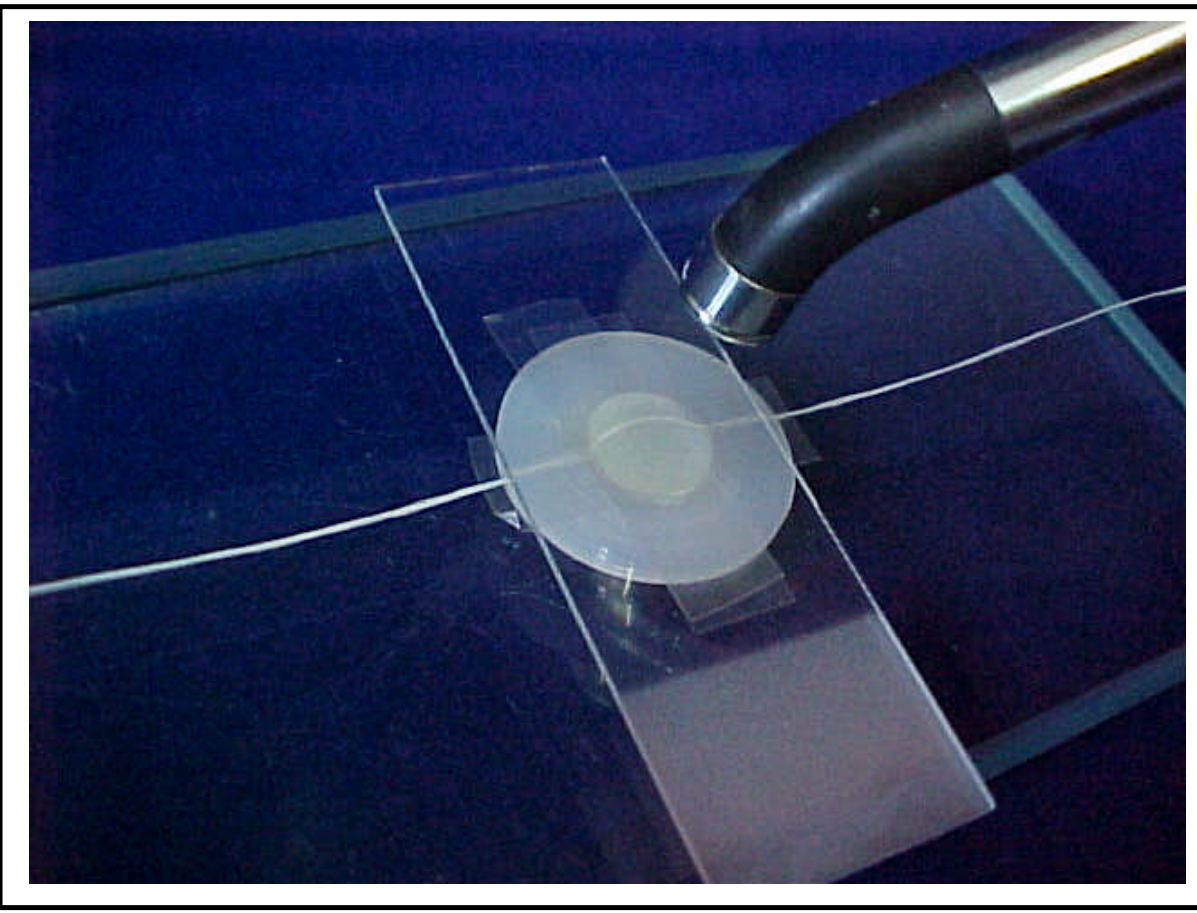

FIGURA 4.3 - Posicionamento da matriz para polimerização do material restaurador 


\subsubsection{Preparação dos recipientes para armazenamento e imersão dos corpos- de-prova}

Foram utilizados frascos plásticos de poliestireno, de 3,4 X 2,0 cm, com tampa de polietileno flexível. Cada tampa recebeu uma perfuração central para permitir a passagem do fio dental, sendo esse fixado à tampa pela sua parte externa, mantendo o corpo de prova em suspensão e, evitando ao mesmo tempo qualquer evaporação das soluções para o teste (Figura 4.4). A fixação do fio dental à tampa dos recipientes foi feita de duas formas, dependendo do meio de armazenamento. Foi utilizada a resina acrílica quimicamente ativada (Duralay) para os frascos com solução de ciclagem de $\mathrm{pH}$ e para os com água deionizada, a fixação foi feita com cola quente transparente.

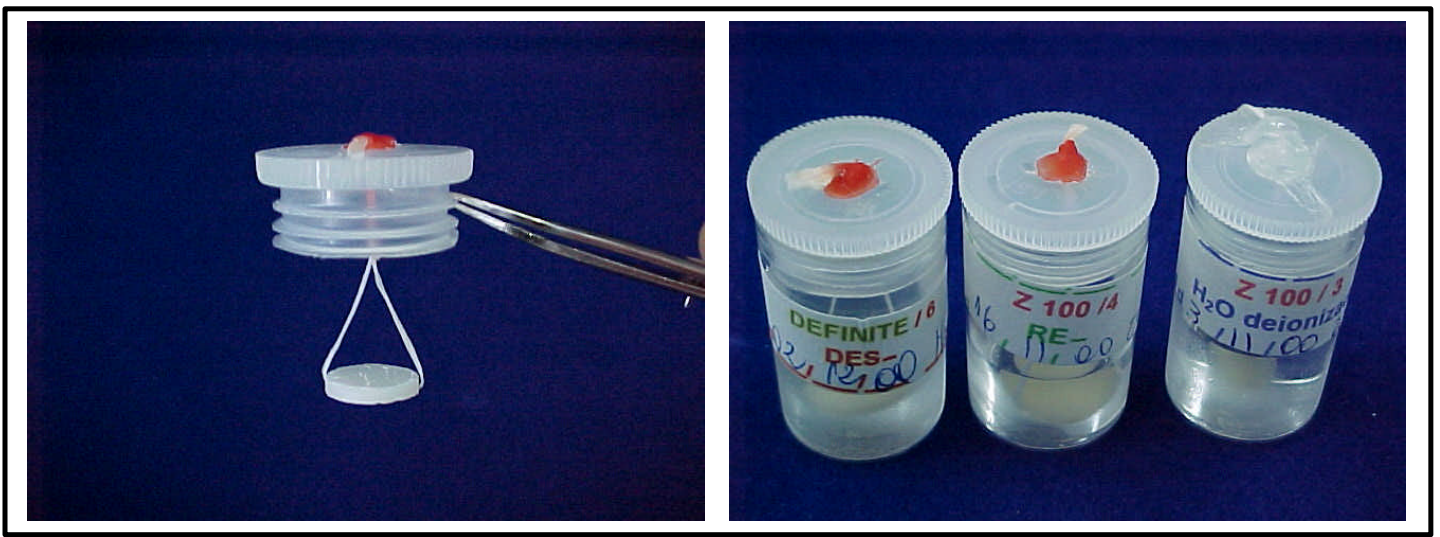

FIGURA 4.4 - Fixação do corpo de prova na tampa e em imersão no recipiente identificado

Os corpos-de-prova de cada material, individualmente fixados nas respectivas tampas, foram imersos em $4 \mathrm{~mL}$ de cada uma das soluções de tratamento, tomando-se cuidado para que não tocassem nas paredes do recipiente. Em seguida, foram levados para a mesa agitadora orbital Nova Técnica, modelo NT 145 , à temperatura média de $24^{0} \mathrm{C} \pm 1^{0} \mathrm{C}$, por um período de 15 dias (Figura 4.5). 
Durante esse período, as tampas dos recipientes com os espécimes eram transferidas para um novo frasco com igual quantidade da solução ${ }^{*}$, nos intervalos pré-determinados. Quando em água deionizada a cada 24 horas e, em ciclagem de $\mathrm{pH}$, permaneciam 6 horas na solução Des- e 18 na solução Re-, a fim de completarem o ciclo de 24 horas De acordo com Featherstone et al. ${ }^{26}$, esta avaliação in vitro por 15 dias, simula uma situação de alto risco de cárie, in vivo. Diariamente, os frascos contendo as soluções eram devidamente lacrados e identificados com o nome do material, o número do corpo de prova, data e horário da imersão nas soluções e, conservados em geladeira a $4^{0} \mathrm{C}$, até a leitura.

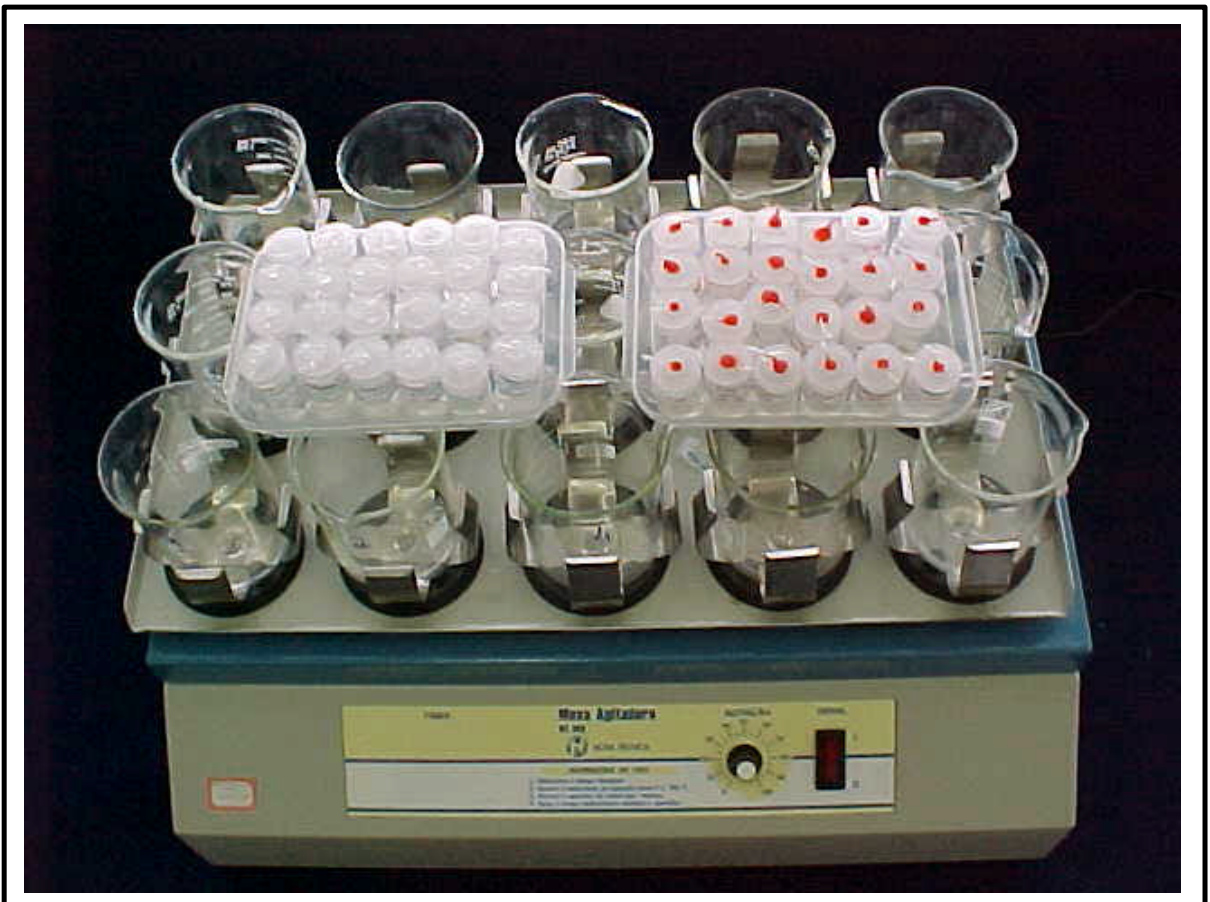

FIGURA 4.5 - Mesa agitadora Nova Técnica, modelo NT 145, com os corposde-prova

\footnotetext{
* Telma Lopes da Silva, Técnica do laboratório do Departamento de Ciências Biológicas (Bioquímica). Técnica responsável pelo preparo das soluções utilizadas.
} 


\subsubsection{Determinação da concentração de flúor}

Duas metodologias foram utilizadas para a determinação da concentração de flúor. Em água deionizada, a leitura foi feita pelo método direto e pela técnica de difusão facilitada por HMDS ${ }^{52,61}$. Esta última foi realizada para as resinas compostas DEF, TET e para o controle negativo $Z 100$, considerando os intervalos de tempo de 1, 7 e 15 dias, por apresentarem baixa concentração de flúor ao serem submetidas ao método direto.

\subsubsection{Análise da concentração de flúor pelo método direto}

A quantidade de flúor nas soluções foi medida usando um eletrodo $\mathrm{F}^{-}$ sensível (Orion, modelo 96-09) acoplado a um aparelho analisador digital de $\mathrm{pH} / \mathrm{F}^{-}$ (Procyon SA-720), previamente calibrados com uma série de soluções-padrão com as seguintes concentrações de $\mathrm{F}^{-}: 0,025,0,05,0,1,0,2,0,4,0,8,1,6,3,2 \mu \mathrm{g} \mathrm{F}-/ \mathrm{mL}$, após tamponamento com igual volume de TISAB II para as amostras de água deionizada. Para as leituras das amostras em ciclagem de pH, a calibração foi feita com soluções-padrão com concentrações de $F^{-}$de: 0,1, 0,2, 0,4, 0,8, 1,6, 3,2 e 6,4 $\mu \mathrm{F}^{-} / \mathrm{mL}$.

Para análise do $\mathrm{F}^{-}$liberado em água deionizada, $0,5 \mathrm{~mL}$ da amostra era adicionado a igual volume de TISAB II (tampão acetato 1,0 M, pH 5,0 contendo $\mathrm{NaCl} 1,0 \mathrm{M}$ e $\operatorname{CDTA}^{*}$ 0,4\%). A leitura das soluções-padrão foi feita em triplicata e das amostras em duplicata. Os valores obtidos em $\mathrm{mV}$ foram digitados em uma planilha de cálculos (Microsoft Excel) contendo os dados dos padrões com 
concentrações conhecidas de $\mathrm{F}^{-}$obtendo-se, a quantidade de flúor liberada, em $\mu \mathrm{g}$. Os resultados da quantidade de $\mathrm{F}^{-}$foram divididos pela área dos espécimes, obtendo-se então a liberação de flúor em $\mu \mathrm{g} \mathrm{F}^{-} / \mathrm{mm}^{2}$, sendo então tiradas as médias das leituras. A liberação de flúor diária de cada material, obtida de cada um dos corpos-de-prova, foi medida em duplicata, obtendo-se a média de cada corpode-prova por materia e por dia. Sendo assim foram feitas 240 leituras por material para cada meio de imersão. Os dados foram tabulados e submetidos a análise estatística.

$\mathrm{Na}$ análise da liberação no sistema de ciclagem de $\mathrm{pH}$, os dados encontrados nas soluções de desmineralização e remineralização foram somados, para que os resultados obtidos fossem correspondentes às dosagens de liberação de ciclos de 24 horas.

\section{Validação da análise:}

Para a validação da análise, as soluções-padrão empregadas na realização da curva de calibração foram preparadas por diluição seriada de um estoque-padrão contendo $100 \mathrm{ppm} \mathrm{F}^{-}$(Orion). As leituras obtidas em $\mathrm{mV}$, foram convertidas para $\mu \mathrm{g}$ de $\mathrm{F}^{-}$, através do Programa Excel (Microsoft). A média das leituras obtidas a partir dos padrões foi inserida na planilha, e então foi calculada a porcentagem de variação entre a quantidade de $\mathrm{F}^{-}$medida e a esperada pelos padrões. Somente curvas de calibração com porcentagem de variação de até $10 \%$ para todos os padrões foram aceitas. Em períodos de 2 em 2 horas, uma nova leitura da solução padrão de 0,4 ppm $\mathrm{F}^{-}$era feita para confirmar a curva de calibração. 


\subsubsection{Análise da concentração de íon após difusão facilitada por HMDS}

\section{Preparação das soluções testes}

A quantidade de $\mathrm{F}^{-}$presente foi analisada depois de difusão facilitada por HMDS ${ }^{61}$, usando-se o mesmo eletrodo e o potenciômetro anteriormente citados. Para tanto, $0,5 \mathrm{~mL}$ de cada amostra, $2,5 \mathrm{~mL}$ de água deionizada foram colocados em placas de Petri plásticas (Falcon, $n^{\circ} 1007$ ). No centro desta placa foi fixada com vaselina uma tampa de polietileno (Falcon, $\mathrm{n}^{\circ 2030}$ ), na qual foi colocado $0,1 \mathrm{~mL}$ de $\mathrm{NaOH} 1,65 \mathrm{~N}$ ). A placa foi então fechada e sua tampa vedada com vaselina sólida. Por um orifício, feito previamente na tampa, foi colocado 1,0 mL de HMDS em HCL $6 \mathrm{~N}$, sendo o orifício imediatamente vedado com vaselina. As placas foram colocadas em uma mesa agitadora orbital plana (Nova Técnica, modelo NT 145) em velocidade 4-5, durante 12 horas. Em seguida, as tampas de polietileno foram removidas, identificadas e colocadas em estufa a $60^{\circ} \mathrm{C}$ por 2 horas. A tampa de polietileno foi, então, encaixada no tubo de ensaio de poliestireno (Falcon, $n^{\circ 2017)}$ contendo $0,4 \mathrm{~mL}$ de ácido acético $0,66 \mathrm{~N}$, que foi invertido e agitado vigorosamente no agitador de tubos, para dissolver os cristais de $\mathrm{NaF}$, e em seguida foram realizadas as leituras. Os padrões de $\mathrm{F}^{-}$foram preparados em triplicata e difundidos da mesma maneira.

\section{Validação da análise:}

Para a validação da análise, as soluções-padrão empregadas na realização da curva de calibração foram preparadas por diluição seriada de um estoque-padrão contendo 100 ppm $\mathrm{F}^{-}$(Orion) e difundidas em triplicata, em concomitância com as amostras dos materiais a serem analisados. 
As leituras obtidas em $\mathrm{mV}$, foram convertidas para $\mu \mathrm{g}$ de $\mathrm{F}^{-}$, através do Programa Excel (Microsoft). A média das leituras obtidas a partir dos padrões foi inserida na planilha, e então foi calculada a porcentagem de variação entre a quantidade de $\mathrm{F}^{-}$medida e a esperada pelos padrões. Somente curvas de calibração com porcentagem de variação de até $10 \%$ para todos os padrões foram aceitas.

\subsubsection{Análise estatística}

Os critérios utilizados para a análise estatística foram os materiais restauradores (A, VIT, DYR, DEF, TET e Z 100), os meios de imersão $\left(\mathrm{H}_{2} \mathrm{O}\right.$ e $\left.\mathrm{CpH}\right)$ e, o tempo de 1 a 15 dias. A variável avaliada foi a quantidade de flúor liberada por área, $\mu \mathrm{g} \mathrm{F}^{-} / \mathrm{mm}^{2}$.

Os resultados foram submetidos a análise de variância (ANOVA). Para as comparações individuais entre os tratamentos foi usado o teste de Tukey $(p<0,05)$. 
5 RESULTADOS 


\section{RESULTADOS}

Os valores médios de liberação diária dos corpos de prova estão demostrados nos Anexos 1 a 18, distribuídos de acordo com o meio de imersão.

As médias e desvios padrão das taxas de liberação de flúor dos materiais, no período de 24 horas, foram tabulados de acordo com os meios de imersão, água deionizada(Tabela 5.1) e $\mathrm{CpH}$ (Tabela 5.2), durante os 15 dias de experimento.

A distribuição das médias e desvios padrão no $1^{\circ}$, $7^{\circ}$ e $15^{\circ}$ dias estão na Tabela 5.3. 
TABELA 5.1 - Média da quantidade de liberação de $\mathrm{F}$ em $\mu \mathrm{g} / \mathrm{mm}^{2}$ e desvio padrão dos materiais restauradores em $\mathrm{H}_{2} 0$, durante15 dias, e os totais acumulados nas $1^{\underline{a}}$ e $2^{\underline{a}}$ semanas.

\begin{tabular}{|c|c|c|c|c|c|c|c|c|c|c|c|c|}
\hline \multirow[b]{2}{*}{ dias } & \multicolumn{2}{|c|}{ A } & \multicolumn{2}{|c|}{ VIT } & \multicolumn{2}{|c|}{ DYR } & \multicolumn{2}{|c|}{ DEF } & \multicolumn{2}{|c|}{ TET } & \multicolumn{2}{|c|}{$Z 100$} \\
\hline & média & dp & média & $d p$ & média & $d p$ & média & $d p$ & média & $d p$ & média & $d p$ \\
\hline 1 & 0.3000 & 0.1170 & 0.6868 & 0.1384 & 0.0616 & 0.0181 & 0.0011 & 0.0001 & 0.0071 & 0.0031 & 0.0010 & 0.0003 \\
\hline 2 & 0,2688 & 0,2885 & 0,2422 & 0,0345 & 0,0336 & 0,0071 & 0,0006 & 0,0002 & 0,0014 & 0,0006 & & \\
\hline 3 & 0,1614 & 0,0332 & 0,1508 & 0,0159 & 0,0229 & 0,0066 & 0,0005 & 0,0002 & 0,0006 & 0,0002 & & \\
\hline 4 & 0,2156 & 0,0464 & 0,1169 & 0,0184 & 0,0211 & 0,0071 & 0,0006 & 0,0001 & 0,0004 & 0,0001 & & \\
\hline 5 & 0,2689 & 0,0634 & 0,1043 & 0,0162 & 0,0179 & 0,0064 & 0,0005 & 0,0002 & 0,0005 & 0,0001 & & \\
\hline 6 & 0,2558 & 0,0608 & 0,0740 & 0,0114 & 0,0137 & 0,0040 & 0,0007 & 0,0004 & 0,0004 & 0,0001 & & \\
\hline 7 & 0,2306 & 0,0584 & 0,0531 & 0,0137 & 0,0097 & 0,0044 & 0,0006 & 0,0001 & 0,0005 & 0,0002 & 0,0005 & 0,0001 \\
\hline 8 & 0,2359 & 0,0556 & 0,0460 & 0,0118 & 0,0123 & 0,0030 & 0,0011 & 0,0011 & 0,0004 & 0,0001 & & \\
\hline 9 & 0,2331 & 0,0254 & 0,0453 & 0,0069 & 0,0092 & 0,0023 & 0,0006 & 0,0007 & 0,0003 & 0,0001 & & \\
\hline 10 & 0,2512 & 0,0592 & 0,0439 & 0,0086 & 0,0085 & 0,0020 & 0,0003 & 0,0001 & 0,0003 & 0,0002 & & \\
\hline 11 & 0,2512 & 0,0442 & 0,0418 & 0,0068 & 0,0081 & 0,0018 & 0,0003 & 0,0001 & 0,0004 & 0,0001 & & \\
\hline 12 & 0,2490 & 0,0336 & 0,0383 & 0,0060 & 0,0075 & 0,0013 & 0,0004 & 0,0003 & 0,0004 & 0,0002 & & \\
\hline 13 & 0,2384 & 0,0350 & 0,0356 & 0,0065 & 0,0073 & 0,0012 & 0,0002 & 0,0001 & 0,0004 & 0,0002 & & \\
\hline 14 & 0,2574 & 0,0365 & 0,0368 & 0,0056 & 0,0077 & 0,0011 & 0,0008 & 0,0010 & 0,0004 & 0,0003 & & \\
\hline 15 & 0,2430 & 0,0339 & 0,0371 & 0,0057 & 0,0070 & 0,0011 & 0,0003 & 0,0002 & 0,0005 & 0,0004 & 0,0005 & 0,0004 \\
\hline $1^{\text {a }}$ sem & 1.7010 & & 1.4281 & & 0.1805 & & 0.0046 & & 0.0109 & & 0.0015 & \\
\hline $2^{a}$ sem & 1,7162 & & 0,02877 & & 0,0606 & & 0,0037 & & 0,0026 & & & \\
\hline $1^{\mathrm{a}}+2^{\mathrm{a}} \mathrm{s}$ & 3,4173 & & 1,7158 & & 0,2411 & & 0,0083 & & 0,0135 & & & \\
\hline
\end{tabular}


TABELA 5.2 - Média da quantidade de liberação de $\mathrm{F}$ em $\mu \mathrm{g} / \mathrm{mm}^{2}$ e desvio padrão dos materiais restauradores em $\mathrm{CpH}$, durante 15 dias, e os totais acumulados nas $1^{\mathrm{a}}$ e $2^{\mathrm{a}}$ semanas.

\begin{tabular}{|c|c|c|c|c|c|c|c|c|c|c|c|c|}
\hline \multirow[b]{2}{*}{ dias } & \multicolumn{2}{|c|}{ A } & \multicolumn{2}{|c|}{ VIT } & \multicolumn{2}{|c|}{ DYR } & \multicolumn{2}{|c|}{ DEF } & \multicolumn{2}{|c|}{ TET } & \multicolumn{2}{|c|}{ Z 100} \\
\hline & média & $d p$ & média & $d p$ & média & $d p$ & média & $d p$ & média & $d p$ & média & $d p$ \\
\hline 1 & 0.2972 & 0.0705 & 1.3212 & 0.3330 & 0.2384 & 0.0254 & 0.0045 & 0.0007 & 0.0276 & 0.0216 & 0.0043 & 0.0258 \\
\hline 2 & 0,2180 & 0,0454 & 0,4748 & 0,0909 & 0,0760 & 0,0088 & 0,0006 & 0,0002 & 0,0014 & 0,0006 & & \\
\hline 3 & 0,2183 & 0,0375 & 0,3230 & 0,0775 & 0,0609 & 0,0079 & & & & & & \\
\hline 4 & 0,1812 & 0,0385 & 0,2366 & 0,0541 & 0,0545 & 0,0066 & & & & & & \\
\hline 5 & 0,1285 & 0,0344 & 0,1427 & 0,0356 & 0,0555 & 0,0039 & & & & & & \\
\hline 6 & 0,1596 & 0,0165 & 0,1251 & 0,0374 & 0,0770 & 0,0078 & & & & & & \\
\hline 7 & 0,1481 & 0,0131 & 0,1364 & 0,0291 & 0,0732 & 0,0056 & 0,0007 & 0,0002 & 0,0010 & 0,0002 & 0,0011 & 0,0002 \\
\hline 8 & 0,1309 & 0,0092 & 0,1083 & 0,0237 & 0,0671 & 0,0030 & & & & & & \\
\hline 9 & 0,1278 & 0,0096 & 0,1055 & 0,0208 & 0,0682 & 0,0038 & & & & & & \\
\hline 10 & 0,0901 & 0,0245 & 0,0885 & 0,0238 & 0,0555 & 0,0029 & & & & & & \\
\hline 11 & 0,0911 & 0,0171 & 0,0682 & 0,0121 & 0,0529 & 0,0023 & & & & & & \\
\hline 12 & 0,0939 & 0,0110 & 0,0595 & 0,0135 & 0,0648 & 0,0503 & & & & & & \\
\hline 13 & 0,0917 & 0,0075 & 0,0845 & 0,0155 & 0,0466 & 0,0028 & & & & & & \\
\hline 14 & 0,0853 & 0,0098 & 0,0788 & 0,0173 & 0,0420 & 0,0038 & & & & & & \\
\hline 15 & 0,0805 & 0,0139 & 0,0835 & 0,0146 & 0,0429 & 0,0035 & 0,0011 & 0,0002 & 0,0011 & 0,0001 & 0,0013 & 0,0001 \\
\hline $1^{a}$ sem & 1.3509 & & 2.7598 & & 0.6346 & & 0.0052 & & 0.0286 & & 0.0054 & \\
\hline $2^{a}$ sem & 0,7108 & & 0,5933 & & 0,3916 & & & & & & & \\
\hline $1^{a}+2^{a} s$ & 2,0617 & & 3,3531 & & 1,0262 & & & & & & & \\
\hline
\end{tabular}


TABELA 5.3 - Média da quantidade de liberação de $\mathrm{F}$ em $\mu \mathrm{g} / \mathrm{mm}^{2}$, e o desvio padrão dos materiais restauradores, em $\mathrm{H}_{2} \mathrm{O}$ e em $\mathrm{CpH}$ nos períodos de $1^{\circ}$, $7^{\circ}$ e e $15^{\circ}$ dias

\begin{tabular}{|c|c|c|c|c|c|c|c|}
\hline \multirow{2}{*}{ Meio } & \multirow{2}{*}{ material } & \multicolumn{2}{|c|}{$\begin{array}{ll}1^{\circ} & \text { dia } \\
\end{array}$} & \multicolumn{2}{|c|}{$7^{\circ} \quad$ dias } & \multicolumn{2}{|c|}{$15^{\circ}$} \\
\hline & & média & $d p$ & Média & $d p$ & Média & $d p$ \\
\hline $\mathrm{H} 2 \mathrm{O}$ & A & 0,3000 & 0,1170 & 0,2306 & 0,0584 & 0,2430 & 0,0339 \\
\hline $\mathrm{H} 2 \mathrm{O}$ & VIT & 0,6868 & 0,1384 & 0,0531 & 0,0137 & 0,0371 & 0,0057 \\
\hline $\mathrm{H} 2 \mathrm{O}$ & DYR & 0,0616 & 0,0181 & 0,0097 & 0,0044 & 0,0070 & 0,0011 \\
\hline $\mathrm{H} 2 \mathrm{O}$ & DEF & 0,0011 & 0,0001 & 0,0006 & 0,0001 & 0,0003 & 0,0002 \\
\hline $\mathrm{H} 2 \mathrm{O}$ & TET & 0,0071 & 0,0031 & 0,0005 & 0,0002 & 0,0005 & 0,0004 \\
\hline $\mathrm{H} 2 \mathrm{O}$ & Z 100 & 0,0010 & 0,0003 & 0,0005 & 0,0001 & 0,0005 & 0,0001 \\
\hline $\mathrm{CPH}$ & A & 0,2972 & 0,0705 & 0,1481 & 0,0131 & 0,0805 & 0,0139 \\
\hline $\mathrm{CPH}$ & VIT & 1,3212 & 0,3330 & 0,1364 & 0,0291 & 0,0835 & 0,0146 \\
\hline $\mathrm{CPH}$ & DYR & 0,2384 & 0,0254 & 0,0732 & 0,0056 & 0,0429 & 0,0035 \\
\hline $\mathrm{CPH}$ & DEF & 0,0045 & 0,0007 & 0,0007 & 0,0002 & 0,0011 & 0,0002 \\
\hline $\mathrm{CPH}$ & TET & 0,0276 & 0,0216 & 0,0010 & 0,0002 & 0,0011 & 0,0001 \\
\hline $\mathrm{CPH}$ & Z 101 & 0,0043 & 0,0258 & 0,0011 & 0,0002 & 0,0013 & 0,0001 \\
\hline
\end{tabular}

Em valores absolutos, observa-se que o VIT foi o material que mais liberou tanto na água deionizada quanto na $\mathrm{CpH}$, no $1^{\circ}$ dia. Ao $7^{\circ}$ dia e $15^{\circ}$ dia 0 Ariston $(A)$ alcançou melhores resultados.

No sistema de ciclagem de $\mathrm{pH}$ observa-se esta mesma variação.

A Tabela 5.4 refere-se ao teste de análise de variância (ANOVA) a 3 critérios. Os critérios considerados foram meio, material e tempo. De acordo com o resultado dessa análise, concluímos que houve interação entre os critérios, portanto são estatisticamente significantes $\left({ }^{*}\right)$ quando $p<0,05$. 
TABELA 5.4 - Análise de variância a 3 critérios, meio, material e tempo

\begin{tabular}{lcccccc}
\hline Efeito & gl efeito & QM efeito & gl erro & QM erro & F & p \\
\hline \hline Meio & 1 &, 150586 & 84 &, 005146 & 29,2629 &, $000001^{*}$ \\
\hline Material & 5 & 1,184493 & 84 &, 005146 & 230,1784 & $0,000000^{*}$ \\
\hline Tempo & 2 & 1,256031 & 168 &, 003946 & 318,3264 & $0,000000^{*}$ \\
\hline Meio/Material & 5 &, 162357 & 84 &, 005146 & 31,5503 &, $000000^{*}$ \\
\hline Meio/Tempo & 2 &, 160995 & 168 &, 003946 & 40,7921 &, $000000^{*}$ \\
\hline Material/Tempo & 10 &, 697097 & 168 &, 003946 & 176,6710 & $0,000000^{*}$ \\
\hline Meio/Material/Tempo & 10 &, 064271 & 168 &, 003946 & 16,2887 &, $000000^{*}$ \\
\hline \hline
\end{tabular}

* estatisticamente significante $(p<0,05)$

Da mesma forma, as Tabelas 5.5 a 5.7 mostram a análise de variância a dois critérios, meio e material, considerando os intervalos de tempo de $1^{\circ}, 7^{\circ}$ e $15^{\circ}$ dias.

TABELA 5.5 - Análise de variância a 2 critérios, considerando o $1^{\circ}$ dia

\begin{tabular}{lcccccc}
\hline \hline Efeito & gl efeito & QM efeito & gl erro & QM erro & F & p \\
\hline \hline Meio & 1 &, 465568 & 84 &, 012515 & 37,1998 &, $000000^{*}$ \\
\hline Material & 5 & 2,422842 & 84 &, 012515 & 193,5896 & $0,000000^{*}$ \\
\hline Meio/Material & 5 &, 254202 & 84 &, 012515 & 20,3112 &, $000000^{*}$ \\
\hline \hline
\end{tabular}

* estatisticamente significante $(p<0,05)$ 
TABELA 5.6 - Análise de variância a 2 critérios, considerando o $7^{\circ}$ dia

\begin{tabular}{lcccccc}
\hline \hline Efeito & gl efeito & QM efeito & gl erro & QM erro & F & p \\
\hline \hline Meio & 1 &, 002866 & 84 &, 000389 & 7,3732 &, $008035^{*}$ \\
\hline Material & 5 &, 091666 & 84 &, 000389 & 235,8561 & $0,000000^{*}$ \\
\hline Meio/Material & 5 &, 013648 & 84 &, 000389 & 35,1156 &, $000000^{*}$ \\
\hline \hline
\end{tabular}

* estatisticamente significante $(p<0,05)$

TABELA 5.7 - Análise de variância a 2 critérios, considerando o 15 dia

\begin{tabular}{lcccccc}
\hline \hline Efeito & gl efeito & QM efeito & gl erro & QM erro & F & p \\
\hline Meio & 1 &, 004061 & 84 &, 000133 & 30,4337 &, $000000^{*}$ \\
\hline Material & 5 &, 064178 & 84 &, 000133 & 480,9345 & $0,000000^{*}$ \\
\hline Meio/Material & 5 &, 023049 & 84 &, 000133 & 172,7231 &, $000000^{*}$ \\
\hline \hline
\end{tabular}

* estatisticamente significante $(p<0,05)$

As médias de liberação de flúor dos materiais em cada meio, foram analisadas pelo teste de Tukey para comparações múltiplas, nos $1^{\circ}, 7^{\circ}$ e $15^{\circ}$ dias.

As Figuras 5.1.a e 5.1.b representam o padrão de liberação de flúor, em água deionizada e as Figuras 5.2.a e 5.2.b, em solução de ciclagem de pH (DES / $\mathrm{RE})$, nos intervalos de tempo de 1 a 15 dias. O maior pico de liberação dos materiais, nos mesmos períodos, ocorreu no $1^{\circ}$ dia, declinando no $2^{\circ}$ dia. A partir do $7^{0}$ dia, os níveis de liberação foram baixos. O material Ariston apresentou um comportamento constante no processo de liberação. 


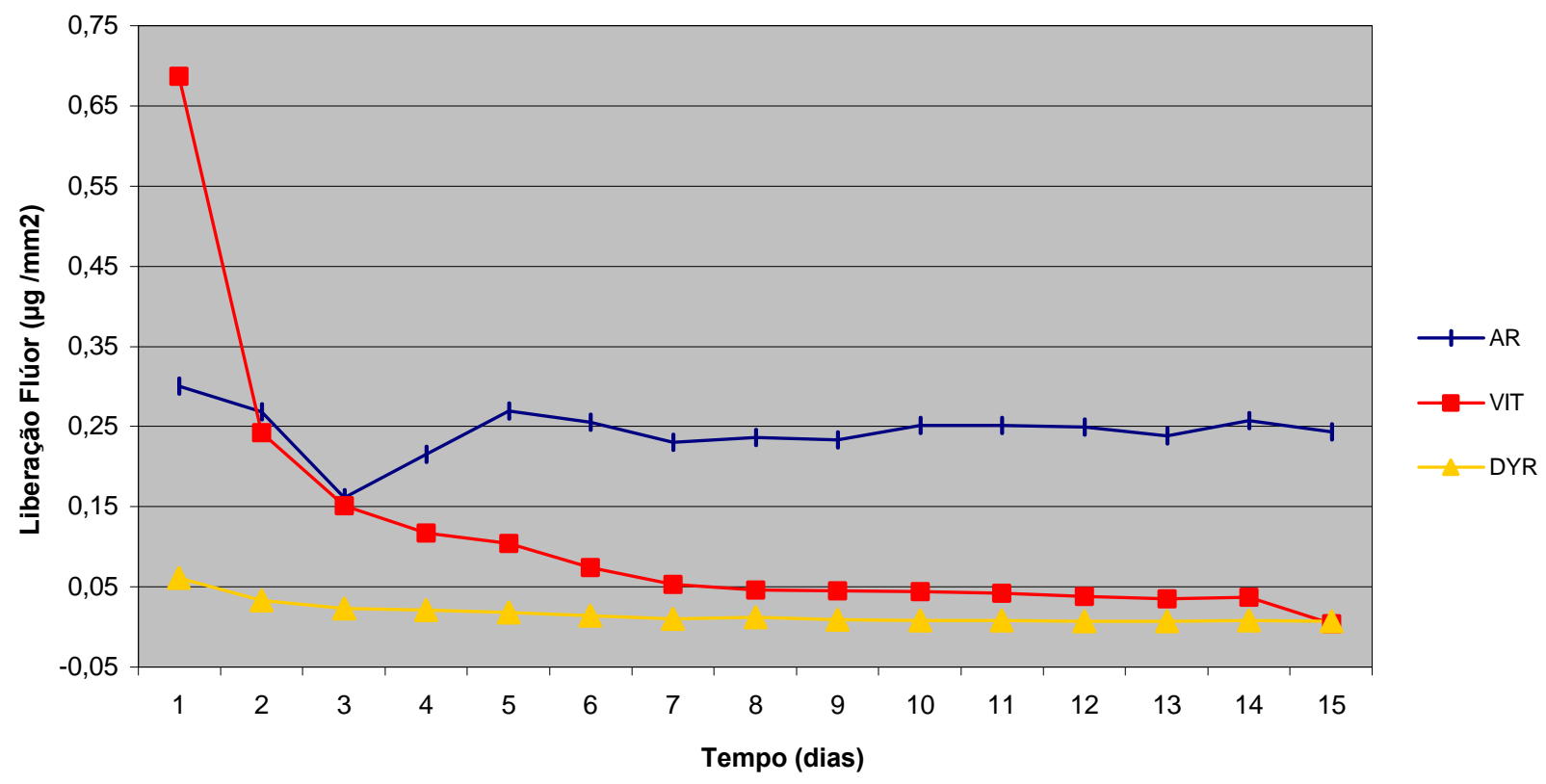

FIGURA 5.1.a - Gráfico da média da quantidade de liberação de $\mathrm{F}$ em $\mu \mathrm{g} / \mathrm{mm}^{2}$ dos materiais restauradores em $\mathrm{H}_{2} \mathrm{O}$, durante 15 dias

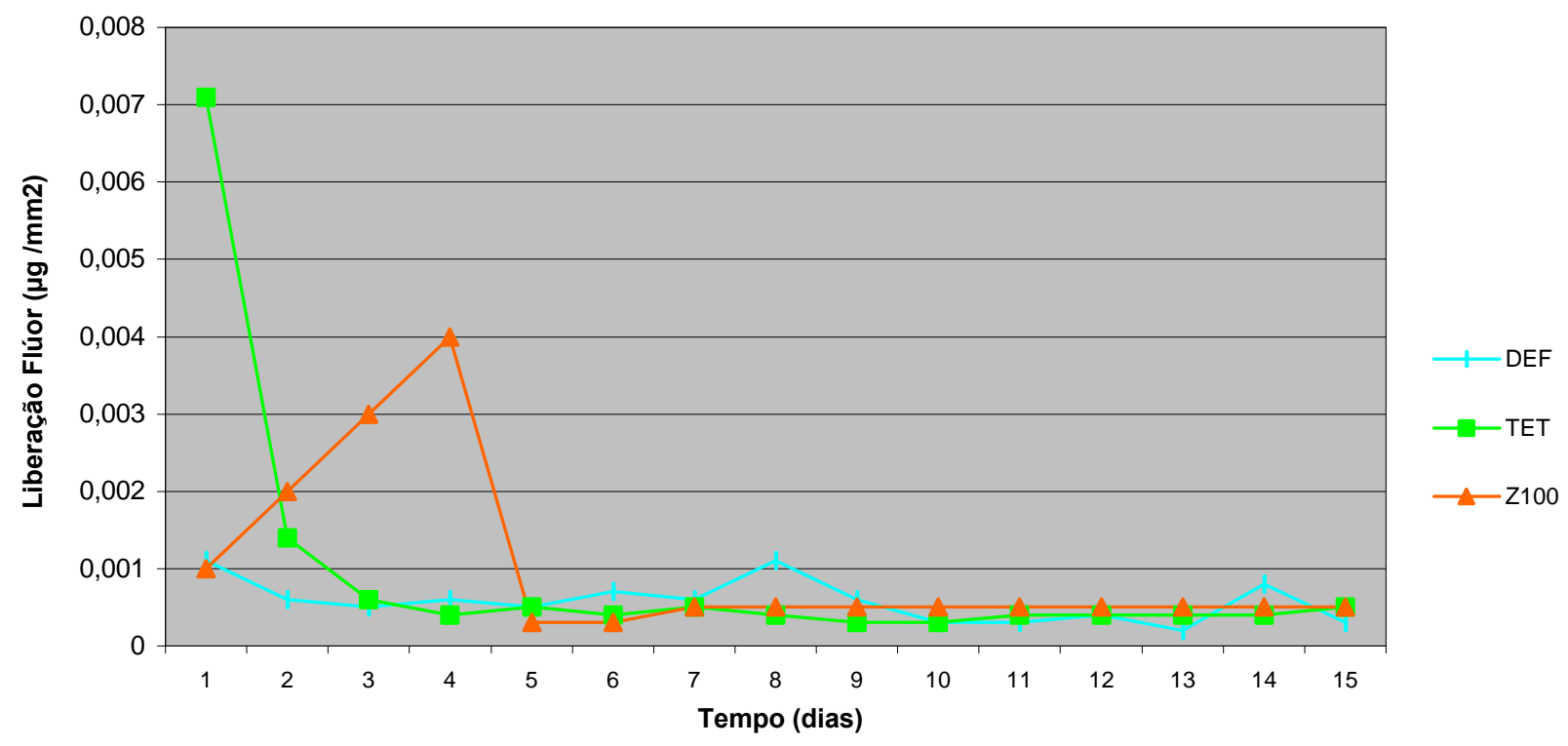

FIGURA 5.1.b - Gráfico da média da quantidade de liberação de $\mathrm{F}$ em $\mu \mathrm{g} / \mathrm{mm}^{2}$ dos materiais restauradores em $\mathrm{H}_{2} \mathrm{O}$, durante 15 dias 


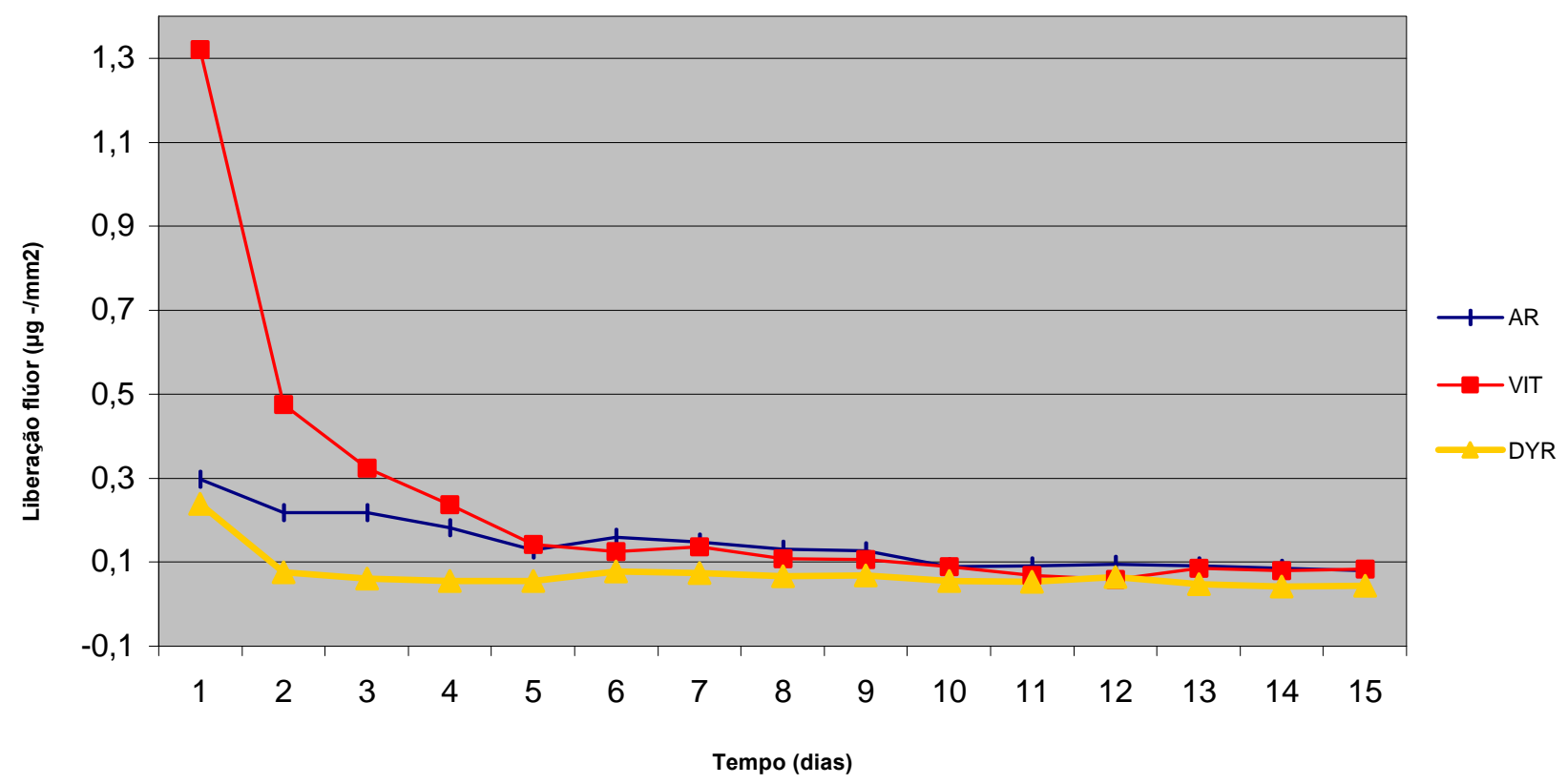

FIGURA 5.2.a - Gráfico da média da quantidade de liberação de $F$ em $\mu \mathrm{g} / \mathrm{mm}^{2}$ dos materiais restauradores em $\mathrm{CpH}$, durante 15 dias

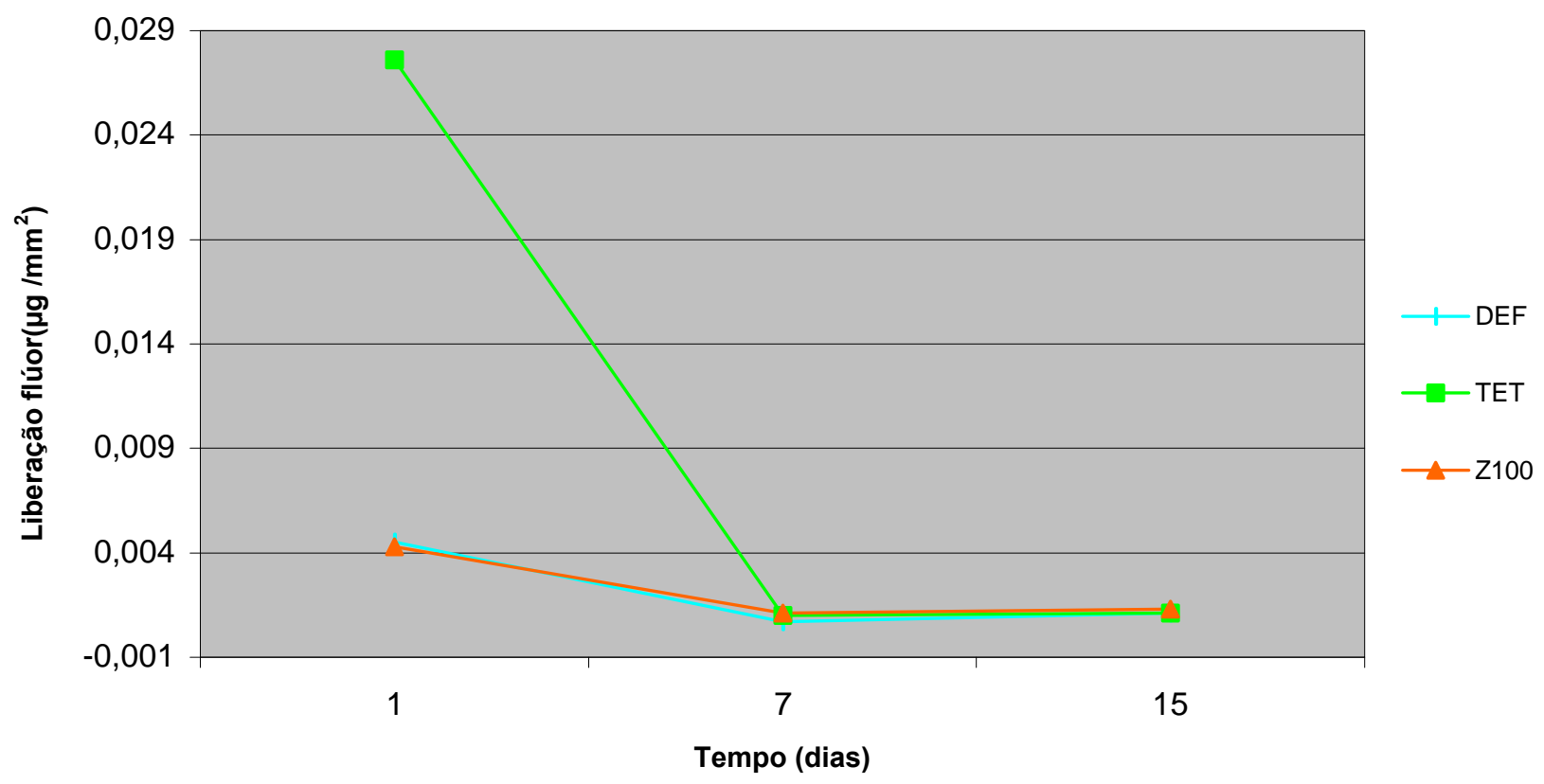

FIGURA 5.2.b - Gráfico da média da quantidade de liberação de $F$ em $\mu \mathrm{g} / \mathrm{mm}^{2}$ dos materiais restauradores em $\mathrm{CpH}$, nos $1^{\circ}, 7^{\circ}$ e e $15^{\circ}$ dias 
Os materiais que liberaram menores quantidades de $\mathrm{F}^{-}$, em ordem decrescente foram DYR $>$ DEF > TET, independente do meio de armazenamento. Na resina Z 100 foi detectada a liberação do íon (Tabela 5.3), mas estatisticamente não significante ( $p$ > 0,05) em relação ao DEF e TET. (Tabela 5.8 a 5.13).

Em meio de água deionizada, no 1ำ dia, a maior liberação de flúor foi observada no VIT $\left(0,6868 \mu \mathrm{g} \mathrm{F}-\mathrm{mm}^{2}\right)$, seguida pela resina composta Ariston $\left(0,3000 \mu \mathrm{g} \mathrm{F}^{-} / \mathrm{mm}^{2}\right)$, sendo essa diferença estatisticamente significante $(p<0,05)$ (Tabela 5.8). O Ariston apresentou um padrão de liberação estável a partir do 5ํ dia em $0,2689 \mu \mathrm{g} \mathrm{F}-/ \mathrm{mm}^{2}$, ao $7^{\circ}$ dia em $0,2306 \mu \mathrm{g} \mathrm{F}^{-} / \mathrm{mm}^{2}$ e ao $1^{\circ}$ dia em $0,2430 \mu \mathrm{g}$ $\mathrm{F}^{-} / \mathrm{mm}^{2}$. O material VIT apresentou a queda mais brusca entre $0^{\circ} 1^{\circ}(0,6868 \mu \mathrm{g}$ $\left.\mathrm{F}^{-} / \mathrm{mm}^{2}\right)$ e o $2^{\circ}$ dia $\left(0,2422 \mu \mathrm{g} \mathrm{F}^{-} / \mathrm{mm}^{2}\right)$. A partir do $7^{\circ}$ dia, em ordem decrescente, os materiais DYR, DEF e TET registraram os valores mais baixos, mas não houve diferença estatisticamente significante $(p<0,05)$, conforme a Tabela 5.9 .

A Figura 5.3 representa o Ariston pHc, variando de 0,3000, 0,2306 e $0,2430 \mu \mathrm{g} \mathrm{F}^{-} / \mathrm{mm}^{2}$ em água deionizada. Esses valores correspondem aos intervalos de tempo do $1^{\circ}, 7^{\circ}$ e $15^{\circ}$ dias, respectivamente. 


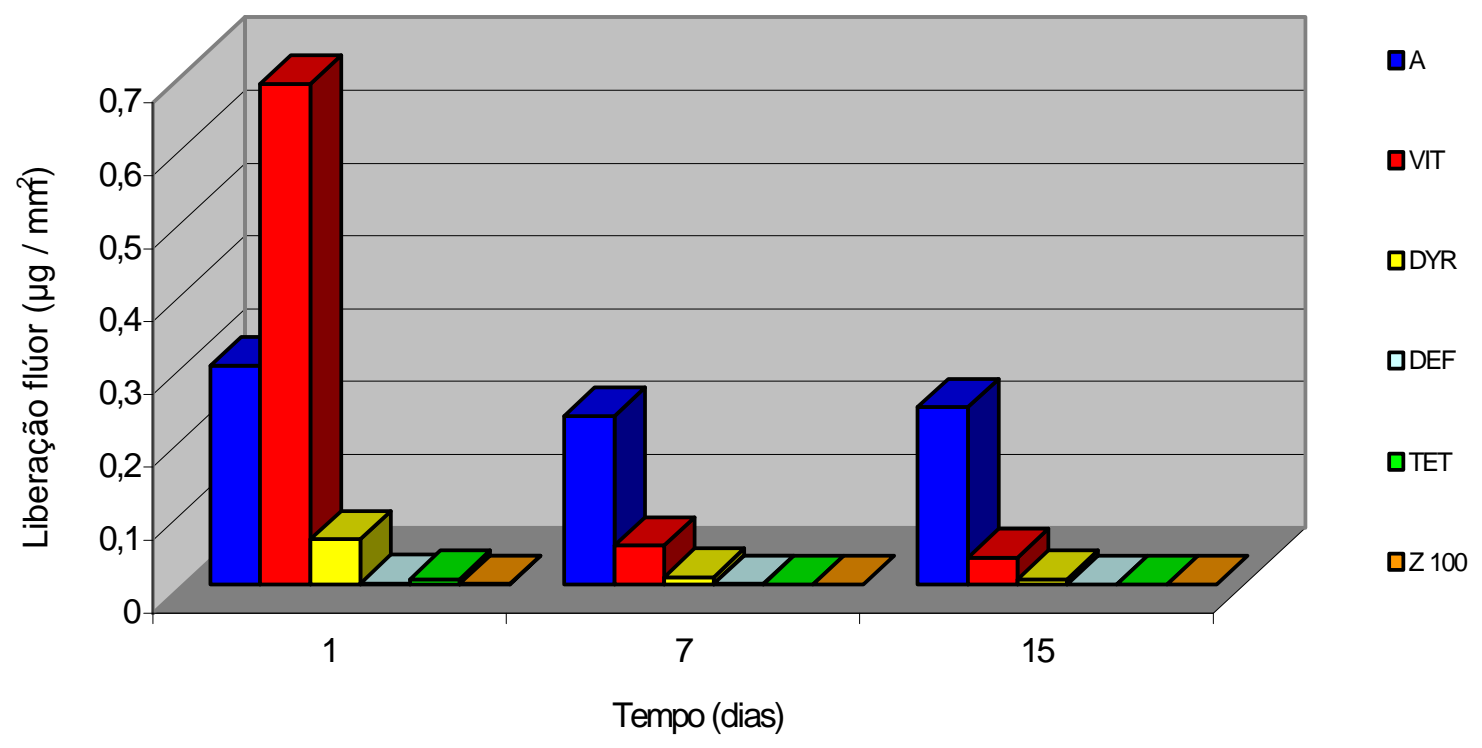

FIGURA 5.3 - Gráfico da média da quantidade de liberação de $\mathrm{F}$ em $\mu \mathrm{g} / \mathrm{mm}^{2}$ dos materiais restauradores, em $\mathrm{H}_{2} \mathrm{O}$, em 24 horas, nos períodos de 1, 7 e 15 dias

A Figura 5.4 reproduz a distribuição total de liberação de flúor no período considerado.

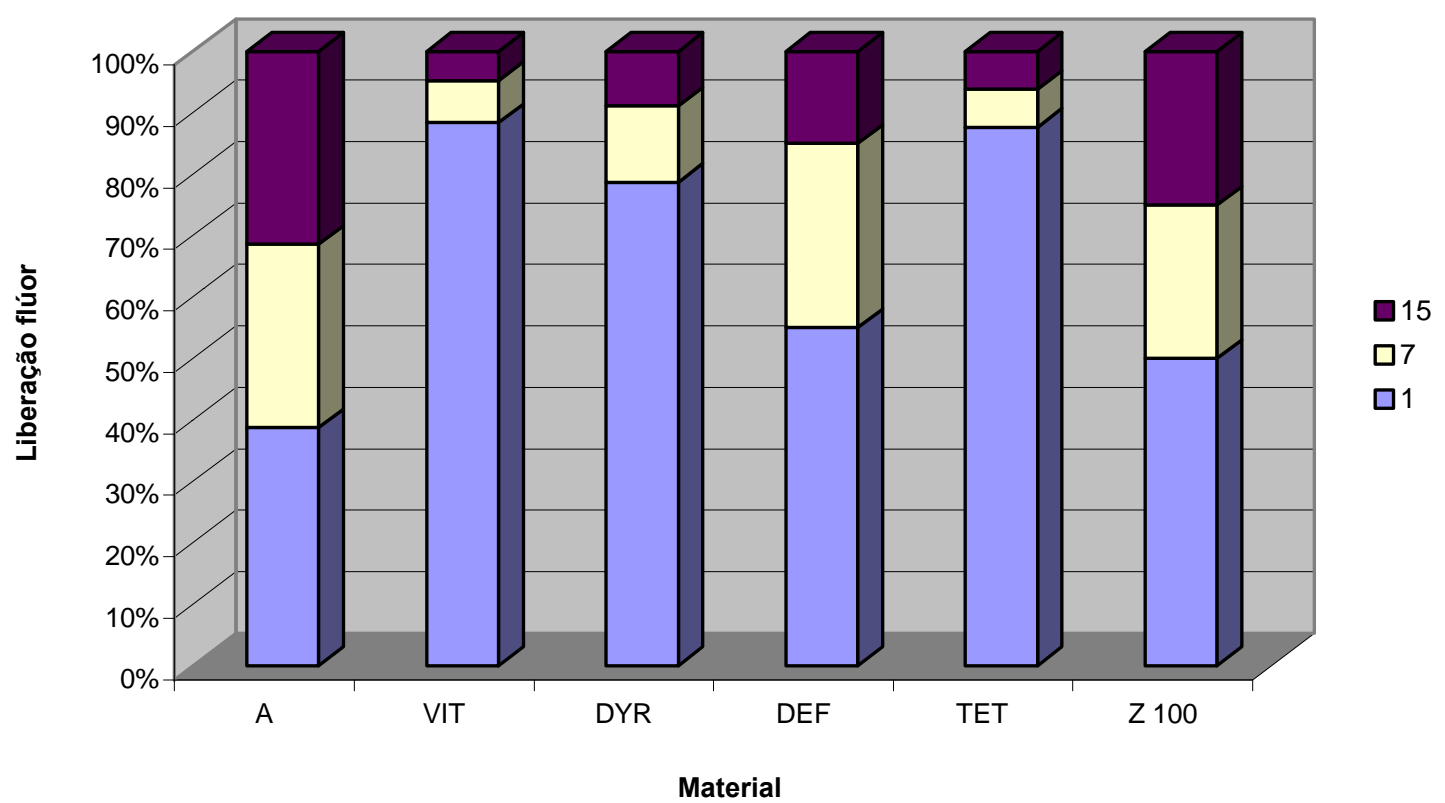

FIGURA 5.4 - Gráfico da distribuição total de liberação de flúor nos 1ำ $7^{\circ}$ e $15^{\circ}$ dias 
A Figura 5.5 descreve a $\mathrm{CpH}$. A. maior taxa de liberação foi observada no $1^{\circ}$ dia, destacando-se a do VIT $\left(1,3212 \mu \mathrm{g} \mathrm{F}^{-} / \mathrm{mm}^{2}\right)$, seguido do Ariston $(0,2972 \mu \mathrm{g}$ $\mathrm{F}^{-} / \mathrm{mm}^{2}$ ). A partir do $7^{\circ}$ dia o Ariston manteve uma liberação constante, com declínio lento, de $0,1481 \mu \mathrm{g} \mathrm{F}^{-} / \mathrm{mm}^{2}$ para $0,0805 \mu \mathrm{g} \mathrm{F}^{-} / \mathrm{mm}^{2}$ no $15^{\circ}$ dia.

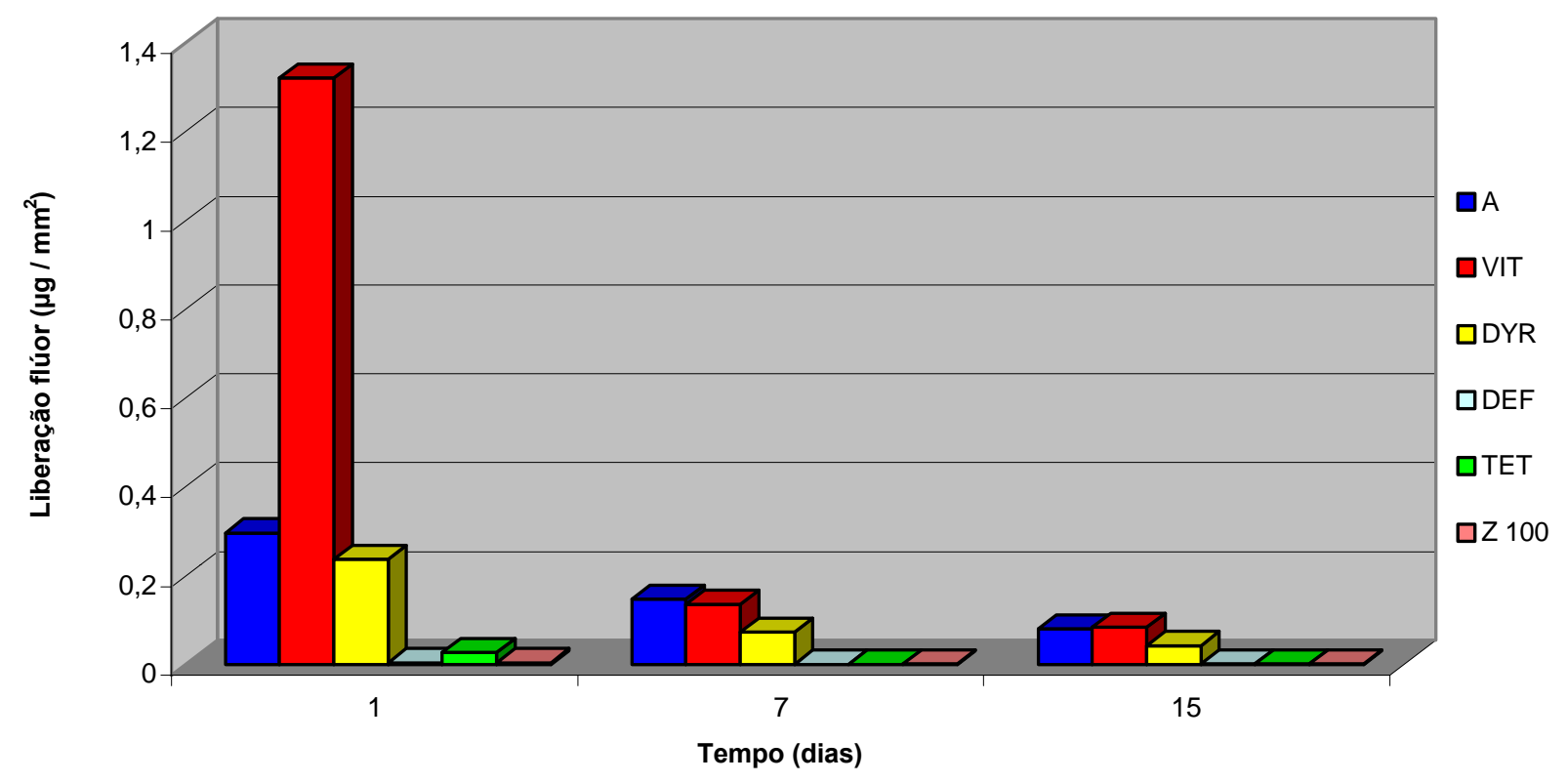

FIGURA 5.5 - Gráfico da média da quantidade de liberação de $\mathrm{F}$ em $\mu \mathrm{g} / \mathrm{mm}^{2}$ dos materiais restauradores, em $\mathrm{CpH}$, em 24 horas, nos $1^{\circ} \stackrel{0}{ } 7^{\circ}$ e $15^{\circ}$ dias 
A Figura 5.6 representa a distribuição total de flúor em $\mathrm{CpH}$, durante 15 dias.

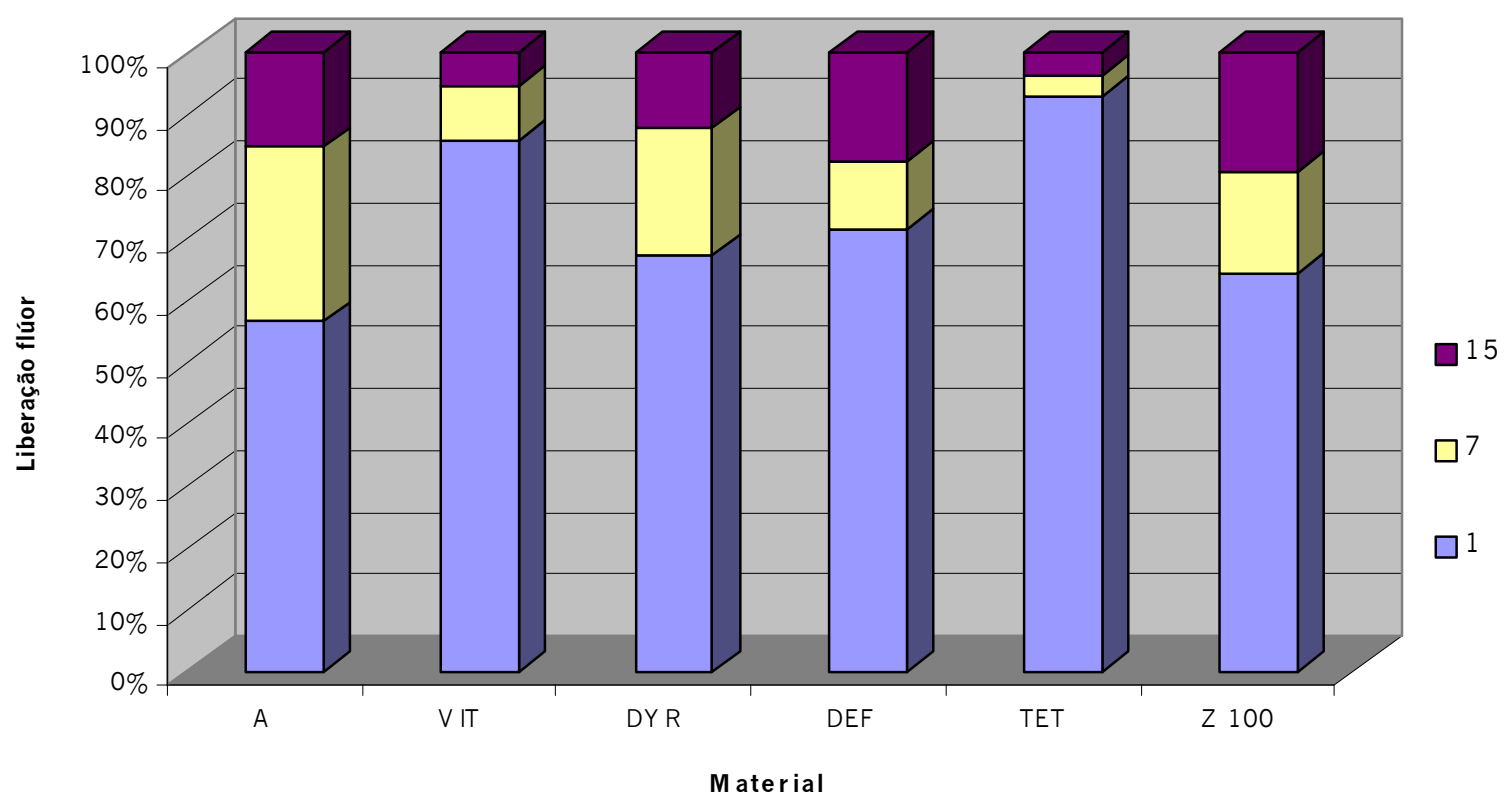

FIGURA 5.6 - Gráfico da distribuição total de liberação de flúor nos $1^{\circ}, 7^{\circ}$ e $15^{\circ}$ dias 
TABELA 5.8 -Comparação dos valores médios de liberação diária do $1^{\circ}$ dia, entre os grupos, em $\mathrm{H}_{2} \mathrm{O}$. (Teste de Tukey)

\begin{tabular}{|c|c|c|c|c|c|c|}
\hline Material & $\underset{0,3000 \mu \mathrm{gF} / \mathrm{mm}^{2}}{A}$ & $\begin{array}{c}\text { VIT } \\
0,6868 \mu \mathrm{g} / \mathrm{mm}^{2}\end{array}$ & $\begin{array}{c}\text { DYR } \\
0,0616 \mu \mathrm{gF} / \mathrm{mm}^{2}\end{array}$ & $\begin{array}{c}\mathrm{DEF} \\
0,0011 \mu \mathrm{gF} / \mathrm{mm}^{2}\end{array}$ & $\begin{array}{c}\text { TET } \\
0,0071 \mu \mathrm{F} / \mathrm{mm}^{2}\end{array}$ & $\begin{array}{c}Z_{100} 100 \\
0,0010 \mu \mathrm{gF} / \mathrm{mm}\end{array}$ \\
\hline A & &, $000123^{*}$ &, $003034^{*}$ &, $000162^{*}$ &, $000185^{*}$ &, $000162^{*}$ \\
\hline VIT &, $000123^{*}$ & &, $000123^{*}$ &, $000123^{*}$ &, $000123^{*}$ &, $000123^{*}$ \\
\hline DYR &, $003034^{*}$ &, $000123^{*}$ & & ,994718 ns & ,997914 ns & ,994708 ns \\
\hline DEF &, $000162^{*}$ &, $000123^{*}$ & ,994718 ns & & 1,000000 ns & 1,000000 ns \\
\hline TET &, $000185^{*}$ &, $000123^{*}$ & ,997914 ns & 1,000000 ns & & 1,000000 ns \\
\hline Z 100 &, $000162^{*}$ &, $000123^{*}$ & ,994708 ns & 1,000000 ns & 1,000000 ns & \\
\hline
\end{tabular}

* estatisticamente significante $(p<0,05)$.

ns diferenças estatisticamente não significantes.

TABELA 5.9 - Comparação dos valores médios de liberação diária do $7^{0}$ dia, entre os grupos, em $\mathrm{H}_{2} \mathrm{O}$. (Teste de Tukey)

\begin{tabular}{|c|c|c|c|c|c|c|}
\hline Material & $\begin{array}{c}A \\
0,2306 \mu \mathrm{gF} / \mathrm{mm}^{2} \\
\end{array}$ & $\begin{array}{c}\mathrm{VIT} \\
0,0531 \mu \mathrm{gF} / \mathrm{mm}^{2} \\
\end{array}$ & $\begin{array}{c}\text { DYR } \\
0,0097 \mu \mathrm{gF} / \mathrm{mm}^{2} \\
\end{array}$ & $\begin{array}{c}\text { DEF } \\
0,0006 \mu \mathrm{gF} / \mathrm{mm}^{2} \\
\end{array}$ & 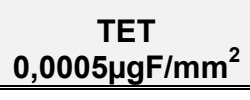 & $\begin{array}{c}Z_{100} \\
0,0005 \mu \mathrm{gF} / \mathrm{mm} \\
\end{array}$ \\
\hline A & &, $000123^{*}$ &, $000123^{*}$ &, $000123^{*}$ &, $000123^{*}$ &, $000123^{*}$ \\
\hline VIT &, $000123^{*}$ & & ,001835* &, $000165^{*}$ & $000162^{*}$ & $000162^{*}$ \\
\hline DYR &, $000123^{*}$ &, $001835^{*}$ & & ,998793 ns & ,998599 ns & ,998633 ns \\
\hline DEF &, $000123^{*}$ &, $000165^{*}$ & 0,998793 ns & & 1,000000 ns & 1,000000 ns \\
\hline TET &, $000123^{*}$ &, $000162^{*}$ & 0,998599 ns & 1,000000 ns & & 1,000000 ns \\
\hline Z 100 &, $000123^{*}$ &, $000162^{*}$ & 0,998633 ns & 1,000000 ns & 1,000000 ns & \\
\hline
\end{tabular}

* estatisticamente significante $(p<0,05)$

ns diferenças estatisticamente não significantes 
TABELA 5.10 - Comparação dos valores médios de liberação diária do 15ํㅡㄹ dia, entre os grupos, em $\mathrm{H}_{2} \mathrm{O}$. (Teste de Tukey)

\begin{tabular}{|c|c|c|c|c|c|c|}
\hline Material & $\underset{0,2430 \mu \mathrm{gF} / \mathrm{mm}^{2}}{A}$ & $\begin{array}{c}\text { VIT } \\
0,0371 \mu \mathrm{gF} / \mathrm{mm}^{2}\end{array}$ & $\begin{array}{c}\text { DYR } \\
0,0070 \mu \mathrm{gF} / \mathrm{mm}^{2}\end{array}$ & $\begin{array}{c}\text { DEF } \\
0,0003 \mu \mathrm{gF} / \mathrm{mm}^{2}\end{array}$ & $\begin{array}{c}\text { TET } \\
0,0005 \mu \mathrm{gF} / \mathrm{mm}^{2}\end{array}$ & $\begin{array}{c}Z 100 \\
0,0005 \mu \mathrm{gF} / \mathrm{mm}\end{array}$ \\
\hline A & &, $000123^{*}$ &, $000123^{*}$ &, $000123^{*}$ &, $000123^{*}$ & ,000123* \\
\hline VIT &, $000123^{*}$ & & ,000189* &, $000123^{*}$ &, $000123^{*}$ & ,000123* \\
\hline DYR & ,000123* & ,000189* & & ,991166 ns & ,993262 ns & ,993036 ns \\
\hline DEF & ,000123* & ,000123* & ,991166 ns & & 1,000000 ns & 1,000000 ns \\
\hline TET &, $000123^{*}$ &, $000123^{*}$ & ,993262 ns & 1,000000 ns & & 1,000000 ns \\
\hline Z 100 & ,000123* & ,000123* & ,993036 ns & 1,000000 ns & 1,000000 ns & \\
\hline
\end{tabular}

${ }^{*}$ estatisticamente significante $(p<0,05)$

ns diferenças estatisticamente não significantes

TABELA 5.11 - Comparação dos valores médios de liberação diária do $1^{0}$ dia, entre os grupos, em CPH. (Teste de Tukey)

\begin{tabular}{|c|c|c|c|c|c|c|}
\hline Material & $\begin{array}{c}A \\
0,2972 \mu \mathrm{gF} / \mathrm{mm}^{2} \\
\end{array}$ & $\begin{array}{c}\mathrm{VIT} \\
1,3212 \mu \mathrm{gF} / \mathrm{mm}^{2} \\
\end{array}$ & $\begin{array}{c}\text { DYR } \\
0,2384 \mu \mathrm{FF} / \mathrm{mm}^{2} \\
\end{array}$ & $\begin{array}{c}\text { DEF } \\
0,0045 \mu \mathrm{gF} / \mathrm{mm}^{2} \\
\end{array}$ & $\begin{array}{c}\text { TET } \\
0,0276 \mu \mathrm{gF} / \mathrm{mm}^{2} \\
\end{array}$ & $\begin{array}{c}Z 100 \\
0,0043 \mu \mathrm{gF} / \mathrm{mm} \\
\end{array}$ \\
\hline A & &, $000123^{*}$ & ,995917 ns & ,000186* & ,000484* & ,000185* \\
\hline VIT &, $000123^{*}$ & & ,000123* &, $000123^{*}$ & ,000123* &, $000123^{*}$ \\
\hline DYR & ,995917 ns & $000123^{*}$ & & ,003959* &, $015041^{*}$ &, $003904^{*}$ \\
\hline DEF &, $000186^{*}$ &, $000123^{*}$ & ,003959* & & 1,000000 ns & 1,000000 ns \\
\hline TET & ,000484* & ,000123* &, $015041^{*}$ & 1,000000 ns & & 1,000000 ns \\
\hline Z 100 &, $000185^{*}$ &, $000123^{*}$ &, $003904^{*}$ & 1,000000 ns & 1,000000 ns & \\
\hline
\end{tabular}

* estatisticamente significante $(p<0,05)$

ns diferenças estatisticamente não significantes 
TABELA 5.12 - Comparação dos valores médios de liberação diária do $7^{0}$ dia, entre os grupos, em CPH. (Teste de Tukey)

\begin{tabular}{|c|c|c|c|c|c|c|}
\hline Material & $\begin{array}{c}\text { A } \\
0,1481 \mu \mathrm{gF} / \mathrm{mm}^{2}\end{array}$ & $\begin{array}{c}\text { VIT } \\
0,1364 \mu \mathrm{gF} / \mathrm{mm}^{2}\end{array}$ & 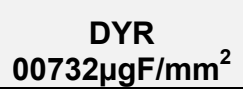 & $\begin{array}{c}\text { DEF } \\
0,0007 \mu \mathrm{gF} / \mathrm{mm}^{2}\end{array}$ & $\begin{array}{c}\text { TET } \\
0,0010 \mu \mathrm{gF} / \mathrm{mm}^{2}\end{array}$ & $\begin{array}{c}Z_{1100} \\
0,0011 \mu \mathrm{gF} / \mathrm{mm}\end{array}$ \\
\hline A & & 988479 ns & $000123^{*}$ & $000123^{*}$ & $000123^{*}$ & $000123^{*}$ \\
\hline VIT & ,988479 ns & & ,000123* & ,000123* & ,000123* & ,000123* \\
\hline DYR & 000123* & $000123^{*}$ & & ,003959* & 000123* & $000123^{*}$ \\
\hline DEF & $000123^{*}$ & ,000123* & 000123* & & 1,000000 ns & 1,000000 ns \\
\hline TET & $000123^{*}$ &, $000123^{*}$ & $000123^{*}$ & 1,000000 ns & & 1,000000 ns \\
\hline Z 100 & $000123^{*}$ & ,000123* & $000123^{*}$ & 1,000000 ns & 1,000000 ns & \\
\hline
\end{tabular}

* estatisticamente significante $(p<0,05)$

ns diferenças estatisticamente não significantes

TABELA 5.13 - Comparação dos valores médios de liberação diária do 15ํํㄹ dia, entre os grupos, em $\mathrm{CPH}$. (Teste de Tukey)

\begin{tabular}{|c|c|c|c|c|c|c|}
\hline Material & $\begin{array}{c}A \\
0,0805 \mu \mathrm{F} / \mathrm{mm}^{2} \\
\end{array}$ & $\begin{array}{c}\text { VIT } \\
0,0835 \mu \mathrm{gF} / \mathrm{mm}^{2} \\
\end{array}$ & $\begin{array}{c}\text { DYR } \\
0,0429 \mu \mathrm{gF} / \mathrm{mm}^{2} \\
0\end{array}$ & $\begin{array}{c}\text { DEF } \\
0,0011 \mu \mathrm{gF} / \mathrm{mm}^{2} \\
\end{array}$ & 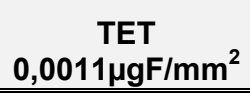 & $\begin{array}{c}Z 100 \\
0,0013 \mu \mathrm{gF} / \mathrm{mm}\end{array}$ \\
\hline A & & 999997 ns & $000123^{*}$ & $000123^{*}$ & $000123^{*}$ & $000123^{*}$ \\
\hline VIT & ,999997 ns & &, $000123^{*}$ &, $000123^{*}$ &, $000123^{*}$ &, $000123^{*}$ \\
\hline DYR & 000123* & $000123^{*}$ & &, $000123^{*}$ & $000123^{*}$ & 000123* \\
\hline DEF & 000123* &, $000123^{*}$ & 000123* & & 1,000000 ns & 1,000000 ns \\
\hline TET & $000123^{*}$ & ,000123* & $000123^{*}$ & 1,000000 ns & & 1,000000 ns \\
\hline Z 100 & $000123^{*}$ &, $000123^{*}$ & $000123^{*}$ & 1,000000 ns & 1,000000 ns & \\
\hline
\end{tabular}

* estatisticamente significante $(p<0,05)$

ns diferenças estatisticamente não significantes 
6 DISCUSSÃO 


\section{DISCUSSÃO}

Desde o aparecimento do cimento de silicato e do cimento de ionômero de vidro, novos materiais restauradores com liberação de flúor foram surgindo na tentativa de conciliar materiais estéticos com melhores propriedades mecânicas e biológicas ${ }^{1,2,5,35}$. Nesta linha de investigações surgiram vários materiais entre os quais encontramos o cimento de ionômero de vidro modificado por resina e a resina composta modificada por poliácidos.

Face à evolução das resinas compostas e ao aumento da sua aplicabilidade clínica, cresceu cada vez mais o interesse em transformá-las num veículo de liberação de flúor em meio bucal, adequando esses materiais às reais necessidades.

Essa liberação em concentrações mínimas e constantes é considerada mais efetiva ${ }^{39}$, por diminuir a solubilidade do esmalte ${ }^{59}$ inibindo a desmineralização e potencializando a remineralização ${ }^{62}$ no esmalte adjacente nas margens cavitárias e na dentina subjacente às restaurações ${ }^{18,44}$.

A ação do flúor no esmalte dá- se pela reação com a hidroxiapatita que contém carbonatos e fosfatos, formando fluorapatita que possui uma grade espacial mais estável, o que lhe confere maior resistência ao ataque ácido ${ }^{41}$. A interpretação é que ao dissolver-se, a fluorapatita libera íons de F e de cálcio formando fluoreto de 
cálcio que recobre os cristais não dissolvidos, interferindo na difusão do ácido no cristal e diminuindo a saída dos íons de $\mathrm{Ca}^{++}$e fósforo na estrutura dentária.

Outra ação do flúor está na sua propriedade antibacteriana, contribuindo na redução do acúmulo de placa sobre a restauração 4,3,21,36,39,59. Tem sido comprovado que o flúor apresenta uma ação antienzimática sobre as bactérias 14,25,32. Esses fatores agem sinergicamente reduzindo o aparecimento de cáries secundárias e estabelecendo maior longevidade das restaurações.

Portanto, os materiais restauradores que liberam flúor podem contribuir para o equilíbrio do $\mathrm{pH}$ crítico bucal ${ }^{64}$, reduzindo os períodos de desmineralização e, tornando mais freqüentes e mais longos os ciclos de remineralização, principalmente no esmalte adjacente às restaurações.

Diante deste desafio, torna-se interessante 0 desenvolvimento de modelos de estudos laboratoriais na simulação de condições capazes de reproduzir situações clínicas, na busca de informações sobre o comportamento dos materiais restauradores nessas condições. De acordo com FEATHERSTONE ${ }^{26}$, uma das formas de se reproduzir uma situação dinâmica natural do desafio ácido ao esmalte dentário é realizando-se in vitro ciclos de desmineralização e remineralização, durante 15 dias, também elaborada por CARVALHO ${ }^{26}$, embora seja difícil a reprodução perfeita das condições da cavidade bucal ${ }^{62,24}$

A liberação de flúor dos materiais estudados foi avaliada em 2 meios de imersão: água deionizada e ciclagem de $\mathrm{pH}(\mathrm{CpH})$, expondo o material restaurador a uma situação de alto risco. 
Os ensaios realizados em água deionizada, quantificam a liberação total de íons $\mathrm{F}^{-}$no meio, sem a interferência da saliva, ou seja, livre da força iônica de diversos outros elementos existentes no fluído salivar ${ }^{54}$.

A ciclagem de $\mathrm{pH}$ é feita em 2 fases durante 24 horas. O período de 6 horas em solução DES', representa a condição de pessoas expostas ao desafio ácido por "beliscarem" alimentos várias vezes durante o dia, reduzindo o $\mathrm{pH}$ dos níveis de 5,5 para $4,5^{64}$, tornando o meio bucal favorável aos ciclos de desmineralização e favorecendo a instalação e progressão das lesões de cárie. 0 ciclo de remineralização de 18 horas in vitro, corresponde ao período de recuperação in vivo que ocorre na presença da saliva.

O padrão de liberação de flúor dos materiais testados nos meios de imersão, água deionizada e ciclagem de pH, está em concordância com a literatura pesquisada ${ }^{3,13,32,58,63}$. No primeiro dia do presente experimento foi observado o maior pico de liberação em todos os materiais (Tabela 5.1 e 5.2, Gráfico 5.1a, 5.1b, 5.2a, 5.2b), que declinou no segundo dia, atingindo níveis constantes em torno do 5ํㅡㄴ ao $7^{0}$ dia, ocorrendo ainda pequenas variações até o final do experimento, no décimo quinto dia, exceto para o Ariston.

Esse padrão foi também observado nos trabalhos de $\mathrm{ABOUSHL}^{1}$ (1998), BACH $^{8}$ (1997), CARVALHO ${ }^{12}$ (1995), GROBEER ${ }^{36}$ (1998) que avaliaram a liberação de fluoretos dos ionômeros de vidro modificado por resinas, resinas modificadas por poliácidos e resinas compostas. 
Com relação aos meios de imersão, o de $\mathrm{CpH}$ proporcionou maior liberação de flúor quando comparado com o de água deionizada para todos os materiais, exceto o Ariston, no qual a maior liberação foi na água.

O material Ariston foi lançado mais recentemente, e ainda pouco citado, tendo sido testado mais no âmbito clínico e microbiológico, não sendo possível amplas comparações com os outros resultados de liberação existentes na literatura. Analisando as informações do fabricante ${ }^{4}$, os testes de liberação de flúor foram elaborados em água deionizada e em soluções com pH 4,0 e 7,2, simulando a condição bucal. Os valores liberados foram, inicialmente considerados ,em 24 horas para cada solução de armazenamento, seguidos de valores semanais até completar 12 semanas. Comparando o padrão de liberação do Ariston em água deionizada, e nas soluções de $\mathrm{pH}$ 4,0 e pH 7,2, e projetando o período de 24 horas para cada uma das soluções aqui estudadas, concluímos em nosso experimento que o material testado apresenta o mesmo padrão de liberação encontrado pelo fabricante nos 3 meios de armazenamento, ou seja são liberados mais íons em ambiente ácido ( $\mathrm{pH}$ $4,0)$ que em ambiente neutro, $\mathrm{pH} 6,8{ }^{37}$.

Em comparação com os compômeros, o material apresenta uma maior liberação tanto em água como em ciclagem de $\mathrm{pH}$, em concordância com os resultados de HEINTZE ${ }^{37}$.

A estrutura química do Ariston, é a de uma resina composta com moléculas possuindo radicais de monômeros dimetacrilatos e cargas inorgânicas (vidro de fluorossilicato de bário e alumínio, trifluoreto de itérbio, e dióxido de silício). Suas características especiais são as cargas vítreas alcalinas adicionais, um vidro 
de silicato de cálcio que libera íons de flúor e cálcio. Essa liberação está associada a queda do $\mathrm{pH}$ salivar., segundo o fabricante ${ }^{4}$. O material em contato com a água libera íons hidroxila pela sua superfície, íons que atuam como tampão ${ }^{37}$.

O Ariston tanto em água deionizada como em ciclagem de $\mathrm{pH}$, revelou ter uma liberação de flúor constante em concentrações estáveis, diferindo das resinas e dos outros materiais testados. Em água apresentou um declínio do $1^{\circ}$ ao $3^{\circ}$ dia $\left(0,3000 \mu \mathrm{gF}^{-} / \mathrm{mm}^{2}\right.$ a $\left.0,1614 \mu \mathrm{gF}^{-} / \mathrm{mm}^{2}\right)$, com uma diminuição em torno de $50 \%$ e, a partir do $5^{\circ}$ dia, os valores liberados tornaram-se praticamente constantes, variando de $0,2689 \mu \mathrm{gF}^{-} / \mathrm{mm}^{2}$ a $0,2430 \mu \mathrm{gF}^{-} / \mathrm{mm}^{2}$ até o final do experimento (Gráfico 5.1a). Na ciclagem de $\mathrm{pH}$, o nível de $\mathrm{F}^{-}$liberado inicialmente foi de 0,2972 $\mu \mathrm{g} \mathrm{F}^{-} / \mathrm{mm}^{2}$, superior em relação a todos os materiais, exceto para o Vitremer $^{\mathrm{TM}}$ no $1^{\circ}$ dia $(1,3712$ $\mu \mathrm{g} \mathrm{F}^{-} / \mathrm{mm}^{2}$ ), porém com diferença estatisticamente siginificante. (Tabela 5.3, Gráfico 5.5). O declínio da liberação foi muito lento, caracterizando uma liberação lenta e constante como na água deionizada (Gráfico 5.2a),

O Vitremer ${ }^{\mathrm{TM}}$ é um cimento de ionômero de vidro de ativação tripla, composto basicamente de pó de vidro de silicato de flúor-alumínio e, o líquido constitui um sistema aquoso de ácido policarboxílico modificado 6,25,36,43,48,58,65. Esse material apresentou a maior liberação no $1^{\circ}$ dia independentemente do meio de armazenamento. Uma característica marcante é a queda brusca nos valores de $\mathrm{F}^{-}$ liberado nas 48 horas após contato com as soluções utilizadas. De acordo com a literatura $^{3,11,32,36,42,58}$, esse comportamento sempre é observado no Vitremer. A razão da queda rápida na liberação de flúor é decorrente da grande liberação inicial 
a partir das partículas de vidro que são dissolvidas parcialmente no ácido polialcenóico, durante a reação de endurecimento ${ }^{53}$.

Em nosso experimento, esse declínio foi observado na água deionizada e em $\mathrm{CpH}$, sendo liberadas nas primeiras 48 horas as maiores concentrações de forma estatisticamente significante em relação a todos os materiais testados em ambos os meios de imersão, e estando de acordo com os achados de CARVALHO; CURY ${ }^{12,13}$ encontrado na literatura. Esse padrão de liberação é encontrado normalmente para esses materiais e, sendo também, largamente citado na literatura $3,11,12,13,32,36,42,58$.

O Dyract é uma resina composta modificada por poliácidos constituída de partículas de vidro de aluminio flúor-silicato e estrôncio em uma matriz de monômeros ${ }^{18,25}$ de UDMA que se une ao ácido butano tetracarboxílico (TBC) e com o HEMA com polimerização ativada por luz ${ }^{6,18,43,48,58}$.

Esse material apresentou a maior liberação ao $1^{\circ}$ dia, independente do meio de armazenamento, padrão este de todos os materiais estudados e de acordo com a literatura ${ }^{3,32,58}$. Nos compômeros e resinas compostas a liberação é dada pelo mecanismo de difusão, porém muito pequena, sendo o grau de solubilidade das resinas muito baixo ${ }^{63}$.

Na água deionizada o Dyract mostrou diferenças estatisticamente não significantes com relação aos materiais DEF, TET e Z 100, mas estatisticamente significante frente ao Ariston e Vitremer ${ }^{\mathrm{TM}}$. Em CpH ocorreu a maior liberação no $1^{\circ}$ dia, estatisticamente significante $(p<0,05)$ para o VIT, DEF, TET, Z 100, mas diferenças estatisticamente não significante ao Ariston no $1^{\circ}$ dia. Nos intervalos de 7 
e 15 dias não houve diferenças estatisticamente significantes. A partir do $7^{\circ}$ dia, essa liberação já era bem menor, estabilizando-se a níveis mais baixos. Esse declínio está de acordo com os dados obtidos por FORSTEN ${ }^{30}$. Os dados estão compatíveis com os de $\mathrm{ARAÚJO}^{3}$ em cujo experimento, os materiais também sofreriam trocas diárias a cada 24 horas e permaneciam sob agitação em água deionizada. Nas resina composta modificada por poliácido, primeiro ocorre a fase de polimerização, seguida pela absorção de água, formando mais tarde ligações químicas no material por meio de reações ácido-base, ocorrendo então a liberação de flúor ${ }^{25}$. Portanto esses materiais apresentam um comportamento mais próximo ao da resina composta do que o observado no de um cimento de ionômero de vidro $^{1,6,58}$.

Com relação ao meio, comparando-se água deionizada e $\mathrm{CpH}$, houve maior liberação em $\mathrm{CpH}$ do que em água, resultados que são semelhantes aos de ATTIN $^{5}$ e GEURSTEN ${ }^{33}$, que trabalharam com soluções ácidas e não com $\mathrm{CpH}$ mas, por outro lado confirmam os resultados obtidos por CARVALHO e CURY ${ }^{12}$ que usaram o mesmo método empregado no presente trabalho. Nos resultados obtidos por GEURSTEN ${ }^{33}$, o Dyract liberou quantidade semelhante tanto na água quanto na solução pH 4,2 com trocas de 48 horas. Segundo alguns autores o período de estocagem e o intervalo de tempo na troca de solução pode interferir na liberação de íons de flúor, estando de acordo também com os trabalhos de CARVALHO e CURY ${ }^{13}, \mathrm{XU}^{66}{ }^{66}$ BERTACCHIN ${ }^{8}$. Mesmo apresentando uma baixa quantidade de liberação quando comparado ao Vitremer ${ }^{\mathrm{TM}}$, tanto o $\mathrm{CIV}$ modificado por resina como a resina modificada por poliácidos podem prevenir cárie secundária ao redor da restauração e lesões de cáries iniciais na superfície do esmalte adjacente às restaurações 
segundo os estudos de DYONYSOPOULOS ${ }^{18}$, e por conseguinte uma menor área desmineralizada $^{19,}$ mas que é maior quando comparada com CIV convencional ${ }^{46}$.

Revisando a literatura nesse campo, MCCABE ${ }^{48}$ constatou que se tem observado que a liberação dos CIV híbridos é semelhante à dos CIV convencional. As resinas compostas com liberação de flúor e as resinas compostas modificadas por poliácidos liberam menores quantidades, mas a longo prazo os CIV modificados por resina atingem valores semelhantes ao compômero. Esse comportamneto foi também observado nesse nosso trabalho e poder ser constatado no Gráfico 5.1a e $5.1 \mathrm{~b}$ ao $15^{\circ}$ dia.

Como as resinas compostas modificadas por poliácidos não apresentam uma grande liberação inicial da mesma forma que ocorre com os cimentos de ionômero de vidro modificados por resina, que apresentam um declínio acentuaudo inicial, esse material atinge rapidamente níveis idênticos aos liberados pelos compômeros, que representam uma liberação mais constante como também observou SHAW ${ }^{55}$. Desta forma, ainda não foi relacionado que efeito é mais importante na prevenção da cárie: a explosão inicial ou a liberação de flúor prolongada pelos compômeros ${ }^{55}$.

A fonte de liberação de flúor das resinas compostas modificadas por poliácidos está nos componentes na matriz resinosa como no $\mathrm{YbF}_{3}$, bem como, nas cargas de vidro, flúor-alumínio-silicato de vidro e fluoreto de estrôncio ${ }^{34}$.

Os resultados obtidos em nosso estudo estão em concordância com os encontrados por VIEIRA ${ }^{64}$, que testou os materiais Vitremer ${ }^{\mathrm{TM}}$ e Dyract em ciclos de desmineralização e remineralização durante 14 dias, simulando o desafio 
cariogênico. A maior liberação ocorreu na solução desmineralizante em comparação com a solução remineralizante. Segundo o autor, essa liberação durante o desafio cariogênico, previne uma maior perda mineral do esmalte em decorrência da liberação de flúor por parte dos materiais. São 2 processos que ocorrem: erosão superficial de forma rápida e a difusão contínua de íons do corpo do material, permanecendo mais tempo, decorrente da baixa velocidade com que se processa a difusão.

Outro material avaliado neste estudo foi o Definite ${ }^{\circledR}$, que é uma resina composta híbrida contendo partículas de vidro de bário, estabilizantes, sulfo-fosfato de apatita e a matriz ormocer fotopolimerizável definida como cerâmica modificada organicamente, apresentando como matriz inorgânica de polisiloxano. Essa matriz é caracterizada por blocos formados por uma poli-siloxana covalentemente combinada por átomos de silício aos grupos de metacrilatos fotopolimerizáveis.

O comportamento do material segue o mesmo padrão de liberação, sendo maior no $1^{\circ}$ dia, declinando a níveis constantes em ambos os meios, enquanto na $\mathrm{CpH}$ foi ligeiramente maior do que em água deionizada (Tabela 5.3, Gráficos 5.3 e 5.5). Da mesma forma que as demais resinas, comparando os valores médios no período de 1,7 e 15 dias e os meios de imersão, observaram-se diferenças estatisticamente não significantes com Dyract, Tetric $^{\circledR}$ Ceram, Z 100 na água e, com Tetric $^{\circledR}$ Ceram e Z100 em CpH (Tabela 5.8 a 5.13).

O material Definite ${ }^{\circledR}$, segundo o fabricante, tem a apatita modificada presente em sua formulação em $3 \%$, com a função de promover a liberação e recarga de flúor, além de tampão ácido. Esta propriedade está na dependência da 
adição de flúor por fontes externas como dentifrícios ou outras substâncias que contenham o íon ${ }^{16,38}$. Os resultados obtidos neste trabalho estão compatíveis com os apresentados na literatura ${ }^{6} \mathrm{com}$ as resinas compostas. Comparando com os outros materiais, os maiores valores foram obtidos no $1^{\circ}$ e $8^{\circ}$ dias $\left(0,0011 \mu \mathrm{gF}^{-} / \mathrm{mm}^{2}\right)$ (Gráfico 51b). Tanto nos meios de água deionizada e $\mathrm{CpH}$, a liberação de flúor foi muito baixa. Ao comparar com os resultados obtidos da liberação de flúor nos tempos de 1, 7 e 15 dias, em ambos os meios, os valores foram comparáveis aos da resina Z100.

O Tetric ${ }^{\circledR}$ Ceram é uma resina composta híbrida de partículas finas, tendo sido encontrados poucos trabalhos avaliando a liberação de flúor ${ }^{31,66}$. A matriz de monômero é composta de Bis-GMA, UDMA e TEGDMA e a carga inorgânica contém vidro de bário, $\mathrm{YbF}_{3}$ em torno de $15 \%$, vidro de fluorsilicato de alumínio e bário, dióxidode silício e óxidos mistos esferoidais ${ }^{1,25}$.

Os resultados obtidos em nosso estudo estão de acordo com os mostrados na literatura. No trabalho de $\mathrm{YAP}^{68}$, este material apresentou a mais baixa liberação com relação aos demais materiais estudados.

A resina Z100 é composta de BisGMA e TEGDMA e carga inorgânica de zircônio e sílica. No presente trabalho e em comparação com os outros materiais, a resina Z 100 apresentou liberação de flúor, porém com diferenças estatisticamente não significantes em relação ao Definite e Tetric Ceram, materiais com carga inorgânica contendo flúor, citados em alguns estudos como materiais capazes de liberar flúor, talvez decorrente da presença de $\mathrm{YbF}_{3}$, como substância catalisadora, segundo o fabricante ${ }^{31}$. 
Os estudos de análises quantitativas e qualitativas de liberação de flúor citadas na literatura são realizados por diversas metodologias que dificultam a possibilidade de comparações, além de na sua maioria serem realizados in vitro, situação que não reproduz a realidade do meio bucal, mesmo quando se usa a ciclagem de $\mathrm{pH}^{23}$.

A comprovação da liberação de flúor pelos materiais estéticos estudados no presente trabalho demonstra o direcionamento da evolução dos materiais restauradores ${ }^{20,57,69}$. As melhores propriedades mecânicas das resinas compostas associadas às qualidades do flúor como, a capacidade de redução no acúmulo de placa por ação enzimática e a ação na diminuição da solubilidade do esmalte traduzem-se na expectativa de um arma eficiente na manutenção de maior longevidade clínica das restaurações e na própria saúde bucal.

É importante salientar que o contexto preventivo na Odontologia requer procedimentos que previnam a instalação da cárie. O desenvolvimento dos materiais restauradores não pode ser visto como solução definitiva, mas auxiliar. Além disto, a recarga que as diversas substâncias que contém flúor permitem aos materiais restauradores ${ }^{20,58}$ e que não foi alvo deste estudo, poderá ser um aliado adicional na prevenção. Obviamente, as modificações decorrentes de novas formulações podem abrir caminho para o estabelecimento de mais uma categoria de material restaurador, que seja um verdadeiro e permanente reservatório de flúor. 
7 CONCLUSÕES 


\section{CONCLUSÕES}

Em face aos resultados obtidos na realização do presente trabalho, parece-nos lícito concluir que:

7.1 Em relação ao fator tempo, todos os materiais estudados desenvolveram um padrão semelhante de liberação de flúor.

7.1.1 Houve uma liberação acentuada no primeiro dia com declínio significativo no segundo, decréscimo lento até o sétimo dia e então mantendo-se um nível constante até o décimo quinto dia.

7.1.2 Comportando-se de maneira diferente, o material Ariston apresentou liberação constante de flúor durante os quinze dias, nos dois meios de imersão.

7.2 Nos ensaios em água deionizada, todos os materiais liberaram flúor. Quando comparados ao controle positivo, o material Vitremer, o material Ariston apresentou a maior liberação, enquanto os materiais Dyract, Tetric Ceram e Definite liberaram menor quantidade, tendo o material Z-100, o controle negativo, sido o que menos flúor liberou.

7.3 Nos ensaios em ciclagem de $\mathrm{pH}$, houve uma tendência em todos os materiais, exceto o Ariston de maior liberação de flúor que nos ensaios em água deionizada. O material Vitremer apresentou a maior liberação e, em relação ao 
controle negativo, o material Z100, as resinas Tetric Ceram e Definite não apresentaram diferenças estatisticamente significantes sendo que o material Definite liberou menos Fluor que o material Z100. 
REFERÊNCIAS BIBLIOGRÁFICAS 


\section{REFERÊNCIAS BIBLIOGRÁFICAS}

1 ABOUSH, Y.E.Y.; TORABZADEH, H. Fluoride release from tooth colored restorative materials a 12 month report. J. Canad. dental. Ass. v. 64, n. 8, p. 561-4, 568, Sept. 1998.

2 AMERICAN DENTAL ASSOCIATION. Restorative materials containing fluoride: Council on Dental Materials, Instruments, and Equipment. J. Amer. dent. Ass. v.116, n. 6, p. 762-3, May 1988

3 ARAÚJO, F.B.de et al. Fluoride release from fluoride-containing materials. Oper. Dent. v. 21, n. 5, p.185-90, Sep.-Oct. 1996.

4 Ariston pHc - Documentación científica Ariston pHc, Vivadent 1998.

5 ATTIN, T. et al. Fluoride release /uptake of poliacid-modified resin composite compomers in neutral and acid buffer solutions. J. oral Rehab. v. 26, n. 5, p. 88-93, May 1999.

6 BALA, O. et al. Fluoride release from various restorative materials. J. Nihon Univ. Sch. Dent. v. 39, n. 3, p.123-7, Sep. 1997.

7 BELL, A. et al. The effect of saliva on fluoride release by a glass-ionomer filling material. J. oral Rehab. v. 26, n. 5, p. 407-12, May 1999. 
8 BERTACCHIN, S.M. et al. Solubility and fluoride release in ionomers and compomers. Quintessence Int. v. 30, n. 3, p. 193-7, Mar. 1999.

9 BILGIN, Z.; OZALP, N. Fluoride release from three different types of glass ionomer cements after exposure to NaF solution and APF gel. J. clin. Pediat. Dent. v.22, n. 3, p. 237-41, Spring. 1998.

10 BUZALAF, M.A.R.; TAGA, E.M.; SOUTO, E.C. Influence of hydroxyapatite on fluoride release from composite resins. J. dent. Res. v. 77, n. 5, p. 1143, May, 1998.

11 CAO, D.S. et al. Fluoride release from glass ionomer/resins \& composites J. dent. Res. v. 73, n. Spec. Issue(Abstract); p. 184, 1994.

12 CARVALHO, A.S.; CURY, J.A. Fluoride release from some dental materials in different solutions. Oper. Dent. v. 24, n. 1, p. 14-9, Jan.-Feb. 1999.

13 CARVALHO, A.S.; CURY, J.A. Liberação de flúor de materiais restauradores. Rev. Odont. USP v. 12, n. 4, p.367-373, out./dez. 1998.

14 COSTA, B. et al. Estudo comparativo da liberação de flúor de materiais dentários restauradores. Rev. Odont. USP v. 9, n. 4, p.279-84,out./dez.1995.

15 CREANOR, S. L. et al. Fluoride uptake and release characteristics of glassionomer cements. Caries Res. v. 28, n. 5, p. 322-8, Sept.-Oct. 1994.

16 Definite® - Technical manual (V1)., Degussa, June 1998. 
17 DESCHEPPER, E. et al. A comparative study of fluoride release from glassionomer cements. Quintessence Int. v. 22, n. 3, p. 215-219, Mar, 1991.

18 DIONYSOPOULOS, P. et al. Artificial secondary caries around two new Fcontaining restoratives. Oper. Dent. v.23, n 2, p. 81-86, Mar./Apr., 1998

19 DONLY, K.J.; GRANDGENETT, C. Dentin demineralization inhibition at restoration margins of Vitremer, Dyract and Compoglass. Amer. J. Dent. v. 11 , n. 5, p. 246-248, Oct. 1998.

20 DONLY, K.J.; NELSON, J.J. Fluoride release of restorative materials exposed to a fluoridated dentrifice. J. Dent. Child. v. 64, n. 4, p. 249-50, July-Aug. 1997.

21 DONLY, K.J.et al. Enamel and dentin-demineralization inhibition of fluoride releasing materials. Amer. J. Dent. v. 7, n. 5, p. 275-8, Oct.. 1994.

22 DONLY, K. J.; GOMEZ, C. In vitro demineralization-remineralization of enamel caries at restoration margins utilizing fluoride releasing composite resin. Quintessence Int. v. 25, n. 5, p. 355-8, May. 1994.

23 EICHMILLER, F.C.; MARJENHOFF, W.A. Fluoride releasing dental restorative materials. Oper.Dent. v. 23, n. 5, p. 218-8, Sep.-Oct. 1998.

24 ERICKSON,. Model investigations of caries inhibition by fluoride-realeasing dental materials. Advanc. dent. Res. v. 9, n. 3, p.315-23, Nov. 1995. Discussion 324-31. 
25 FARAH, J.W.; POWERS, J.M. Fluoride-releasing restorative materials. Dent. Adv. v. 15, n. 10, p. 2-5, Dec. 1998.

26 FEATHERSTONE, J.D.B. et al. Enhancement of remineralization in vitro and in vivo. In: $\mathrm{LEACH}$, S.A. Factors relating to demineralization and remineralization of the teeth Oxford: IRL Press p. 23-34, 1986.

27 FORSTEN, L. Fluoride release and uptake by glass-ionomers and related material and its clinical effect. Biomaterials v. 19, n. 6, p 503-8, 1998.

28 FORSTEN, L. Resin-modified glass ionomer cements: fluoride release and uptake. Acta odont. scand. v. 53, n. 4, p. 222-225, Aug. 1995.

29 FORSTEN, L. Fluoride release of glass ionomers. J. Esthet. Dent. v. 6, n. 5, p 216-22 1994

30 FORSTEN, L. Short - and long-term fluoride release from glass ionomers and other fluoride-containing filling materials in vitro. Scand. J. dent. Res. v. 98, p.179-185, 1990.

31 FRANCCI, C. et al. Fluoride release from restorative materials and its effects on dentin demineralization. J. dent. Res. v. 78, n. 10, p. 1647-1654, Oct. 1999.

32 FRIEDL, K.H. et al. Resin-modifed glass ionomer cements: fluoride release and influence on Streptococus mutans growth. Eur. J. Oral Sci. v. 105, n. 1, p.815, Feb. 1997. 
33 GEURTSEN, W. Substances released from dental resin composites and glass ionomer cements. Eur. J. Oral Sci. v. 106, p. 687-95, Apr. 1998.

34 GEURSTEN, W.; LEYHAUSEN, G.; GARCIA-GODOY, F. Effect of storage media on the fluoride release and surface microhardness of four polyacid-modified composite resins ("compomers"). Dent. Mat. v. 15, p. 196-201, 1999,

35 GRIFFIN, F.; DONLY, K.J.; ERICKSON, R. Caries inhibition by fluoride-releasing liners. Amer. J. Dent.. v. 5, n. 6, p.293-295, Dec. 1992.

36 GROBLER, S.R.; ROSSOUW, R.J.; VAN WYK KOTZE, T.J. A comparision of fluoride release from various dental materials. J. Dent. v. 26, n. 3, p.259-65, Mar. 1998.

37 HEINTZE, S.D. A new material concept for inhibiting the formation of secondary caries. Amer. J. Dent. v. 12, n. special , p. S4-S7, Nov. 1999.

38 HICKEL, R. et al. New direct restorative materials. Int. dent. J. v. 48, n. 1, p.316, Feb. 1998.

39 ISMAIL, A.I. What is the effective concentration of fluoride? . Community. Dent. o. Epidem. v. 23, p. 246-251, 1995.

40 JAMES, R. Fluoride uptake and release from a glass ionomer J. dent. Res. v. 70, n. 4, p. $711,1991$.

41 JENKINS, G.N. Theories on the mode of action of fluoride in reducing dental decay. J. dent. Res. v. 49, n.1, p. 444-452, Jan-Jun. 1963 
42 KAN, K.C.; MESSER, L.B.; MESSER, H.H. Variability in cytotoxicity and fluoride release of resin-modified glass-ionomer cements J. dent. Res. v. 76, n. 8, p. 1502-1507, Aug. 1997.

43 KARANTAKIS, P. et al. Fluoride release from three glass ionomers, a compomer and a composite resin in water, artificial saliva and lactic acid. Oper. Dent. v.25, n.1, p. 20-25, Jan.-Feb. 2000

$44 \mathrm{KAWAI}, \mathrm{K}$. et al. In vitro enamel and cementum fluoride uptake from three fluoride-containing composites. Caries Res. v. 32, n. 6, p. 463-9, Nov.Dec.1998.

$45 \mathrm{KAWAI}, \mathrm{K}$. et al. In vitro dentine fluoride uptake from three fluoride-containing composites and their acid resistance. J. Dent. v.25, n.3-4, p.291-6, May-Jul. 1997.

46 KRAFT, U. et al. Fluoride release from restorative materials and artificial carieslike lesions. J. dent. Res. v. 77, n. 5, p. 1260, 1998.

47 LEVALLOIS et al. In vitro fluoride release from restorative materials in water versus artificial saliva medium (SAGF). Dent. Mat. v. 14, p. 441-447, Nov. 1998

48 MCCABE, J.F. Resin-modified glass-ionomers Biomaterials. v.19, p. 521-27, 1998

49 MJÖR, I.A. Glass-ionomer cement restoratioms and secondary caries: A preliminary report. Quintessence Int. v. 27, n. 3, p. 171-174, Mar. 1996. 
50 MODESTO, A. et al. Variglass fluoride release and uptake by an adjacent tooth. Amer. J. Dent. v. 10, n. 3, p. 123-7, Jun. 1997.

51 NARVAI, P.C. Cárie dentária e flúor: uma relação do século $X X$. Ciência e Saúde Coletiva v. 5, n. 2, p. 381-392, 2000.

52 OGAARD, B. et al. Fluoride level in saliva after bonding orthodontic brackets with a fluoride containing adhesive. Am. J. Orthodont. Dentofac. Orthop. v .111, n. 2, p. 199-202, Feb. 1997.

53 PRESTON, A.J. et al. Fluoride release from aesthetic dental materials. J. oral Rehab. v. 26, n. 2, p. 123-9, Feb. 1999.

54 REZK-LEGA, F.; OGAARD, B.; ROLLA,G. Availability of fluoride from glassionomer luting cements in human saliva Scand. J. dent. Res. v. 99, p. 60-63, 1991.

55 SHAW, A.J. et al. Fluoride release from glass ionomer and compomer materials 6-months data. J. Dent. v. 26, n. 4, p. 355-9, May 1998.

56 SMALL I.C.B. et al. Water sorption in resin-modified glass-ionomer cements: An vitro comparison with other materials. Biomaterials. v.19, p. 545-50, 1998.

57 STEINMETZ, M.J. et al. Rechargeability of fluoride releasing pit and fissure sealants and restorative resin composites. Amer. J. Dent. v. 10, n. 1, p. 3640, Nov. 1997. 
58 SULJAK, J.P.; HATIBOVIC-KOFMAN, S. A fluoride release-adsorption-release system applied to fluoride-releasing restorative materials. Quintessence Int. v.27, n. 9, p. 635-638, 1996.

59 SWIFT JÚNIOR, E.J. Floride release from two composites resins Quintessence Int. v. 20, n. 12, p. 895-897, 1989.

60 TAM, L.E.; CHAN, G. P-L; YIM, D. In vitro caries inhibition effects by conventional and resin-modified glass-ionomer restorations. Oper. Dent. v. 22, p. 4-13, 1997.

61 TAVES, O.R. Separation of fluoride by rapid diffusion using hexamethyldisiloxane. Talanta, v.15, p.969-74, 1968

62 TEN CATE, J.M. In vitro studies on the effects of fluoride on De- and Remineralization J. dent. Res. v.69, n. spec issue, p. 614-619, Feb., 1990.

63 VERBEECK, R.M. et al. Fluoride release process of (resin modified) glassionomers cements versus (poliacid-modified) composite resins. Biomaterials. v. 19, n. 6, p. 509-19, 1998.

64 VIEIRA, A.R.; SOUZA, I.P.R. DE; MODESTO, A. Fluoride uptake and release by composites and glass ionomers in a high caries challenge situation. Amer. J. Dent. v. 12, n. 1, Feb., 1999.

65 Vitremer TM - Ionômero de vidro de ativação tripla; perfil técnico do produto. s.I., 3M, 1994. 
$66 \mathrm{XU}, \mathrm{X}$. BURGESS, J.O. Fluoride release and compressive strenght of fluoride releasing materials. J. dent. Res. v. 77, p. 242, 1998.

67 WHITTERS, C.J. et al. Dental materials 1997: literature review. J. Dental. v. 27, n. 6, p. 401-35, Aug. 1999.

68 YAP,A.U.J.; KHOR,E.;FOO,S.H. Fluoride release and antibacterial properties of new-generation tooth-colored restoratives. Oper. Dent.. v.24,p.297-305, 1999.

69 YOUNG, A. et al. Fluoride release and uptake in vitro from a composite resin and two orthodontic adhesives. Acta odont. scand. v. 54, n. 4, p.223-8, Aug. 1996. 
ANEXOS 
ANEXO 1 - Quantidade diária de liberação de $\mathrm{F}$ em $\mu \mathrm{g} / \mathrm{mm}^{2}$, da resina composta Ariston em $\mathrm{H}_{2} \mathrm{O}$, em 24 horas, durante 15 dias.

\begin{tabular}{|c|c|c|c|c|c|c|c|c|c|}
\hline \multirow[b]{2}{*}{ dias } & \multicolumn{8}{|c|}{ Corpos - de-prova } & \multirow{2}{*}{$\begin{array}{l}\text { Médi } \\
\text { diári }\end{array}$} \\
\hline & 1 & 2 & 3 & 4 & 5 & 6 & 7 & 8 & \\
\hline 1 & 0,4437 & 0,1939 & 0,1996 & 0,4998 & 0,2824 & 0,2481 & 0,2007 & 0,3314 & 0,300 \\
\hline 2 & 0,1956 & 0,0939 & 0,1486 & 0,2276 & 0,1634 & 0,1645 & 0,9765 & 0,1805 & 0,268 \\
\hline 3 & 0,1855 & 0,1105 & 0,2141 & 0,1709 & 0,1466 & 0,1745 & 0,1253 & 0,1635 & 0,161 \\
\hline 4 & 0,1990 & 0,1532 & 0,2975 & 0,2146 & 0,2042 & 0,2699 & 0,1844 & 0,2020 & 0,215 \\
\hline 5 & 0,2243 & 0,2100 & 0,3676 & 0,2507 & 0,2475 & 0,3708 & 0,2465 & 0,2340 & 0,268 \\
\hline 6 & 0,1953 & 0,2329 & 0,3684 & 0,2241 & 0,2365 & 0,3335 & 0,2324 & 0,2231 & 0,255 \\
\hline 7 & 0,1973 & 0,1548 & 0,3329 & 0,2128 & 0,2231 & 0,3033 & 0,2165 & 0,2042 & 0,230 \\
\hline 8 & 0,2016 & 0,2325 & 0,3357 & 0,2170 & 0,2355 & 0,2988 & 0,1660 & 0,2003 & 0,235 \\
\hline 9 & 0,2082 & 0,2350 & 0,2371 & 0,2226 & 0,2381 & 0,2861 & 0,2355 & 0,2024 & 0,233 \\
\hline 10 & 0,2128 & 0,2571 & 0,3668 & 0,2315 & 0,2562 & 0,2818 & 0,2433 & 0,1602 & 0,251 \\
\hline 11 & 0,2342 & 0,2382 & 0,3468 & 0,2412 & 0,2438 & 0,2785 & 0,2265 & 0,2007 & 0,251 \\
\hline 12 & 0,2236 & 0,2347 & 0,3235 & 0,2357 & 0,2407 & 0,2613 & 0,2559 & 0,2167 & 0,249 \\
\hline 13 & 0,2184 & 0,2264 & 0,3134 & 0,2326 & 0,2407 & 0,2490 & 0,2357 & 0,1912 & 0,238 \\
\hline 14 & 0,2322 & 0,2448 & 0,3283 & 0,2538 & 0,2609 & 0,2664 & 0,2716 & 0,2009 & 0,257 \\
\hline 15 & 0,2353 & 0,2259 & 0,3228 & 0,2407 & 0,2338 & 0,2443 & 0,2308 & 0,2102 & 0,243 \\
\hline
\end{tabular}


ANEXO 2 - Quantidade diária de liberação de $\mathrm{F}$ em $\mu \mathrm{g} / \mathrm{mm}^{2}$, do CIV modificado por resina Vitremer em $\mathrm{H}_{2} 0$, em 24 horas, durante 15 dias

\begin{tabular}{cccccccccc}
\hline \hline dias & $\mathbf{1}$ & $\mathbf{2}$ & $\mathbf{3}$ & $\mathbf{4}$ & $\mathbf{5}$ & $\mathbf{6}$ & $\mathbf{7}$ & $\mathbf{8}$ & $\begin{array}{c}\text { médi } \\
\text { diári }\end{array}$ \\
\hline $\mathbf{1}$ & 0,6302 & 0,5655 & 0,6215 & 0,6663 & 0,7731 & 0,9949 & 0,6390 & 0,6037 & 0,686 \\
$\mathbf{2}$ & 0,2293 & 0,1995 & 0,2208 & 0,2325 & 0,2677 & 0,3137 & 0,2404 & 0,2339 & 0,242 \\
$\mathbf{3}$ & 0,1430 & 0,1272 & 0,1393 & 0,1505 & 0,1751 & 0,1713 & 0,1485 & 0,1517 & 0,150 \\
$\mathbf{4}$ & 0,1220 & 0,0932 & 0,1006 & 0,1163 & 0,1302 & 0,1523 & 0,1090 & 0,1116 & 0,116 \\
$\mathbf{5}$ & 0,0977 & 0,0825 & 0,0965 & 0,1014 & 0,1225 & 0,1339 & 0,0984 & 0,1012 & 0,104 \\
$\mathbf{6}$ & 0,0684 & 0,0615 & 0,0682 & 0,0708 & 0,0857 & 0,0967 & 0,0701 & 0,0702 & 0,074 \\
$\mathbf{7}$ & 0,0576 & 0,0474 & 0,0504 & 0,0538 & 0,0615 & 0,0743 & 0,0262 & 0,0539 & 0,053 \\
$\mathbf{8}$ & 0,0236 & 0,0406 & 0,0436 & 0,0464 & 0,0531 & 0,0652 & 0,0458 & 0,0493 & 0,046 \\
$\mathbf{9}$ & 0,0425 & 0,0382 & 0,0403 & 0,0435 & 0,0499 & 0,0600 & 0,0424 & 0,0457 & 0,045 \\
$\mathbf{1 0}$ & 0,0398 & 0,0367 & 0,0384 & 0,0415 & 0,0481 & 0,0634 & 0,0412 & 0,0422 & 0,043 \\
$\mathbf{1 1}$ & 0,0392 & 0,0362 & 0,0371 & 0,0392 & 0,0443 & 0,0575 & 0,0393 & 0,0416 & 0,041 \\
$\mathbf{1 2}$ & 0,0357 & 0,0331 & 0,0337 & 0,0370 & 0,0410 & 0,0520 & 0,0367 & 0,0370 & 0,038 \\
$\mathbf{1 3}$ & 0,0324 & 0,0308 & 0,0309 & 0,0335 & 0,0383 & 0,0505 & 0,0341 & 0,0344 & 0,035 \\
$\mathbf{1 4}$ & 0,0341 & 0,0314 & 0,0323 & 0,0356 & 0,0387 & 0,0494 & 0,0362 & 0,0367 & 0,036 \\
$\mathbf{1 5}$ & 0,0336 & 0,0312 & 0,0320 & 0,0448 & 0,0371 & 0,0463 & 0,0339 & 0,0381 & 0,037 \\
\hline \hline
\end{tabular}


ANEXO 3 - Quantidade diária de liberação de $\mathrm{F}$ em $\mu \mathrm{g} \% \mathrm{~mm}^{2}$, de resina composta modificada por poliácidos Dyract em $\mathrm{H}_{2} 0$, em 24 horas, durante 15 dias

\begin{tabular}{cccccccccc}
\hline \hline Dias & $\mathbf{1}$ & $\mathbf{2}$ & $\mathbf{3}$ & $\mathbf{4}$ & $\mathbf{5}$ & $\mathbf{6}$ & $\mathbf{7}$ & $\mathbf{8}$ & $\begin{array}{c}\text { médi } \\
\text { diári }\end{array}$ \\
\hline $\mathbf{1}$ & 0,0828 & 0,0856 & 0,0577 & 0,0417 & 0,0782 & 0,0414 & 0,0501 & 0,0554 & 0,061 \\
$\mathbf{2}$ & 0,0337 & 0,0467 & 0,0367 & 0,0288 & 0,0395 & 0,0306 & 0,0245 & 0,0285 & 0,033 \\
$\mathbf{3}$ & 0,0230 & 0,0328 & 0,0252 & 0,0162 & 0,0306 & 0,0159 & 0,0159 & 0,0237 & 0,022 \\
$\mathbf{4}$ & 0,0213 & 0,0305 & 0,0244 & 0,0131 & 0,0297 & 0,0127 & 0,0145 & 0,0222 & 0,021 \\
$\mathbf{5}$ & 0,0202 & 0,0267 & 0,0179 & 0,0101 & 0,0265 & 0,0107 & 0,0135 & 0,0176 & 0,017 \\
$\mathbf{6}$ & 0,0159 & 0,0184 & 0,0141 & 0,0084 & 0,0190 & 0,0086 & 0,0116 & 0,0135 & 0,013 \\
$\mathbf{7}$ & 0,0133 & 0,0016 & 0,0112 & 0,0070 & 0,0159 & 0,0072 & 0,0094 & 0,0117 & 0,009 \\
$\mathbf{8}$ & 0,0148 & 0,0163 & 0,0118 & 0,0077 & 0,0147 & 0,0089 & 0,0113 & 0,0130 & 0,012 \\
$\mathbf{9}$ & 0,0104 & 0,0121 & 0,0093 & 0,0063 & 0,0117 & 0,0063 & 0,0075 & 0,0102 & 0,009 \\
$\mathbf{1 0}$ & 0,0091 & 0,0108 & 0,0087 & 0,0057 & 0,0107 & 0,0059 & 0,0074 & 0,0093 & 0,008 \\
$\mathbf{1 1}$ & 0,0085 & 0,0110 & 0,0079 & 0,0058 & 0,0097 & 0,0057 & 0,0073 & 0,0086 & 0,008 \\
$\mathbf{1 2}$ & 0,0080 & 0,0088 & 0,0083 & 0,0056 & 0,0088 & 0,0056 & 0,0066 & 0,0081 & 0,007 \\
$\mathbf{1 3}$ & 0,0075 & 0,0086 & 0,0078 & 0,0055 & 0,0086 & 0,0058 & 0,0070 & 0,0079 & 0,007 \\
$\mathbf{1 4}$ & 0,0080 & 0,0087 & 0,0080 & 0,0057 & 0,0090 & 0,0066 & 0,0075 & 0,0082 & 0,007 \\
$\mathbf{1 5}$ & 0,0081 & 0,0081 & 0,0074 & 0,0054 & 0,0076 & 0,0055 & 0,0064 & 0,0072 & 0,007 \\
\hline \hline
\end{tabular}


ANEXO 4 - Quantidade diária de liberação de $\mathrm{F} \mathrm{em} \mu \mathrm{g} / \mathrm{mm}^{2}$, da resina composta Definite em $\mathrm{H}_{2} 0$, em 24 horas, durante 15 dias

\begin{tabular}{cccccccccc}
\hline \hline Dias & $\mathbf{1}$ & $\mathbf{2}$ & $\mathbf{3}$ & $\mathbf{4}$ & $\mathbf{5}$ & $\mathbf{6}$ & $\mathbf{7}$ & $\mathbf{8}$ & $\begin{array}{c}\text { médi } \\
\text { diáric }\end{array}$ \\
\hline $\mathbf{1}$ & 0,0012 & 0,0011 & 0,0010 & 0,0010 & 0,0010 & 0,0010 & 0,0011 & 0,0010 & 0,001 \\
$\mathbf{2}$ & 0 & 0,0007 & 0,0007 & 0,0007 & 0,0006 & 0,0006 & 0,0006 & 0,0007 & 0,000 \\
$\mathbf{3}$ & 0,0005 & 0,0001 & 0,0006 & 0,0005 & 0,0005 & 0,0005 & 0,0006 & 0,0006 & 0,000 \\
$\mathbf{4}$ & 0,0008 & 0,0007 & 0,0005 & 0,0006 & 0,0006 & 0,0006 & 0,0004 & 0,0004 & 0,000 \\
$\mathbf{5}$ & 0,0006 & 0,0005 & 0,0006 & 0,0003 & 0,0007 & 0,0007 & 0 & 0,0004 & 0,000 \\
$\mathbf{6}$ & 0,0006 & 0,0006 & 0,0002 & 0,0006 & 0,0006 & 0,0006 & 0,0007 & 0,0015 & 0,000 \\
$\mathbf{7}$ & 0,0006 & 0,0007 & 0,0005 & 0,0007 & 0,0005 & 0,0005 & 0,0005 & 0,0009 & 0,000 \\
$\mathbf{8}$ & 0,0036 & 0,0006 & 0,0012 & 0,0006 & 0,0017 & 0,0004 & 0,0004 & 0,0003 & 0,001 \\
$\mathbf{9}$ & 0,0003 & 0,0003 & 0,0002 & 0,0003 & 0,0024 & 0,0003 & 0,0005 & 0,0005 & 0,000 \\
$\mathbf{1 0}$ & 0,0004 & 0,0004 & 0,0004 & 0,0002 & 0,0002 & 0,0003 & 0,0003 & 0,0004 & 0,000 \\
$\mathbf{1 1}$ & 0,0006 & 0,0003 & 0,0003 & 0,0002 & 0,0005 & 0,0002 & 0,0003 & 0,0002 & 0,000 \\
$\mathbf{1 2}$ & 0,0011 & 0,0004 & 0,0002 & 0,0003 & 0,0003 & 0,0002 & 0,0002 & 0,0002 & 0,000 \\
$\mathbf{1 3}$ & 0,0003 & 0,0001 & 0,0002 & 0,0003 & 0,0002 & 0,0003 & 0,0002 & 0,0002 & 0,000 \\
$\mathbf{1 4}$ & 0,0031 & 0,0015 & 0,0003 & 0,0003 & 0,0004 & 0,0003 & 0,0003 & 0,0004 & 0,000 \\
$\mathbf{1 5}$ & 0,0001 & 0,0003 & 0,0006 & 0,0006 & 0,0003 & 0,0002 & 0,0003 & 0,0001 & 0,000 \\
\hline \hline
\end{tabular}


ANEXO 5 - Quantidade diária de liberação de $\mathrm{F}$ em $\mu \mathrm{g} / \mathrm{mm}^{2}$, da resina composta Tetric Ceram em $\mathrm{H}_{2} \mathrm{O}$, em 24 horas, durante 15 dias

\begin{tabular}{cccccccccc}
\hline \hline Dias & $\mathbf{1}$ & $\mathbf{2}$ & $\mathbf{3}$ & $\mathbf{4}$ & $\mathbf{5}$ & $\mathbf{6}$ & $\mathbf{7}$ & $\mathbf{8}$ & $\begin{array}{c}\text { médi } \\
\text { diári }\end{array}$ \\
\hline $\mathbf{1}$ & 0,0094 & 0,0098 & 0,0075 & 0,0055 & 0,0041 & 0,0118 & 0,0058 & 0,0027 & 0,007 \\
$\mathbf{2}$ & 0,0014 & 0,0021 & 0,0011 & 0,0015 & 0,001 & 0,0024 & 0,0009 & 0,0006 & 0,001 \\
$\mathbf{3}$ & 0,0005 & 0,0005 & 0,0003 & 0,0006 & 0,0005 & 0,0010 & 0,0006 & 0,0006 & 0,000 \\
$\mathbf{4}$ & 0,0004 & 0,0004 & 0,0006 & 0,0005 & 0,0004 & 0,0002 & 0,0005 & 0,0004 & 0,000 \\
$\mathbf{5}$ & 0,0004 & 0,0005 & 0,0006 & 0,0005 & 0,0004 & 0,0006 & 0,0004 & 0,0005 & 0,000 \\
$\mathbf{6}$ & 0,0006 & 0,0005 & 0,0005 & 0,0004 & 0,0003 & 0,0005 & 0,0003 & 0,0004 & 0,000 \\
$\mathbf{7}$ & 0,0003 & 0,0005 & 0,0005 & 0,0004 & 0,0003 & 0,0009 & 0,0004 & 0,0004 & 0,000 \\
$\mathbf{8}$ & 0,0004 & 0,0004 & 0,0004 & 0,0003 & 0,0002 & 0,0004 & 0,0004 & 0,0005 & 0,000 \\
$\mathbf{9}$ & 0,0003 & 0,0002 & 0,0004 & 0,0005 & 0,0002 & 0,0004 & 0,0003 & 0,0002 & 0,000 \\
$\mathbf{1 0}$ & 0,0002 & 0,0004 & 0,0001 & 0,0003 & 0,0001 & 0,0005 & 0,0004 & 0,0004 & 0,000 \\
$\mathbf{1 1}$ & 0,0004 & 0,0004 & 0,0006 & 0,0004 & 0,0005 & 0,0004 & 0,0003 & 0,0004 & 0,000 \\
$\mathbf{1 2}$ & 0,0003 & 0,0007 & 0,0004 & 0,0003 & 0,0003 & 0,0003 & 0,0002 & 0,0003 & 0,000 \\
$\mathbf{1 3}$ & 0,0003 & 0,0003 & 0,0004 & 0,0003 & 0,0002 & 0,0003 & 0,0003 & 0,0007 & 0,000 \\
$\mathbf{1 4}$ & 0,0004 & 0,0003 & 0,0006 & 0,0011 & 0,0003 & 0,0004 & 0,0001 & 0,0003 & 0,000 \\
$\mathbf{1 5}$ & 0,0006 & 0,0005 & 0,0003 & 0,0003 & 0,0015 & 0,0005 & 0,0001 & 0,0004 & 0,000 \\
\hline \hline
\end{tabular}


ANEXO 6 - Quantidade diária de liberação de $\mathrm{F}$ em $\mu \mathrm{g} / \mathrm{mm}^{2}$, da resina composta Z 100 em $\mathrm{H}_{2} \mathrm{O}$, em 24 horas, nos períodos de 1,7 e 15 dias

\begin{tabular}{cccccccccc}
\hline \hline & & \multicolumn{9}{c}{ Corpos-de-prova } & \multicolumn{1}{c}{ médii } \\
diária
\end{tabular}

ANEXO 7 - Quantidade diária de liberação de $\mathrm{F} \mathrm{em} \mu \mathrm{g} \% \mathrm{~mm}^{2}$, da resina composta Ariston em solução desmineralizante (DES-), durante 6 horas, por 15 dias

\begin{tabular}{|c|c|c|c|c|c|c|c|c|c|}
\hline \multirow[b]{2}{*}{ Dias } & \multicolumn{8}{|c|}{ Corpos-de-prova } & \multirow{2}{*}{$\begin{array}{l}\text { méd } \\
\text { diári }\end{array}$} \\
\hline & 1 & 2 & 3 & 4 & 5 & 6 & 7 & 8 & \\
\hline 1 & 0,2434 & 0,1558 & 0,1343 & 0,1617 & 0,1963 & 0,1406 & 0,2011 & 0,1245 & $0,16 \varsigma$ \\
\hline 2 & 0,1376 & 0,1195 & 0,1203 & 0,1019 & 0,1242 & 0,1182 & 0,1112 & 0,1137 & $0,11 \varepsilon$ \\
\hline 3 & 0,1147 & 0,1021 & 0,1046 & 0,1039 & 0,1057 & 0,1112 & 0,1098 & 0,1174 & $0,10 \varepsilon$ \\
\hline 4 & 0,0914 & 0,0990 & 0,0981 & 0,0971 & 0,0953 & 0,1042 & 0,1065 & 0,1152 & $0,10 C$ \\
\hline 5 & 0,0750 & 0,0711 & 0,0650 & 0,0840 & 0,0676 & 0,0611 & 0,0548 & 0,0611 & 0,067 \\
\hline 6 & 0,0662 & 0,0641 & 0,0560 & 0,0780 & 0,0614 & 0,0644 & 0,0633 & 0,0729 & 0,065 \\
\hline 7 & 0,0556 & 0,0610 & 0,0536 & 0,0719 & 0,0567 & 0,0602 & 0,0573 & 0,0625 & $0,05 \varsigma$ \\
\hline 8 & 0,0450 & 0,0477 & 0,0415 & 0,0558 & 0,0444 & 0,0457 & 0,0549 & 0,0481 & 0,047 \\
\hline 9 & 0,0459 & 0,0483 & 0,0418 & 0,0624 & 0,0450 & 0,0469 & 0,0470 & 0,0475 & $0,04 \varepsilon$ \\
\hline 10 & 0,0370 & 0,0396 & 0,0331 & 0,0465 & 0,0361 & 0,0375 & 0,0375 & 0,0381 & $0,03 \varepsilon$ \\
\hline 11 & 0,0336 & 0,0365 & 0,0293 & 0,0298 & 0,0329 & 0,0358 & 0,0333 & 0,0325 & $0,03 \approx$ \\
\hline 12 & 0,0290 & 0,0324 & 0,0281 & 0,0277 & 0,0295 & 0,0301 & 0,0290 & 0,0290 & $0,02 \varsigma$ \\
\hline 13 & 0,0302 & 0,0329 & 0,0278 & 0,0367 & 0,0314 & 0,0307 & 0,0308 & 0,0307 & 0,031 \\
\hline 14 & 0,0260 & 0,0274 & 0,0221 & 0,0310 & 0,0259 & 0,0252 & 0,0249 & 0,0226 & 0,025 \\
\hline 15 & 0,0262 & 0,0278 & 0,0236 & 0,0300 & 0,0274 & 0,0272 & 0,0273 & 0,0262 & $0,02\rceil$ \\
\hline
\end{tabular}


ANEXO 8 - Quantidade diária de liberação de $\mathrm{F}$ em $\mu \mathrm{g} / \mathrm{mm}^{2}$, do CIV modificado por resina Vitremer em solução desmineralizante (DES-), durante 6 horas, por 15 dias

\begin{tabular}{|c|c|c|c|c|c|c|c|c|c|}
\hline \multirow[b]{2}{*}{ Dias } & \multicolumn{8}{|c|}{ Corpos-de-prova } & \multirow{2}{*}{$\begin{array}{l}\text { méd } \\
\text { diári }\end{array}$} \\
\hline & 1 & 2 & 3 & 4 & 5 & 6 & 7 & 8 & \\
\hline 1 & 0,8575 & 0,6392 & 0,7669 & 0,9104 & 1,2257 & 0,6678 & 0,7589 & 0,7127 & \\
\hline 2 & 0,3142 & 0,2720 & 0,3090 & 0,3481 & 0,4203 & 0,2725 & 0,2920 & 0,2865 & 0,314 \\
\hline 3 & 0,2183 & 0,1823 & 0,2133 & 0,2359 & 0,3013 & 0,1870 & 0,2021 & 0,1974 & 0,217 \\
\hline 4 & 0,1588 & 0,1418 & 0,1663 & 0,1790 & 0,2455 & 0,1332 & 0,1549 & 0,1485 & $0,16 €$ \\
\hline 5 & 0,0891 & 0,0708 & 0,0875 & 0,1007 & 0,1470 & 0,0711 & 0,0848 & 0,0806 & 0,091 \\
\hline 6 & 0,0780 & 0,0595 & 0,0740 & 0,0834 & 0,1233 & 0,0654 & 0,0736 & 0,0672 & $0,07 \varepsilon$ \\
\hline 7 & 0,0775 & 0,0798 & 0,0856 & 0,0992 & 0,1324 & 0,0660 & 0,0785 & 0,0879 & $0,08 \varepsilon$ \\
\hline 8 & 0,0659 & 0,0498 & 0,0599 & 0,0667 & 0,0969 & 0,0501 & 0,0578 & 0,0565 & $0,06 \varepsilon$ \\
\hline 9 & 0,0626 & 0,0486 & 0,0592 & 0,0668 & 0,0943 & 0,0535 & 0,0624 & 0,0565 & $0,06=$ \\
\hline 10 & 0,0538 & 0,0431 & 0,0497 & 0,0554 & 0,0803 & 0,0457 & 0,0495 & 0,0502 & 0,05 \\
\hline 11 & 0,0473 & 0,0421 & 0,0480 & 0,0521 & 0,0712 & 0,0431 & 0,0479 & 0,0473 & $0,04 \varsigma$ \\
\hline 12 & 0,0468 & 0,0395 & 0,0450 & 0,0465 & 0,0657 & 0,0398 & 0,0424 & 0,0428 & $0,04 \epsilon$ \\
\hline 13 & 0,0508 & 0,0433 & 0,0505 & 0,0541 & 0,0688 & 0,0440 & 0,0474 & 0,0455 & $0,05 C$ \\
\hline 14 & 0,0441 & 0,0336 & 0,0426 & 0,0465 & 0,066 & 0,0376 & 0,0406 & 0,0374 & 0,04 \\
\hline 15 & 0,0512 & 0,0415 & 0,0463 & 0,0492 & 0,0649 & 0,0410 & 0,0464 & 0,0461 & $0,04 \varepsilon$ \\
\hline
\end{tabular}


ANEXO 9 - Quantidade diária de liberação de $\mathrm{F}$ em $\mu \mathrm{g} / \mathrm{mm}^{2}$, do compômero Dyract em solução desmineralizante (DES-), durante 6 horas, por 15 dias

\begin{tabular}{|c|c|c|c|c|c|c|c|c|c|}
\hline \multirow[b]{2}{*}{ Dias } & \multicolumn{8}{|c|}{ Corpos-de-prova } & \multirow{2}{*}{$\begin{array}{c}\text { méd } \\
\text { diári }\end{array}$} \\
\hline & 1 & 2 & 3 & 4 & 5 & 6 & 7 & 8 & \\
\hline 1 & 0,2368 & 0,1981 & 0,2110 & 0,1960 & 0,2348 & 0,2088 & 0,2603 & 0,2044 & $0,21 \varepsilon$ \\
\hline 2 & 0,0607 & 0,0553 & 0,0674 & 0,0538 & 0,0650 & 0,0667 & 0,0747 & 0,0660 & $0,06 \varepsilon$ \\
\hline 3 & 0,0434 & 0,0410 & 0,0520 & 0,0366 & 0,0457 & 0,0489 & 0,0543 & 0,0485 & $0,04 \epsilon$ \\
\hline 4 & 0,0383 & 0,0396 & 0,0468 & 0,0329 & 0,0424 & 0,0423 & 0,0461 & 0,0472 & $0,04 \varepsilon$ \\
\hline 5 & 0,0373 & 0,0392 & 0,0416 & 0,0402 & 0,0444 & 0,0371 & 0,0411 & 0,0442 & $0,04 \mathrm{C}$ \\
\hline 6 & 0,0524 & 0,0678 & 0,0611 & 0,0721 & 0,0606 & 0,0509 & 0,0534 & 0,0568 & $0,05 \subseteq$ \\
\hline 7 & 0,0501 & 0,0645 & 0,0571 & 0,0514 & 0,0580 & 0,0515 & 0,0508 & 0,0568 & 0,055 \\
\hline 8 & 0,0426 & 0,0476 & 0,0457 & 0,0408 & 0,0466 & 0,0426 & 0,0430 & 0,0449 & 0,044 \\
\hline 9 & 0,0450 & 0,0494 & 0,054 & 0,0483 & 0,0524 & 0,0495 & 0,0490 & 0,0514 & $0,04 \mathrm{c}$ \\
\hline 10 & 0,0365 & 0,0368 & 0,0408 & 0,0376 & 0,0413 & 0,0391 & 0,0361 & 0,0410 & $0,03 \varepsilon$ \\
\hline 11 & 0,0349 & 0,0353 & 0,0385 & 0,0356 & 0,0376 & 0,0360 & 0,0344 & 0,0375 & $0,03 \epsilon$ \\
\hline 12 & 0,0308 & 0,0325 & 0,0314 & 0,0288 & 0,0338 & 0,0319 & 0,0313 & 0,0318 & 0,031 \\
\hline 13 & 0,0306 & 0,0296 & 0,0323 & 0,0285 & 0,0342 & 0,0325 & 0,0311 & 0,0309 & 0,031 \\
\hline 14 & 0,0276 & 0,0277 & 0,0301 & 0,0258 & 0,0306 & 0,0291 & 0,0286 & 0,0260 & $0,02 \varepsilon$ \\
\hline 15 & 0,0276 & 0,0283 & 0,0314 & 0,0265 & 0,0308 & 0,0297 & 0,0278 & 0,0281 & $0,02 \varepsilon$ \\
\hline
\end{tabular}


ANEXO 10 -Quantidade diária de liberação de $\mathrm{F} \mathrm{em} \mu \mathrm{g} / \mathrm{mm}^{2}$, da resina composta Definite em solução desmineralizante (DES-), durante 6 horas, nos períodos de 1, 7 e 15 dias

\begin{tabular}{cccccccccc}
\hline \hline & & \multicolumn{7}{c}{ Corpos-de- prova } & méd \\
Dias & $\mathbf{1}$ & $\mathbf{2}$ & $\mathbf{3}$ & $\mathbf{4}$ & $\mathbf{5}$ & $\mathbf{6}$ & $\mathbf{7}$ & $\mathbf{8}$ & diári \\
\hline \hline $\mathbf{1}$ & 0,0034 & 0,0045 & 0,0033 & 0,0038 & 0,0029 & 0,0039 & 0,0026 & 0,0030 & $0,00 €$ \\
$\mathbf{7}$ & 0,0011 & 0,0008 & 0,0007 & 0,0008 & 0,0006 & 0,0006 & 0,0006 & 0,0006 & $0,00 C$ \\
$\mathbf{1 5}$ & 0,0005 & 0,0005 & 0,0005 & 0,0005 & 0,0005 & 0,0005 & 0,0004 & 0,0004 & $0,00 C$ \\
\hline \hline
\end{tabular}

ANEXO 11 -Quantidade diária de liberação de $\mathrm{F}$ em $\mu \mathrm{g} \% \mathrm{~mm}^{2}$, da resina composta Tetric Ceram em solução desmineralizante (DES-), durante 6 horas, nos períodos de 1, 7 e 15 dias

\begin{tabular}{cccccccccc}
\hline \hline & & \multicolumn{9}{c}{ Corpos-de-prova } & méd \\
Dias & $\mathbf{1}$ & $\mathbf{2}$ & $\mathbf{3}$ & $\mathbf{4}$ & $\mathbf{5}$ & $\mathbf{6}$ & $\mathbf{7}$ & $\mathbf{8}$ & diári \\
\hline \hline $\mathbf{1}$ & 0,0155 & 0,0152 & 0,0151 & 0,0119 & 0,0659 & 0,0171 & 0,0127 & 0,0511 & 0,025 \\
$\mathbf{7}$ & 0,0014 & 0,0011 & 0,0009 & 0,0009 & 0,0012 & 0,0008 & 0,0009 & 0,0009 & 0,001 \\
$\mathbf{1 5}$ & 0,0007 & 0,0007 & 0,0006 & 0,0005 & 0,0006 & 0,0006 & 0,0005 & 0,0006 & $0,00 C$ \\
\hline \hline
\end{tabular}

ANEXO 12 -Quantidade diária de liberação de $\mathrm{F}$ em $\mu \mathrm{g} \% \mathrm{~mm}^{2}$, da resina composta $Z 100$ em solução desmineralizante (DES-), durante 6 horas, nos períodos de 1, 7 e 15 dias

\begin{tabular}{cccccccccc}
\hline \hline & & \multicolumn{9}{c}{ Corpos-de- prova } & méd \\
Dias & $\mathbf{1}$ & $\mathbf{2}$ & $\mathbf{3}$ & $\mathbf{4}$ & $\mathbf{5}$ & $\mathbf{6}$ & $\mathbf{7}$ & $\mathbf{8}$ & diári \\
\hline \hline $\mathbf{1}$ & 0,0097 & 0,0029 & 0,0025 & 0,0029 & 0,0019 & 0,0027 & 0,0027 & 0,0044 & $0,00 \AA$ \\
$\mathbf{7}$ & 0,0015 & 0,0012 & 0,0010 & 0,0011 & 0,0011 & 0,0012 & 0,0011 & 0,0009 & 0,001 \\
$\mathbf{1 5}$ & 0,0009 & 0,0009 & 0,0008 & 0,0007 & 0,0007 & 0,0010 & 0,0007 & 0,0008 & $0,00 C$ \\
\hline \hline
\end{tabular}


TABELA 13 - Quantidade diária de liberação de $\mathrm{F}$ em $\mu \mathrm{g} / \mathrm{mm}^{2}$, da resina composta Ariston phc em solução remineralizante (RE), durante 18 horas, por 15 dias

\begin{tabular}{|c|c|c|c|c|c|c|c|c|c|}
\hline \multirow[b]{2}{*}{ Dias } & \multicolumn{8}{|c|}{ Corpos-de-prova } & \multirow{2}{*}{$\begin{array}{l}\text { méd } \\
\text { diári }\end{array}$} \\
\hline & 1 & 2 & 3 & 4 & 5 & 6 & 7 & 8 & \\
\hline 1 & 0,1417 & 0,2355 & 0,1439 & 0,0975 & 0,0327 & 0,1360 & 0,1512 & 0,0814 & 0,127 \\
\hline 2 & 0,1240 & 0,1278 & 0,1295 & 0,0536 & 0,1071 & 0,1230 & 0,1060 & 0,0265 & $0,09 \varsigma$ \\
\hline 3 & 0,1193 & 0,1186 & 0,1178 & 0,0273 & 0,1131 & 0,1145 & 0,1248 & 0,1417 & $0,10 \varsigma$ \\
\hline 4 & 0,0906 & 0,1121 & 0,1022 & 0,0141 & 0,0906 & 0,1065 & 0,1079 & 0,0190 & $0,08 C$ \\
\hline 5 & 0,0881 & 0,0912 & 0,0097 & 0,0301 & 0,0826 & 0,0966 & 0,0588 & 0,0312 & 0,061 \\
\hline 6 & 0,0894 & 0,0933 & 0,0882 & 0,1099 & 0,0877 & 0,0808 & 0,0920 & 0,1092 & $0,09 \varepsilon$ \\
\hline 7 & 0,0853 & 0,0824 & 0,0808 & 0,1009 & 0,0790 & 0,0902 & 0,0889 & 0,0984 & $0,08 \varepsilon$ \\
\hline 8 & 0,0789 & 0,0779 & 0,0935 & 0,0771 & 0,0860 & 0,0709 & 0,0927 & 0.0868 & $0,08 €$ \\
\hline 9 & 0,0750 & 0,0833 & 0,0748 & 0,0832 & 0,0742 & 0,0788 & 0,0801 & 0,0879 & $0,07 \varsigma$ \\
\hline 10 & 0,0260 & 0,0259 & 0,0240 & 0,0449 & 0,0712 & 0,0725 & 0,0740 & 0,0768 & 0,051 \\
\hline 11 & 0,0446 & 0,0686 & 0,0652 & 0,0313 & 0,0433 & 0,0715 & 0,0715 & 0,0692 & $0,05 \varepsilon$ \\
\hline 12 & 0,0631 & 0,0659 & 0,0626 & 0,0777 & 0,0655 & 0,0735 & 0,0669 & 0,0409 & 0,064 \\
\hline 13 & 0,0543 & 0,0580 & 0,0525 & 0,0681 & 0,0613 & 0,0665 & 0,0595 & 0,0622 & $0,06 C$ \\
\hline 14 & 0,0394 & 0,0600 & 0,0583 & 0,0694 & 0,0613 & 0,0637 & 0,0614 & 0,0637 & $0,05 \subseteq$ \\
\hline 15 & 0,0579 & 0,0398 & 0,0553 & 0,0665 & 0,0257 & 0,0617 & 0,0597 & 0,0619 & 0,05 \\
\hline
\end{tabular}


ANEXO 14 -Quantidade diária de liberação de $\mathrm{F}$ em $\mu \mathrm{g} \% \mathrm{~mm}^{2}$, do CIV Vitremer em solução remineralizante $(\mathrm{RE})$, durante 18 horas, por 15 dias

\begin{tabular}{|c|c|c|c|c|c|c|c|c|c|}
\hline \multirow[b]{2}{*}{ Dias } & \multicolumn{8}{|c|}{ Corpos-de-prova } & \multirow{2}{*}{$\begin{array}{l}\text { méd } \\
\text { diári }\end{array}$} \\
\hline & 1 & 2 & 3 & 4 & 5 & 6 & 7 & 8 & \\
\hline 1 & 0,4454 & 0,3857 & 0,5081 & 0,5326 & 0,8470 & 0,3743 & 0,4705 & 0,4665 & $0,50 €$ \\
\hline 2 & 0,1471 & 0,1282 & 0,1665 & 0,1719 & 0,2553 & 0,1218 & 0,1515 & 0,1412 & $0,16 C$ \\
\hline 3 & 0,0884 & 0,0630 & 0,1065 & 0,1145 & 0,1967 & 0,0815 & 0,1014 & 0,0942 & $0,10 \leftleftarrows$ \\
\hline 4 & 0,0646 & 0,0567 & 0,0661 & 0,0763 & 0,1158 & 0,0586 & 0,0635 & 0,0629 & $0,07 C$ \\
\hline 5 & 0,0490 & 0,0421 & 0,0492 & 0,0560 & 0,0769 & 0,0444 & 0,0457 & 0,0464 & 0,051 \\
\hline 6 & 0,0438 & 0,0364 & 0,0464 & 0,0562 & 0,0835 & 0,0160 & 0,0435 & 0,0505 & 0,047 \\
\hline 7 & 0,0454 & 0,0388 & 0,0461 & 0,0579 & 0,0658 & 0,0392 & 0,0453 & 0,0455 & $0,04 \varepsilon$ \\
\hline 8 & 0,0426 & 0,0372 & 0,0443 & 0,0531 & 0,0639 & 0,0380 & 0,0405 & 0,0434 & 0,045 \\
\hline 9 & 0,0399 & 0,0347 & 0,0420 & 0,0488 & 0,0568 & 0,0373 & 0,0417 & 0,0389 & $0,04 \varepsilon$ \\
\hline 10 & 0,0107 & 0,0125 & 0,0405 & 0,0483 & 0,0533 & 0,0359 & 0,0401 & 0,0387 & $0,03 E$ \\
\hline 11 & 0,0153 & 0,0184 & 0,0209 & 0,0151 & 0,0224 & 0,0103 & 0,0277 & 0,0166 & $0,01 \varepsilon$ \\
\hline 12 & 0,0149 & 0,0106 & 0,0085 & 0,0097 & 0,0238 & 0,0049 & 0,0207 & 0,0142 & $0,01 E$ \\
\hline 13 & 0,0103 & 0,0299 & 0,0370 & 0,0438 & 0,0434 & 0,0343 & 0,0359 & 0,0366 & $0,03 E$ \\
\hline 14 & 0,0356 & 0,0304 & 0,0388 & 0,0421 & 0,0476 & 0,0324 & 0,0351 & 0,0199 & 0,035 \\
\hline 15 & 0,0180 & 0,0324 & 0,0341 & 0,0457 & 0,0491 & 0,0319 & 0,0342 & 0,0356 & 0,035 \\
\hline
\end{tabular}


ANEXO 15 -Quantidade diária de liberação de $\mathrm{F}$ em $\mu \mathrm{g} / \mathrm{mm}^{2}$, do compômero Dyract em solução remineralizante $(\mathrm{RE})$, durante 18 horas, por 15 dias

\begin{tabular}{|c|c|c|c|c|c|c|c|c|c|}
\hline \multirow[b]{2}{*}{ Dias } & \multicolumn{8}{|c|}{ Corpos-de-prova } & \multirow{2}{*}{$\begin{array}{l}\text { méd } \\
\text { diári }\end{array}$} \\
\hline & 1 & 2 & 3 & 4 & 5 & 6 & 7 & 8 & \\
\hline 1 & 0,0220 & 0,0186 & 0,0188 & 0,0172 & 0,0198 & 0,0181 & 0,0255 & 0,0172 & $0,01 \mathrm{c}$ \\
\hline 2 & 0,0123 & 0,0106 & 0,0127 & 0,0097 & 0,0121 & 0,0123 & 0,0169 & 0,0115 & $0,01 \varepsilon$ \\
\hline 3 & 0,0123 & 0,0113 & 0,0146 & 0,0112 & 0,0135 & 0,0132 & 0,0181 & 0,0144 & $0,01 E$ \\
\hline 4 & 0,0115 & 0,0107 & 0,0144 & 0,0104 & 0,0127 & 0,0117 & 0,0163 & 0,0127 & 0,01 c \\
\hline 5 & 0,0139 & 0,0142 & 0,0171 & 0,0126 & 0,0157 & 0,0133 & 0,0173 & 0,0149 & 0,014 \\
\hline 6 & 0,0165 & 0,0185 & 0,0186 & 0,0159 & 0,0187 & 0,0156 & 0,0192 & 0,0177 & 0,017 \\
\hline 7 & 0,0171 & 0,0193 & 0,0189 & 0,0167 & 0,0183 & 0,0168 & 0,0205 & 0,0179 & $0,01 \varepsilon$ \\
\hline 8 & 0,0161 & 0,0177 & 0,0160 & 0,0162 & 0,0185 & 0,0170 & 0,0196 & 0,0180 & i \\
\hline 9 & 0,0161 & 0,0185 & 0,0192 & 0,0168 & 0,0190 & 0,0176 & 0,0210 & 0,0186 & $0,01 \varepsilon$ \\
\hline 10 & 0,0154 & 0,0160 & 0,0178 & 0,0152 & 0,0176 & 0,0157 & 0,0193 & 0,0177 & $0,01 \epsilon$ \\
\hline 11 & 0,0152 & 0,0160 & 0,0173 & 0,0149 & 0,0173 & 0,0159 & 0,0188 & 0,0183 & $0,01 \epsilon$ \\
\hline 12 & 0,0155 & 0,0160 & 0,0072 & 0,0149 & 0,0180 & 0,1570 & 0,0189 & 0,0184 & $0,03=$ \\
\hline 13 & 0,0141 & 0,0142 & 0,0163 & 0,0137 & 0,0165 & 0,0148 & 0,0164 & 0,0170 & 0,015 \\
\hline 14 & 0,0143 & 0,0142 & 0,0157 & 0,0146 & 0,0158 & 0,0141 & 0,0053 & 0,0162 & 0,018 \\
\hline 15 & 0,0133 & 0,0084 & 0,0155 & 0,0134 & 0,0159 & 0,0144 & 0,0159 & 0,0159 & 0,014 \\
\hline
\end{tabular}


ANEXO 16 -Quantidade diária de liberação de $\mathrm{F} \mathrm{em} \mu \mathrm{g} / \mathrm{mm}^{2}$, da resina composta Definite em solução remineralizante $(\mathrm{RE})$, durante 18 horas, nos períodos de 1, 7 e 15 dias

\begin{tabular}{cccccccccc}
\hline \hline & & \multicolumn{7}{c}{ Corpos-de-prova } & méd \\
Dias & $\mathbf{1}$ & $\mathbf{2}$ & $\mathbf{3}$ & $\mathbf{4}$ & $\mathbf{5}$ & $\mathbf{6}$ & $\mathbf{7}$ & $\mathbf{8}$ & diári \\
\hline \hline $\mathbf{1}$ & 0,0023 & 0,0006 & 0,0011 & 0,0010 & 0,0010 & 0,0010 & 0,0012 & 0,0007 & 0,001 \\
$\mathbf{7}$ & 0,0008 & 0,0007 & 0,0006 & 0,0008 & 0,0006 & 0,0005 & 0,0005 & 0,0005 & $0,00 C$ \\
$\mathbf{1 5}$ & 0,0010 & 0,0007 & 0,0006 & 0,0006 & 0,0005 & 0,0005 & 0,0005 & 0,0004 & $0,00 C$ \\
\hline \hline
\end{tabular}

ANEXO 17 -Quantidade diária de liberação de $\mathrm{F}$ em $\mu \mathrm{g} / \mathrm{mm}^{2}$, da resina composta Tetric Ceram em solução remineralizante (RE), durante 18 horas, nos períodos de 1, 7 e 15 dias

\begin{tabular}{cccccccccc}
\hline \hline & & \multicolumn{7}{c}{ Corpos-de-prova } & méd \\
Dias & $\mathbf{1}$ & $\mathbf{2}$ & $\mathbf{3}$ & $\mathbf{4}$ & $\mathbf{5}$ & $\mathbf{6}$ & $\mathbf{7}$ & $\mathbf{8}$ & diári \\
\hline \hline $\mathbf{1}$ & 0,0025 & 0,0018 & 0,0016 & 0,0012 & 0,004 & 0,0013 & 0,0012 & 0,0024 & $0,00 \epsilon$ \\
$\mathbf{7}$ & 0,0005 & 0,0006 & 0,0005 & 0,0005 & 0,0007 & 0,0007 & 0,0005 & 0,0005 & $0,00 C$ \\
$\mathbf{1 5}$ & 0,0005 & 0,0005 & 0,0004 & 0,0005 & 0,0005 & 0,0006 & 0,0005 & 0,0005 & $0,00 C$ \\
\hline \hline
\end{tabular}

ANEXO 18 -Quantidade diária de liberação de $\mathrm{F}$ em $\mu \mathrm{g} \% \mathrm{~mm}^{2}$, da resina composta $Z 100$ em solução remineralizante $(\mathrm{RE})$, durante 18 horas, nos períodos de 1, 7 e 15 dias

\begin{tabular}{cccccccccc}
\hline \hline & & \multicolumn{9}{c}{ Corpos-de-prova } & méd \\
Dias & $\mathbf{1}$ & $\mathbf{2}$ & $\mathbf{3}$ & $\mathbf{4}$ & $\mathbf{5}$ & $\mathbf{6}$ & $\mathbf{7}$ & $\mathbf{8}$ & diári \\
\hline \hline $\mathbf{1}$ & 0,0007 & 0,0006 & 0,0006 & 0,0005 & 0,0005 & 0,0006 & 0,0005 & 0,0007 & $0,00 \mathrm{C}$ \\
$\mathbf{7}$ & 0,0005 & 0,0005 & 0,0005 & 0,0005 & 0,0005 & 0,0005 & 0,0005 & 0,0005 & $0,00 \mathrm{C}$ \\
$\mathbf{1 5}$ & 0,0006 & 0,0005 & 0,0005 & 0,0005 & 0,0005 & 0,0005 & 0,0005 & 0,0006 & $0,00 \mathrm{C}$ \\
\hline \hline
\end{tabular}


ABSTRACT 


\section{ABSTRACT}

\section{Evaluation of the fluoride realease from composed resins in water and in $\mathrm{pH}$ - cycling system.}

The fluoride has an important function in the dental structure reducing the desmineralization and increase the remineralization. It is fundamental to know the behavior of the restoratives materials relative the fluoride release, not only in deionized water, but also in conditions of acid challenge. The aim of the present study was to determine the fluoride release from 6 restoratives materials, in two storage solutions: deionized water and pH-cycling system solution over 15 days. 16 discs (11 $\mathrm{mm}$ diameter and 1,5 $\mathrm{mm}$ thickness) of materials, Vitremer (VIT), Dyract (DYR), Ariston pHc (A), Tetric Ceram (TET), Definite (DEF) and Z 100 were prepared and suspended individually in $4 \mathrm{~mL}$ of each solution, in number of 8 for each medium which was changed every 24 hours. In the $\mathrm{pH}$-cycling system the specimens were immersed 6 hours in the demineralizing solution $(\mathrm{pH} 4,3)$ and 18 hours in remineralizing solution $(\mathrm{pH} 7,0)$. The solutions were changed daily during a period of 15 days. The fluoride release was determined after buffering the solutions with an equal volume of TISAB II. For the materials $Z$ 100, DEF, TET in deionized water, the fluoride concentration was obtained by the microdiffusion method (Taves) in the periods of 1,7 and 15 days. The analysis of the fluoride ion concentration in the solutions was measured using a fluoride ion sensitive electrode and a potentiometer ion-analyzer $\mathrm{pH} / \mathrm{F}^{-}$. The results of fluoride concentration in solutions were 
transformed into released fluoride amount per material area $\left(\mu \mathrm{gF}^{-} / \mathrm{mm}^{2}\right)$. All the materials released more fluoride in the $\mathrm{pH}$-cycling system, exception Ariston. The release peak was larger in the 1st day, dropped at the 2 nd and then remained constant from $7^{0}$ to 15 th day. The Ariston showed stable behavior, with small variations along the experiment. The results were submited to statistical analysis by ANOVA and the diferences between the treatments by the Tukey test $(p<0,05)$. In deionized water, fluoride release in $\mu \mathrm{gF}^{-} / \mathrm{mm}^{2}$ was $\mathrm{A}(3,6603)$, VIT(1,7529), DYR $(0,2481)$, TET $(0,0140)$, DEF $(0,0086)$ and $Z 100(0,0020)$ and, in pH-cycling system VIT (3,4366), A (2,1422), DYR (1,0691), TET (0,0297), Z $100(0,0067)$ and DEF $(0,0063)$, during the whole experimental period. 